\title{
Computer Assisted Orthopaedic and Trauma Surgery
}

Niels W.L. Schep 
Publication of this thesis was supported by:

Anna-Fonds Leiden

Arsis Medical

Johnson en Johnson

Mathys

Medivision

Medtronic

Nederlandse Vereniging van Traumatologie

Orthomed

Philips

Somas

Copyright@ 2003 By N.W.L. Schep

printed by:

Optima Grafische Communicatie Rotterdam

Afbeelding voorkant:

Messing sextant midden negentiende eeuw. Gebruikt voor maritieme navigatie.

Afbeelding achterkant: Droge kompasroos, H. Olland, Utrecht, naar een ontwerp van F.J. Kaiser.

Beide objecten maken deel uit van de collectie van het Maritiem Museum in Rotterdam

ISBN 30-6734-030-8 


\section{Computer Assisted Orthopaedic and Trauma Surgery}

Computer geassisteerde chirurgie in de orthopedie en de traumatologie

(met een samenvatting in het Nederlands)

\section{Proefschrift}

Ter verkrijging van de graad van doctor aan de Universiteit van Utrecht op gezag van de Rector Magnificus,

Prof.dr. W.H. Gispen,

Ingevolge het besluit van het college voor Promoties

In het openbaar te verdedigen op donderdag 16 oktober 2003 des middags te 14.30 uur

door

Niels Willem Luitzen Schep

Geboren op 22 januari 1972 te IJsselstein 

Promotor : Prof. Dr. Chr. van der Werken afdeling Heelkunde, Faculteit Geneeskunde, Universiteit Utrecht

\section{Co-promotor : Dr. I.A.M.J. Broeders}

afdeling Heelkunde, Faculteit Geneeskunde, Universiteit Utrecht 


\section{CONTENTS}

$\begin{array}{lll}\text { Chapter } 1 & \text { Introduction and aim of the thesis. } & 9\end{array}$

Chapter $2 \quad$ Computer assisted orthopedic and trauma surgery. 15

State of the art and future perspectives.

Injury $2003 ; 34: 299-306$.

Chapter 3 Validation of fluoroscopy based navigation in the hip region.

What you see is what you get?

Computer Aided Surgery $2002 ; 7: 279-283$.

Chapter $4 \quad$ Validation of computer assisted anteversion and length control

in closed nailing of femoral shaft fractures.

Submitted to Der Unfallchirurg.

Chapter $5 \quad$ Virtual planning of anterior cruciate ligament insertion.

Validation of a new technique.

Submitted to Arthroscopy.

Chapter 6 Internal fixation of femoral neck fractures with computer

assisted surgery.

A report on first cases.

European Journal of Trauma in press.

Chapter $7 \quad$ Computer assisted versus conventional surgery for insertion of

96 cannulated iliosacral screws.

Submitted to Journal of Trauma.

Chapter $8 \quad$ General discussion and conclusions

Samenvatting en conclusies

Dankwoord

Curriculum Vitae 


\section{Chapter}

\section{Introduction and aim of the thesis}

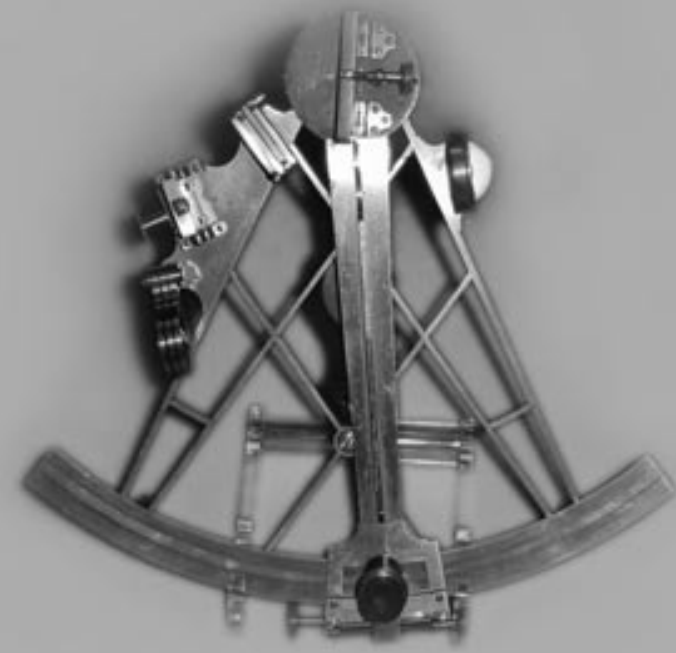




\section{Introduction}

When pilots land an airplane on a landing strip they depend for an important part on their direct eyesight for orientation. If bad whether conditions decrease their visibility they have to rely on their instruments for orientation in order to land safely. Minimal invasive trauma and orthopaedic surgery can be compared by flying in thick fog, because the surgeon performs the operation through small incisions. Consequently, direct sight on the operation area and therefore on their instrument position is impossible. In these situations surgeons must rely on radiographic imaging techniques like computer tomography (CT), magnetic resonance imaging (MRI) and fluoroscopy for orientation.

Drawback of these imaging techniques is that instrument positions are only shown at one particular moment, the moment of actual imaging. Continuous imaging is technically complex and leads to a significant radiation exposure for both patient and surgical team. ${ }^{(1-3)}$ In between imaging the surgeon has to rely on three-dimensional (3D) orientation and expert knowledge of the anatomy for instrument navigation. This situation may lead to inaccuracy and consequently operation related morbidity. Moreover, the lack of continuous visualisation may influence the reproducibility of surgical treatment, performing identical procedures.

To create an environment where surgeons receive real-time feedback about their instrument position, computer technologies were integrated in surgical procedures. This type of surgical technology is referred to as Computer Assisted Surgery (CAS). CAS offers the possibility to continuously monitor the position of surgical instruments in relation to the patient's anatomy intraoperatively. Therefore, the position of surgical instruments is superimposed virtually on single shot radiographic images in real time. This concept is analogous with a global positioning system (GPS) used for navigation. Pre- or intra-operatively obtained radiographic images act as the roadmap in which the position of a surgical instrument can be monitored virtually.

Potential advantages of CAS are improvement of accuracy and reproducibility of surgical procedures due to the fact that surgical instruments are guided by real time navigation. This may lead to less morbidity combined with a strong reduction of radiation exposure for both patient and surgical team.

The goal of this thesis was to evaluate the hypothesis of improved accuracy and reproducibility of surgical procedures using CAS. This was achieved by performing a series of tests. All these tests were performed within an experimental or clinical setting. To test the hypothesis the following questions were answered. 
1. How exact represents the displayed position of an instrument in fluoroscopic images the real situation?

2. Does CAS reduce surgical variance and therewith improve the reproducibility of (minimal invasive) orthopaedic and trauma surgery ?

3. Are there clinical benefits using CAS during positioning of implants? 
Introduction and aim of the thesis

\section{Reference List}

1. Madan, S. and Blakeway, C.: Radiation exposure to surgeon and patient in intramedullary nailing of the lower limb. Injury. 33:723, 2002.

2. Mehlman, C. T. and DiPasquale, T. G.: Radiation exposure to the orthopaedic surgical team during fluoroscopy: "how far away is far enough?". J. Orthop Trauma. 11:392-398, 1997.

3. Rampersaud, Y. R., Foley, K. T., Shen, A. C., Williams, S., and Solomito, M.: Radiation exposure to the spine surgeon during fluoroscopically assisted pedicle screw insertion. Spine. 25:2637-2645, 2000. 


\section{Chapter}

\section{Computer assisted orthopaedic and trauma surgery}

N.W.L. Schep, I.A.M.J. Broeders and Chr. van der Werken

Department of Surgery

University Medical Centre Utrecht, The Netherlands

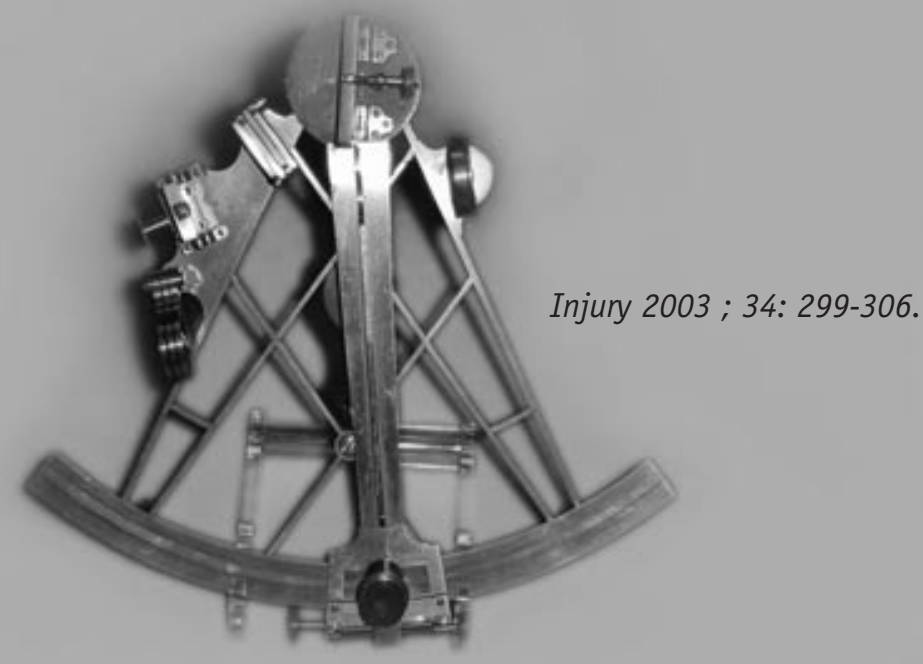




\section{Summary}

The recent years computer technologies are more and more integrated in surgical procedures. The potential advantages of computer assisted surgery (CAS) are: increase of accuracy of surgical interventions, less invasive operations, better planning and simulation and reduction of radiation exposure for both patient and surgeon. After introduction of CAS in neurosurgery, the clinical applications of this technique expanded also in trauma and orthopaedic surgery. The first application of this new technique in orthopaedic and trauma surgery was for placement of lumbar pedicle screws. After the introduction in spine surgery CAS was applied in other fields of orthopaedic surgery like hip, knee and skeletal trauma surgery. In this article the technical background and the various clinical applications of computer assisted orthopaedic and trauma surgery are outlined. 


\section{Introduction}

Computer technologies were introduced into surgical practice for preoperative planning and to enhance accuracy and safety for a variety of procedures. This new technology -so called Computer Assisted Surgery (CAS)- was initiated in neurosurgery and focused on preoperative planning and increased intra-operative accuracy. Neurosurgeons used this technique to facilitate intracranial needle biopsies, isotope implantation and tumor resection. $(1 ; 2 ; 10 ; 40 ; 45)$ For many years, only standard radiographic images including CT- and MRI- scans were used for preoperative planning. With the introduction of more complex surgical procedures, surgeons required better visualisation and manipulation of complex anatomy, pre- or intraoperatively, in an interactive way.

As part of CAS the surgeon is able to manipulate radiographic images during pre-operative planning. Subsequently, a link is made between the preoperative plan and the actual procedure. Technical adjustments of surgical instruments and the operating theatre enable surgeons to continuously monitor the position of instruments in relation to the patient's anatomy and the preoperative plan. Intra-operatively the position of the surgical instruments is superimposed in pre- or intra-operatively obtained images such as fluoroscopy, MRI- or CT scan.

The possible advantages are an increase in accuracy of surgical procedures due to "real time" navigation by a less invasive approach, less time-consuming interventions because of better planning and simulation and finally reduction of radiation exposure for both patient and surgeon.

An important problem during CAS is the continuous intra-operative change of anatomy caused by manipulation by the surgeon. Bone tissue, however, is almost not deformable and therefore is very suitable for CAS, based on pre- or intra-operatively obtained images. For this reason, after introduction of CAS in neurosurgery, the clinical applications of this technique expanded also in trauma and orthopaedic surgery. In this article the technical background and the various clinical applications of computer assisted orthopaedic and trauma surgery are outlined.

\section{Working with CAS}

CAS can be applied in the operating theatre only, but may be preceded by a preoperative workup, including planning and/or simulation. Preoperative planning is based on processing of available images such as CT and MRI scans. 3-D images are often computed at this stage 
of the procedure, and length or volumetric measurements may be conducted. With this information the surgeon can create a pre-operative plan for the optimal surgical procedure. This plan may be tested while simulating techniques, in which the skin incision, the approach to the target, the cut surfaces and the position of implants are evaluated. Simulation can also play an important role in training and education of residents and inexperienced surgeons. The image data, including the validated pre-operative workup are subsequently loaded on an $\mathrm{OR}$ workstation to enable image guided surgery exactly as planned. For routinely performed procedures, straightforward planning such as determination of entry points or access routes can be performed on the spot.

During CAS the position of the surgical instruments and the implants are displayed on a computer screen in relation to the patient's anatomy. For this purpose position tracking and registration are required. $(6 ; 8 ; 28 ; 43)$

\section{Instruments and position tracking}

The system can be compared with a global positioning system (GPS) used for automobile navigation. Here the surgical instrument is replaced by the car; the driver can see the virtual position of the car on a roadmap on a digital screen. In surgical navigation pre- or intraoperatively obtained digital radiographic images act as the roadmap.

A key element in surgical navigation is the tracking sensor, which identifies the instruments in order to determine their position. In the example of the GPS the tracking sensor is a satellite, which monitors the vehicle's position using signals transmitted by the navigation system in the car. Surgical tracking systems use magnetic, acoustic or optical signals for localising a target within the operating room. The most commonly used technique is optical tracking by (infrared) light emitting diodes (LEDs) or passive markers such as retro-reflective spheres or disks. Shields with at least two but usually four or six LEDs/passive markers are attached to the instruments and the operated bone. (Figure1)

To allow freedom of movement of the operation field during surgery, the position of the target bone also has to be tracked. Therefore, a frame with LEDs or passive markers is attached to the skeleton, the so-called dynamic reference frame (DRF). The tracking sensor overlooking the surgical field receives the signals emitted by the LEDs/passive markers of both the DRF and the surgical instruments. Subsequently the position of the instruments is superimposed on the radiographic images of the operated bone. (Figure 2 and 3) 

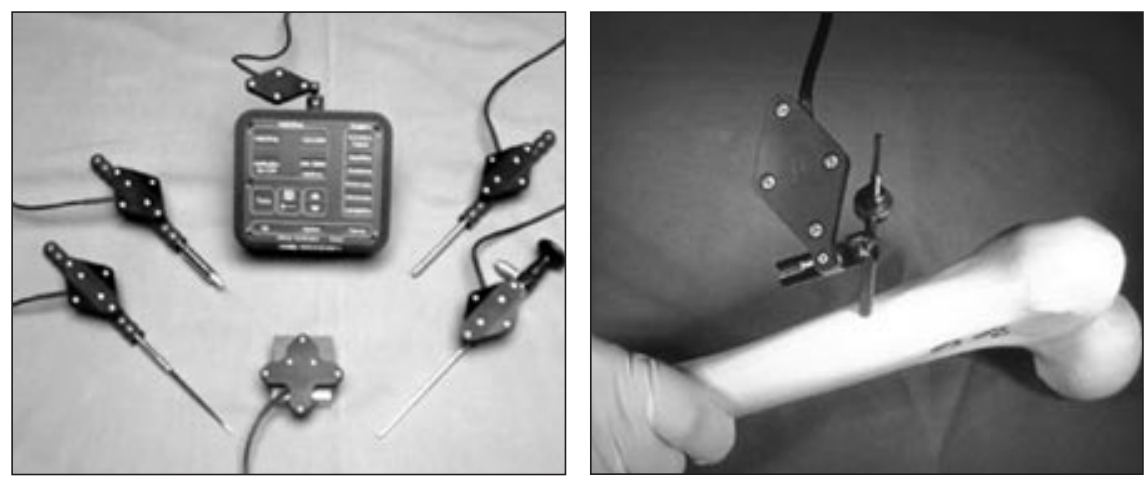

Figure 1

LEDs attached to surgical instruments and a dynamic reference frame (DRF) attached to a femur.

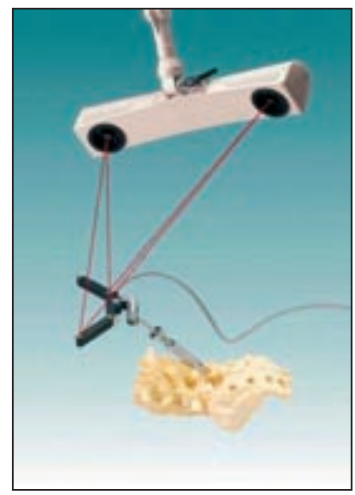

FIGURE 2

an optical tracker tracks the position of the target bone.

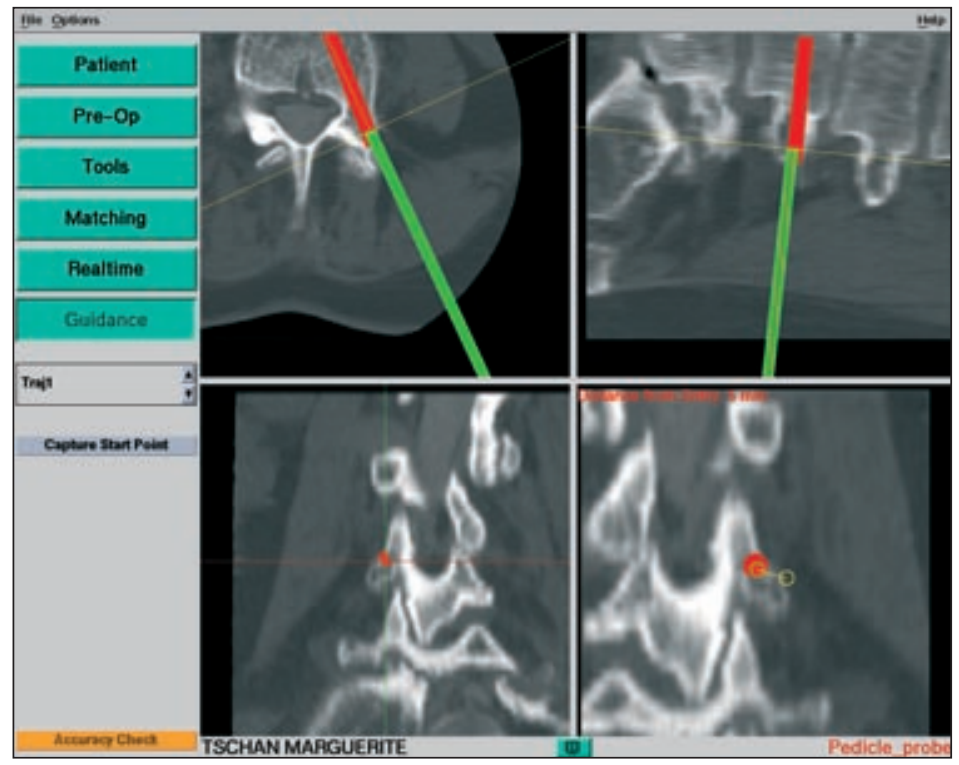

Figure 3

the position of the surgical instrument is superimposed in a pre-operative CT-scan of a vertebra in pedicle screw placement. 


\section{Registration of preoperatively obtained radiographic images}

The goal of registration is to establish a relationship between the current anatomy in the operating field and the anatomy displayed in pre-operative images. $\left({ }^{28}\right)$ This process requires an interactive computer system to match the co-ordinates of the preoperative images and the patient's anatomy.

The procedure can be roughly divided in two different kinds of techniques. In one, external markers in the other anatomic landmarks are used. After image acquisition the external markers on the patient are touched in a predefined order with a tracked instrument. In that way the position of an external marker is matched with its position on the pre-operative images. This registration method is very precise but the necessity of an additional operation for implanting the external markers is cumbersome. For this reason anatomical registration techniques were developed, based on recognition of anatomic details. Anatomic registration can be divided in paired point and surface registration. (Figure 4)

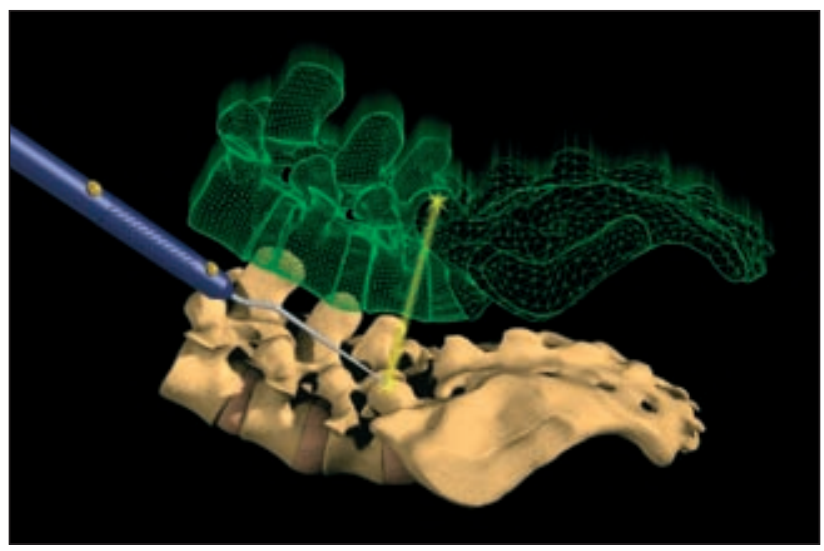

\section{Figure 4}

matching of an anatomical landmark with its co-ordinates in pre-operative images.

With paired point registration a 3-D localiser is used to touch well-defined anatomic landmarks on the bone surface. These landmarks are linked to the corresponding predefined landmarks on the images used. With Surface registration a random cluster of points is used instead of specific landmarks. ${ }^{28}$ ) (Figure 5 and 6 ) The computer uses a technique of trial and error to fit the touched bone surface area on the corresponding area of the 3D-reconstruction CT or MRI surface. $\left({ }^{37}\right)\left({ }^{28}\right)$ This procedure is faster than paired-point registration because a search for specific landmarks is not required. Another advantage is that the accuracy of surface matching is higher than anatomic surface matching because of the greater amount of digitized points. However, the bone surface should not be very flat or sphere-shaped, otherwise the matching is hampered by the lack of unique points. 


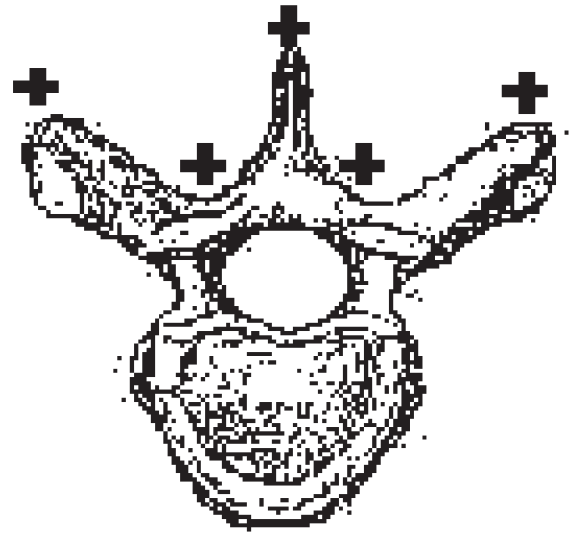

Figure 5

the processus spinosus, both processi transversus and a point in between are registered.

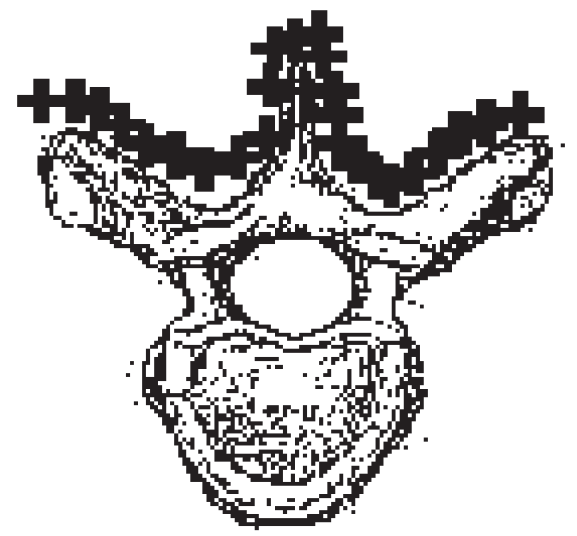

FiguRe 6

principles of surface matching.

Recently ultrasound has been introduced to obtain non-invasive surface registration. The position of the ultrasound probe is tracked and the collection of 3-D surface points is matched with a 3-D pre-operative CT or MRI image. $\left({ }^{41}\right)$

The latest development in non-invasive surface registration is the use of laser beams. The distance between a laser source and skin or exposed target surface is measured. The surgeon moves the laser over the surface of the target area, while a tracking sensor records the position of the laser source. In this way the system obtains a surface map of the collection of all laser points. Registration is done by matching the surface map to the surface of the 3-D model derived from existing images. (Figure 7)

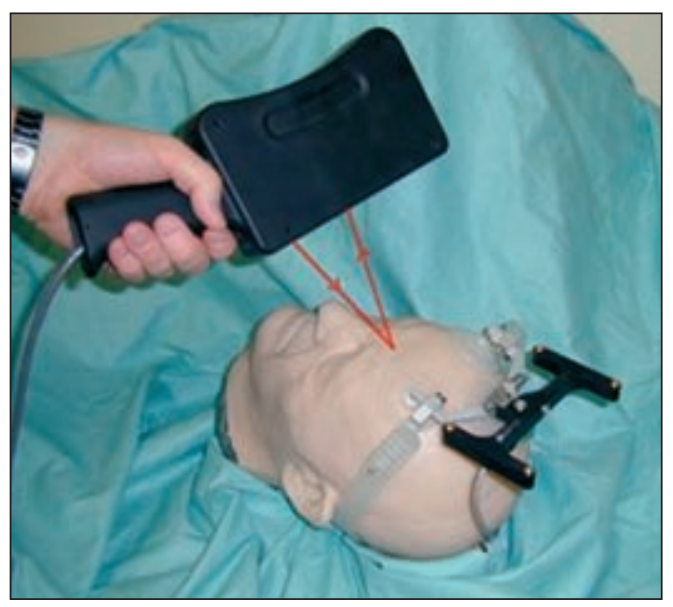

FIGURE 7

non-invasive surface registration with a laser 


\section{Navigation within intra-operatively obtained images}

When intra-operatively acquired images are used for navigation, a manual registration procedure can be avoided by tracking both the target and the imaging device. A sophisticated technique described by Jacob et al. is image-guided surgery with a CT scanner available in the operating room. While the patient is fixed firmly to the CT table, the position of the table relative to the CT scanner is recognized by the computer, providing exact orientation in targets fixed to the scanner table. An optical tracker attached to the ceiling above the CT scan detects the position of the instruments. Subsequently the position of the instruments is superimposed on the CT scans. $\left({ }^{15}\right)$ These procedures are also described with the use of MRI scans. $\left({ }^{3}\right)$

Generally however, fluoroscopy is used for navigation in intra-operatively acquired images. Advantages of this specific imaging modality are cost-effectiveness, general availability of C-arm systems, flexibility, ease of use and low radiation exposure. To combine fluoroscopy with navigation technology, the C-arm is equipped with a LED shield. This shield allows the $\mathrm{C}$-arm to be detected by the tracking sensor. $\left({ }^{14}\right)$ After image acquisition with the navigated $\mathrm{C}$-arm, the exact position of the tracked instruments is displayed in the fluoroscopy images. (Figure 8)

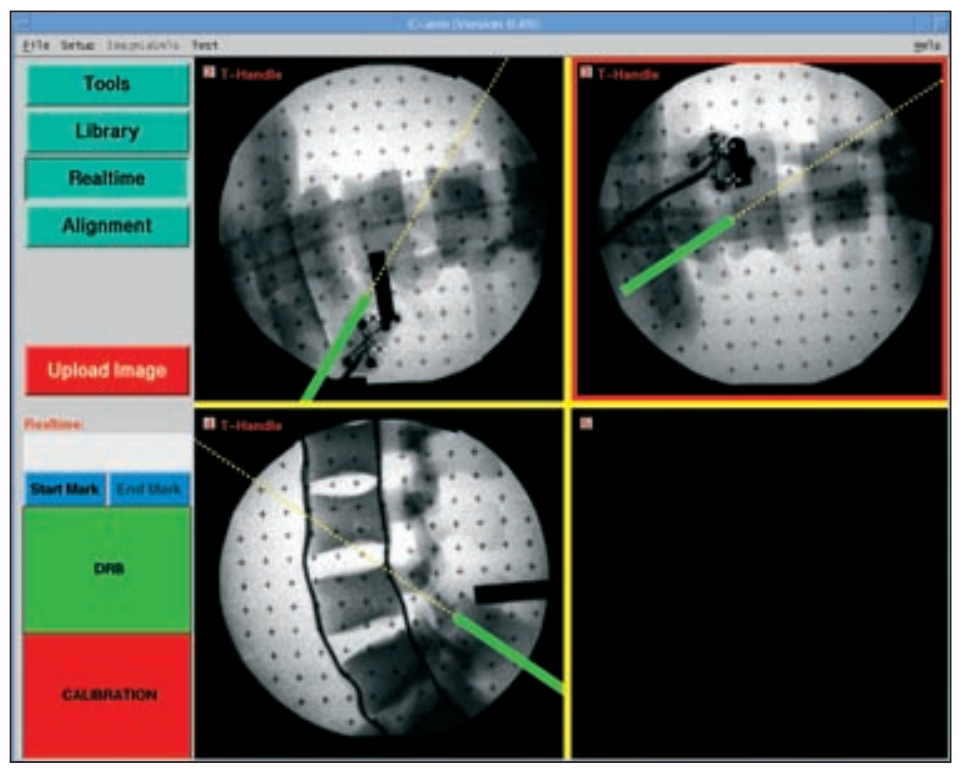

FigURE 8

the pedicle awl is displayed in fluoroscopic images of sawbone spine during pedicle screw placement. 


\section{Clinical applications of CAS}

The first application of CAS in orthopaedic and trauma surgery was for placement of lumbar pedicle screws. Transpedicle fixation is used in a variety of spine operations, including treatment of scoliosis, spondylolisthesis, fractures and instability. The rationale for using navigation technology in pedicle screw placement was an incidence of incorrect placement of the screws under fluoroscopy guidance, ranging from 10-40\%. $\left({ }^{27}\right)$ In 1995 Nolte et al. published an in vitro set up, drilling pedicle holes in lumbar vertebrae. The technique combined CT imaging with intra-operative navigation. For registration they used both surface and paired point matching. $\left({ }^{30}\right)$ Since 1995 many authors have reported clinical series on computer assisted CT based pedicle screw insertion. Schlenzka et al. assessed the accuracy of insertion of 139 screws by means of post-operative CT scans. With $133(95,7 \%)$ positioned in the pedicle. $\left({ }^{28: 35}\right)$ 0ther authors reported that CAS pedicle screw placement is an accurate, reproducible and safe procedure. The pedicle perforation rate in screws implanted with CAS ranges between $4-$ and $15 \%$. $\left({ }^{18 ; 22 ; 25-27 ; 36}\right)$

CAS pedicle screw placement with fluoroscopy based navigation is described by Nolte et al. for the first time. A prospective study to determine the accuracy of pedicle screw insertion using $\mathrm{C}$-arm based navigation was done by Fritsch et al. Of the 66 screws inserted, 63 $(95,5 \%)$ were placed within the pedicle wall. $\left({ }^{9 ; 2}\right)$ The good results in computer assisted pedicle screw placement helped introducing CAS in other fields of orthopaedic surgery.

In hip surgery, CAS is used to improve the clinical outcome of total hip replacement and periacetabular osteotomies. Dislocation after total hip replacement (THR) is a common postoperative complication. Malalignment of prosthetic components is responsible for a significant number of dislocations, with the acetabular cup being the most likely to be malpositioned. CAS can be used to facilitate the accuracy of acetabular cup implantation. $\left({ }^{7}\right)$

During preoperative planning implant size, location and cup orientation are specified in a digital 3-D model of the pelvis based on CT-scans. By means of simulating a range of motions the location and cup orientation are virtually tested. Subsequently the pre-operative plan is executed under image guidance. These image-guided systems offer improved methods of orientation measurement and cup placement during total hip replacement surgery. $\left({ }^{7 ; 12 ; 16}\right)$ Vandevelde et al. described a significant reduction in variability of abduction angles of the acetabular cup in favor of CAS when compared with conventional technique. $\left({ }^{42}\right)$

In 1997 Langlotz et al. presented the first 12 cases of computer assisted periacetabular osteotomies. This operation is used for the treatment of dysplastic hips and consists of a sequence of cuts performed through the ischium, pubis and ilium using different custom 
osteotomes and an oscillating saw. The acetabulum is completely liberated from the pelvis, reoriented and fixated. Preoperatively a CT scan of the complete pelvis was obtained. Registration was done by anatomical landmarks, fiducial markers or by surface matching. Al the surgical instruments were tracked by LED's. The correction was satisfactory in all hips with an improvement of the roof angle from $23.5^{\circ}$ to $7^{\circ}$. $\left({ }^{23 ; 24 ; 28}\right)$

In the knee CAS has been used in total knee arthroplasty (TKA) and knee ligament surgery. Proper rotational and translational alignment of the prosthetic components and the limb are key factors for the success of TKA and are therefore targets for navigation technology. $\left({ }^{44}\right)$ In general there are two CAS techniques for improving prosthetic alignment. One technique calculates the hip, knee and ankle centres by actively moving the optically tracked femur and tibia through a range of motions. The location of these centres provides the ideal mechanical axis of the tibia and femur. Subsequently, the position of the navigated cutting block is displayed relative to the desired position intra-operatively, so the surgeon is able to perform the bone resections of the distal femur and proximal tibia as planned pre-operatively. $\left({ }^{21}\right)$ The other CAS method uses 3-D computer models of the femur and tibia, constructed from preoperative CT-data. The computer calculates the bone resections that align the mechanical axis. Intra-operatively the procedure is as described above. $\left({ }^{4}\right)$

A prospective randomised trial comparing patients with computer assisted total knee arthroplasty and conventionally operated patients was performed by Saragaglia et al. $\left.{ }^{(33}\right)$ In both groups of 25 patients each, the postoperative femoro-tibial angle was measured. The femoro-tibial angle was between $177^{\circ}$ and $183^{\circ}$ in $75 \%$ of the patients operated with a conventional procedure and in $84 \%$ of the patients operated with CAS. The results in the computer-assisted group were better but not significantly different. A significant better result in mechanical axis in 100 computer assisted TKA patients compared to 50 conventionally operated patients was described by Kiefer et al. $\left({ }^{19}\right)$ The ideal mechanical axes were calculated when the optically tracked limb was moved through a range of motion. The postoperative mechanical axis in the coronal plane in the CAS group showed a mean deviation of $0.3^{\circ}$ varus, $73 \%$ were in the target range of $+/-2.0^{\circ}$, whereas only $40 \%$ of the patients reached this criteria in the conventionally operated group.

In reconstructive knee surgery navigation techniques are applied to improve the reproducibility of $\mathrm{ACL}$ graft placement. When the anterior cruciate ligament $(\mathrm{ACL})$ is disrupted an $\mathrm{ACL}$ graft is attached to the distal femur and proximal tibia. The problem is that reliable intra-articular landmarks for accurately positioning the graft hardly exist. This may result in malpositioning of the graft, resulting in impingement and non ideal elongation patterns.

Navigation systems can add pre- and intra-operative virtual reality feedback to ACL reconstruction. In that way the surgeon is able to determine the perfect femoral and 
tibial tunnels in order to avoid impingement. Several authors described computer assisted $\mathrm{ACL}$ replacement based on radiographic images. $\left({ }^{20 ; 31 ; 32}\right)$ These systems reduced the graft placement variability but did not offer the possibility of simulation under movement. Nonradiographic images based CAS in ACL reconstruction was presented by Dessenne et al. Two rigid dynamic reference bases (LED's) were attached to the femur and the tibia to track their positions. Predefined anatomical landmarks were digitised with a computer-integrated endoscopic palpation hook. Subsequently, the computer created a virtual model of the knee. Notch impingement for selected graft positioning could be predicted by displaying a virtual $\mathrm{ACL}$ before the actual drilling of the tunnels. This study showed that the use of computer systems offers the opportunity to individualise and optimise tunnel placement. (5;17;34) There are not yet enough clinical data at this moment to evaluate the place of computer assisted ACL reconstruction, but initial clinical results are promising.

In surgery for skeletal trauma exact reduction and placement of implants is required. Current clinical applications of navigation techniques in trauma surgery include; percutaneous iliosacral screw placement, percutaneous fixation of hip fractures and spine fractures. These operations can be performed with fluoroscopy or with CT based navigation. $\left({ }^{11 ; 4}\right)$ An appealing experimental example is computer assisted surgical stabilization (nailing) of long bone fractures. The position of the nail is superimposed on available radiographic images. This enables the surgeon to locate and reach the optimal insertion point in the bone. Alignment and the amount of rotation (anteversion) of the proximal and distal fracture parts is displayed on virtual reality images. The ability to visualise and correct the anteversion angle prevents rotational malalignment of the main fragments. $\left({ }^{13 ; 38}\right)$. An additional advantage is a strong decrease in the intra-operative fluoroscopy time when using computer assisted surgery for distal locking in intramedullary nailing. $\left({ }^{13 ; 14 ; 38}\right)$ Shum et al. compared fluoroscopic computer guidance with conventional distal locking of intramedullary nails and showed a reduction of inter-operative fluoroscopy time. The mean fluoroscopy time was 12 seconds in CAS and 168 seconds for conventional treated patients. The overall procedure time however was longer for the CAS method than with the free hand technique, 38 versus 25 min. $\left.{ }^{39}\right)$ 


\section{Reference List}

1. Apuzzo, M. L. and Sabshin, J. K.: Computed tomographic guidance stereotaxis in the management of intracranial mass lesions. Neurosurgery. 12:277-285, 1983.

2. Barnett, G. H., Kormos, D. W., Steiner, C. P., and Weisenberger, J.: Use of a frameless, armless stereotactic wand for brain tumor localization with two-dimensional and three-dimensional neuroimaging. Neurosurgery. 33:674-678, 1993.

3. Bernstein, M., Al Anazi, A. R., Kucharczyk, W., Manninen, P., Bronskill, M., and Henkelman, M.: Brain tumor surgery with the Toronto open magnetic resonance imaging system: preliminary results for 36 patients and analysis of advantages, disadvantages, and future prospects. Neurosurgery. 46:900-907, 2000.

4. Delp, S. L., Stulberg, S. D., Davies, B., Picard, F., and Leitner, F.: Computer assisted knee replacement. Clin. Orthop.49-56, 1998.

5. Dessenne, V., Lavallee, S., Julliard, R., Orti, R., Martelli, S., and Cinquin, P.: Computer-assisted knee anterior cruciate ligament reconstruction: first clinical tests. J. Image Guid. Surg. 1:59-64, 1995.

6. DiGioia, A. M.: What is computer assisted orthopaedic surgery? Clin. Orthop.2-4, 1998.

7. DiGioia, A. M., Jaramaz, B., Blackwell, M., Simon, D. A., Morgan, F., Moody, J. E., Nikou, C., Colgan, B. D., Aston, C. A., Labarca, R. S., Kischell, E., and Kanade, T.: The Otto Aufranc Award. Image guided navigation system to measure intraoperatively acetabular implant alignment. Clin. Orthop.8-22, 1998.

8. DiGioia, A. M., Jaramaz, B., and Colgan, B. D.: Computer assisted orthopaedic surgery. Image guided and robotic assistive technologies. Clin. Orthop.8-16, 1998.

9. Fritsch E., Duchow J. Seil R. Gruenwald I. Reith W. Intraoperative virtual fluoroscopy for placement of pedicle screws: accuracy of insertion. Computer Assisted Orthopaedic Surgery (CAOS), 1th annual meeting, Davos, Switzerland. 2001.

10. Gildenberg, P. L., Kaufman, H. H., and Murthy, K. S.: Calculation of stereotactic coordinates from the computed tomographic scan. Neurosurgery. 10:580-586, 1982.

11. Grutzner P.A., Vock B., Kowal.J., Nolte L.P., and Wentzensen A. Computer aided reduction and fixation of long bone fractures. Computer Assisted Orthopaedic Surgery (CAOS), 1th annual meeting, Davos, Switzerland. 2001.

12. Haaker R., Stockheim M. Rubenthaler F. Senge A. Wiese M. Accuracy of image guided hip cup placement. Computer Assisted Orthopaedic Surgery (CAOS), 1th annual meeting, Davos, Switzerland. 2001.

13. Hofstetter, R., Slomczykowski, M., Krettek, C., Koppen, G., Sati, M., and Nolte, L. P.: Computerassisted fluoroscopy-based reduction of femoral fractures and antetorsion correction. Comput. Aided Surg. 5:311-325, 2000.

14. Hofstetter, R., Slomczykowski, M., Sati, M., and Nolte, L. P.: Fluoroscopy as an imaging means for computer-assisted surgical navigation. Comput. Aided Surg. 4:65-76, 1999.

15. Jacob, A. L., Messmer, P., Kaim, A., Suhm, N., Regazzoni, P., and Baumann, B.: A whole-body registration-free navigation system for image-guided surgery and interventional radiology. Invest Radiol. 35:279-288, 2000.

16. Jaramaz, B., DiGioia, A. M., Blackwell, M., and Nikou, C.: Computer assisted measurement of cup placement in total hip replacement. Clin. Orthop.70-81, 1998.

17. Julliard, R., Lavallee, S., and Dessenne, V.: Computer assisted reconstruction of the anterior cruciate ligament. Clin. Orthop.57-64, 1998. 
18. Kamimura, M., Ebara, S., Itoh, H., Tateiwa, Y., Kinoshita, T., and Takaoka, K.: Accurate pedicle screw insertion under the control of a computer-assisted image guiding system: laboratory test and clinical study. J. Orthop. Sci. 4:197-206, 1999.

19. Kiefer H., Langemeyer D. Scherwitz U. Krause F. Computer aided knee arthroplasty versus conventional technique- first results. Computer Assisted Orthopaedic Surgery(CAOS), 1th annual meeting, Davos, Switzerland. 2001.

20. Klos, T. V., Habets, R. J., Banks, A. Z., Banks, S. A., Devilee, R. J., and Cook, F. F.: Computer assistance in arthroscopic anterior cruciate ligament reconstruction. Clin. Orthop.65-69, 1998.

21. Krackow, K. A., Bayers-Thering, M., Phillips, M. J., Bayers-Thering, M., and Mihalko, W. M.: A new technique for determining proper mechanical axis alignment during total knee arthroplasty: progress toward computer-assisted TKA. Orthopaedics. 22:698-702, 1999.

22. Laine, T., Schlenzka, D., Makitalo, K., Tallroth, K., Nolte, L. P., and Visarius, H.: Improved accuracy of pedicle screw insertion with computer-assisted surgery. A prospective clinical trial of 30 patients. Spine. 22:1254-1258, 1997.

23. Langlotz, F., Bachler, R., Berlemann, U., Nolte, L. P., and Ganz, R.: Computer assistance for pelvic osteotomies. Clin. Orthop.92-102, 1998.

24. Langlotz, F., Stucki, M., Bachler, R., Scheer, C., Ganz, R., Berlemann, U., and Nolte, L. P.: The first twelve cases of computer assisted periacetabular osteotomy. Comput. Aided Surg. 2:317-326, 1997.

25. Ludwig, S. C., Kramer, D. L., Balderston, R. A., Vaccaro, A. R., Foley, K. F., and Albert, T. J.: Placement of pedicle screws in the human cadaveric cervical spine: comparative accuracy of three techniques. Spine. 25:1655-1667, 2000.

26. Merloz, P., Tonetti, J., Eid, A., Faure, C., Lavallee, S., Troccaz, J., Sautot, P., Hamadeh, A., and Cinquin, P.: Computer assisted spine surgery. Clin. Orthop.86-96, 1997.

27. Merloz, P., Tonetti, J., Pittet, L., Coulomb, M., Lavallee, S., and Sautot, P.: Pedicle screw placement using image guided techniques. Clin. Orthop.39-48, 1998.

28. Nolte L.P, Ganz R. Computer Assisted Orthopaedic Surgery (CAOS). 1. 1998. Hogrefe \& Huber, Seatle Toronto Bern.

29. Nolte, L. P., Slomczykowski, M. A., Berlemann, U., Strauss, M. J., Hofstetter, R., Schlenzka, D., Laine, T., and Lund, T.: A new approach to computer-aided spine surgery: fluoroscopy-based surgical navigation. Eur. Spine J. 9 Suppl 1:S78-S88, 2000.

30. Nolte, L. P., Zamorano, L. J., Jiang, Z., Wang, Q., Langlotz, F., and Berlemann, U.: Image-guided insertion of transpedicular screws. A laboratory set-up. Spine. 20:497-500, 1995.

31. Petermann J., Ziring E. Heinze P. Krueger T. Heekt P. F. Gotzen L. Computer and robotic assisted acl reconstruction with CASPAR system. Computer Assisted Orthopeadic Surgery (CAOS), 1th annual meeting, Davos, Switzerland. 2001.

32. Picard, F., Moody, J. E., DiGioia, A. M., Martinek V., Fu F., Rytel M., Jaramaz, B., LaBarca R.S., and Nikou, C. Kneenav-acl computer assistedmeasuremnt reliability. Computer Assisted Orthopaedic Surgery (CAOS),1th annual meeting, Davos, Switzerland. 2001.

33. Saragaglia D., Picard F. Chaussard C. Montbarbon E. Leitner F. Cinquin P. Computer assisted total knee arthroplasty: comparison with a conventional procedure. Results of a 50 cases prospective randomized study. Computer Assisted Orthopaedic Surgery (CAOS), 1th annual meeting, Davos, Switzerland. 2001.

34. Sati, M. and Staubli H.U., B. Y. K. M.: Clinical integration of computer- assisted technology for arthroscopic anterior cruciate ligament reconstruction. Operative technques in Orthopaedics. 10: 40-49, 2000.

35. Schlenzka, D., Laine, T., and Lund, T.: Computer-assisted spine surgery. Eur. Spine J. 9 Suppl 1:S57-S64, 2000. 
36. Schwarzenbach, 0., Berlemann, U., Jost, B., Visarius, H., Arm, E., Langlotz, F., Nolte, L. P., and Ozdoba, C.: Accuracy of computer-assisted pedicle screw placement. An in vivo computed tomography analysis. Spine. 22:452-458, 1997.

37. Simon, D. A. and Lavallee, S.: Medical imaging and registration in computer assisted surgery. Clin. Orthop.17-27, 1998.

38. Slomczykowski, M. A., Hofstetter, R., Sati, M., Krettek, C., and Nolte, L. P.: Novel computer-assisted fluoroscopy system for intraoperative guidance: feasibility study for distal locking of femoral nails. J Orthop. Trauma. 15:122-131, 2001.

39. Suhm N., Jacob A. L. Zuna I. Roser H. W. Regazzoni P. Messmer P. Computer assisted distal locking of intramedullary implants: a controlled clinical study including 84 patients. Computer Assisted Orthopaedic Surgery (CAOS), 1th annual meeting, Davos, Switzerland. 2001.

40. Tan, K. K., Grzeszczuk, R., Levin, D. N., Pelizzari, C. A., Chen, G. T., Erickson, R. K., Johnson, D., and Dohrmann, G. J.: A frameless stereotactic approach to neurosurgical planning based on retrospective patient-image registration. Technical note. J. Neurosurg. 79:296-303, 1993.

41. Tonetti, J., Carrat, L., Lavallee, S., Pittet, L., Merloz, P., and Chirossel, J. P.: Percutaneous iliosacral screw placement using image guided techniques. Clin. Orthop.103-110, 1998.

42. Vandevelde D., Leenders T., Mahieu G., Nuyts R., and Verstreken J. Reduction in variability of acetabular cup position using computer assited surgery. Computer Assisted Radiology and Surgery (CARS) San Fransisco, USA. 2000.

43. Vannier, M. W. and Haller, J. W.: Navigation in diagnosis and therapy. Eur. J. Radiol. 31:132-140, 1999.

44. Wasielewski, R. C., Galante, J. 0., Leighty, R. M., Natarajan, R. N., and Rosenberg, A. G.: Wear patterns on retrieved polyethylene tibial inserts and their relationship to technical considerations during total knee arthroplasty. Clin. Orthop.31-43, 1994.

45. Watanabe, E., Watanabe, T., Manaka, S., Mayanagi, Y., and Takakura, K.: Three-dimensional digitizer (neuronavigator): new equipment for computed tomography-guided stereotaxic surgery. Surg. Neurol. 27:543-547, 1987. 
Chapter

\section{Validation of fluoroscopy based navigation in the hip region}

\section{What you see is what you get?}

N.W.L. Schep ${ }^{1}$, Th. van Walsum ${ }^{2}$, J.S. de Graaf ${ }^{1}$, I.A.M.J. Broeders ${ }^{1}$ and Chr.van der Werken ${ }^{1}$

${ }^{1}$ Department of Surgery

${ }^{2}$ Image Science Institute

University Medical Centre Utrecht, The Netherlands

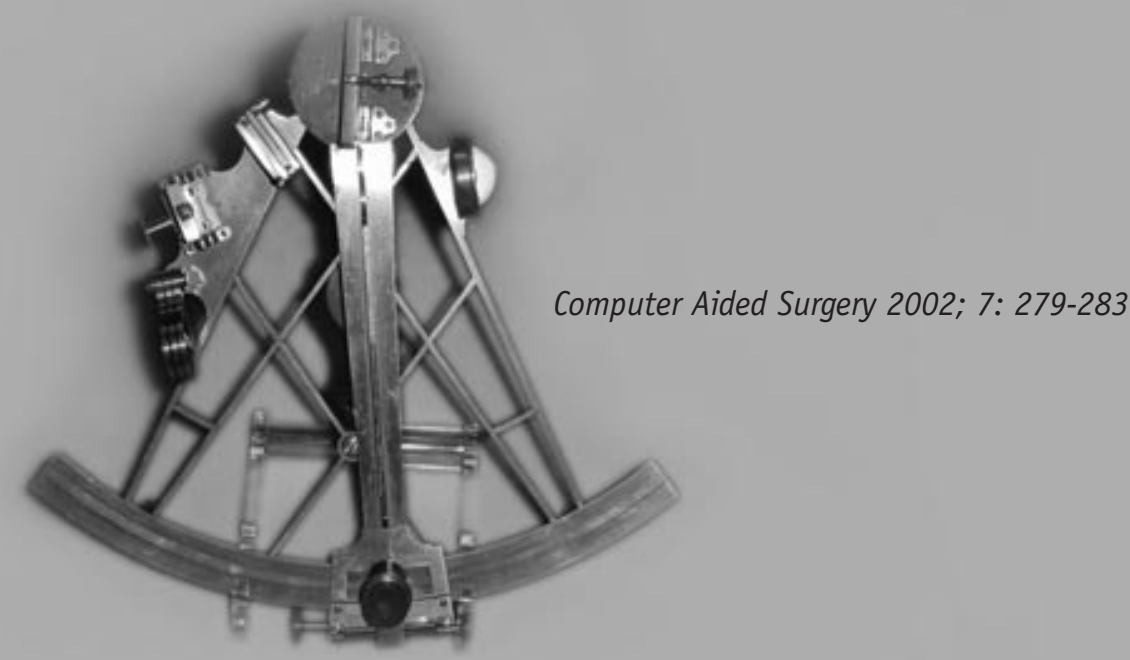




\section{Summary}

Objective: Fluoroscopy based navigation systems can be used for internal fixation of intracapsular femoral neck fractures, with the objective to optimise positioning of the implant and to reduce radiation exposure. With this technique the virtual position and direction of a reamer can be simultaneously superimposed on AP and axial AX fluoroscopic images. The objective of this study was to evaluate the accuracy of the displayed position of the virtual reamer in relation to the true position of the instrument when using a fluoroscopy based navigation system (Medivision, Oberdorf, Switserland). Secondary the accuracy of the drill channel measuring tool of the system was analysed.

Materials and Methods: The study was performed on 20 sawbones. To evaluate the position of the virtual reamer an $8 \mathrm{~mm}$ Perspex bar was inserted in predefined drill channels in each sawbone. AP and AX fluoroscopic images of the sawbones with the Perspex bar were loaded into the workstation. Next, the Perspex bar was removed and exchanged for a navigated dynamic hip screw (DHS) reamer. The position of the Perspex bar in the images represented the true position of the reamer. Subsequently, the difference between the position of the virtual reamer and the Perspex bar was measured with a dedicated computer program. Drill channel lengths measured with the system were compared with measurements obtained with a digital ruler.

Results: The mean difference in position of Perspex bar and reamer at a predefined point was $0.90 \mathrm{~mm}(0.00-3.21 \mathrm{~mm})$ in 360 images. The mean difference in length measurements between the Medivision system and the digital ruler was $1.00 \mathrm{~mm}$ ( $p=0.01$ std deviation $=1.33)$.

Conclusion: Reaming and measuring the screw channel of a DHS with a Medivision fluoroscopy based navigation system can be performed with an acceptable error margin. 


\section{Introduction}

The success of internal fixation of intracapsular femoral neck fractures is mainly determined by the quality of reduction and fixation. $\left({ }^{1-3}\right)$ Among the various treatment options the dynamic hip screw (DHS, A0-Synthes ${ }^{\circledR}$ ) is used in our centre for osteosynthesis of these fractures. In conventional surgery after reduction of the fracture, a K-wire is inserted to guide a reamer for drilling an insertion channel for the DHS.

Drawback of the current fluoroscopy techniques is that the positioning of the K-wire in the femoral neck and head can only be visualized in two-dimensional (2-D) projections. This leads to repetitive position changes of the $C$-arm, because both anteroposterior (AP) and axial (AX) images are required and makes the procedure prone to imperfect positioning of the K-wire, resulting in malpositioning of the implant. Moreover, interactive fluoroscopic guidance results in a substantial radiation exposure for both patients and surgical team. $\left(^{7}\right)$ Fluoroscopy based navigation may offer a solution to these problems. With this technique the virtual position and direction of the reamer can be simultaneously superimposed on AP and axial $A X$ fluoroscopic images. $\left({ }^{4-6}\right)$. Subsequently, the surgeon instantaneously drills the hole for the hip screw under navigation without the use of a K-wire.

Surgeons using this technique have to rely on the accuracy of the navigation system, since the only intraoperative feedback on the "true" position of reamer is the position of a virtual reamer superimposed on the fluoroscopic images. Lack of correspondence between the virtual position and the true position may lead to severe complications.

The mean objective of this study was to evaluate the accuracy of the displayed position of the virtual reamer in relation to the true position of the instrument when using a fluoroscopy based navigation system ( Medivision, Oberdorf, Switserland). The accuracy of the drill channel measuring tool of the system was also analysed.

\section{Materials and Methods}

All tests were performed on 20 sawbones (Synbone AG Davos, Switserland) in a laboratory setting.(Figure1) Drilling was performed directly with a specially developed non-canulated $8 \mathrm{~mm}$ DHS reamer, without the setup for plate reaming. A specially designed $135^{\circ}$ aiming device was used as a drill guide.(Figure 2) During drilling the virtual position of the DHS reamer was superimposed on the AP and AX images of the proximal femur and was displayed on the workstation (Medivision, Oberdorf, $\mathrm{CH}$.). 
Position tracking was performed with light emitting diodes and an opto-elektric camera ( Optotrak 3020 ${ }^{\circledR}$, Nothern Digital -inc, Waterloo, Canada). The C-arm (Philips BV 300-9 inch, Best, the Netherlands) was equipped with a shield holding 24 light emitting diodes (LEDs). The C-arm images were calibrated to compensate for the elastic deformation caused by the weight of the components of the $\mathrm{C}$-arm under gravity and the fluoroscope's image intensifier distortion $\left({ }^{5}\right)$. To maintain the relationship between the sawbone and the fluoroscopic images a shield with four LEDs, named the dynamic reference frame (DRF) was rigidly attached to the proximal part of the shaft of the sawbone before image acquisition. (Figure 1) LEDs were also attached to a compact air drive to track its position. (Figure 3)

First, $A P$ and $A X$ images were made and loaded in the workstation. ' $A X$ ' was defined as the projection where the axis of the femoral neck was exactly in line with the axis of the shaft of the femur. Subsequently, the $\mathrm{C}$-arm was rotated 90 degrees and the projection defined as 'AP' was obtained.

Before drilling, a length calibration of the non-canulated $8 \mathrm{~mm}$ DHS reamer had to be performed, the diameter of the reamer was also defined and stored in the system. During drilling the starting point at the lateral femoral cortex and the end point at the preferred position just below the femoral head cartilage were marked by pressing a footswitch. The drill channel length measurements, provided by the navigation system, were compared with true length measurements defined with a digital ruler (Helios, Niedernhall, Germany). This procedure was repeated in all 20 sawbones.

To evaluate the virtual position of the navigated DHS reamer, new AP and AX images were obtained with an $8 \mathrm{~mm}$ Perspex bar inserted in the predefined drill channel of each sawbone.(Figure 4) The position of the Perspex bar in these fluoroscopic images represented the true position of the reamer and therefore, acted as a reference. These images were loaded in the Medivision workstation. After image acquisition the Perspex bar was removed and exchanged for the navigated DHS reamer. On the workstation the virtual position of the DHS reamer was superimposed on the images containing the Perspex bar.

Next, the AP and AX images with and without the superimposed virtual reamer were transferred to a personal computer (Pentium III, 600 Mhz, 256MB) for measurements. (Figure 5) A dedicated computer program was developed to determine the centerlines and diameters of both Perspex bar and virtual reamer. Differences between the centerline position of the Perspex bar and the virtual reamer were determined in a standardized cut plane, outlined by a radiographic marker placed centrally over the femoral neck. This difference in position was defined as the positional error of the system in this test setup (|D-P|). (Figure 6) Additionally, the angles between the centerlines were determined. Position measurements 
Validation of fluoroscopy based navigation in the hip region

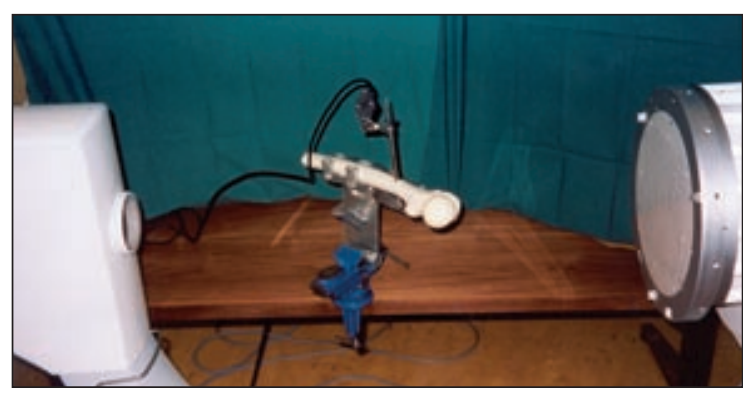

Figure 1

Laboratory setting, the dynamic reference frame (DRF) is clearly visible

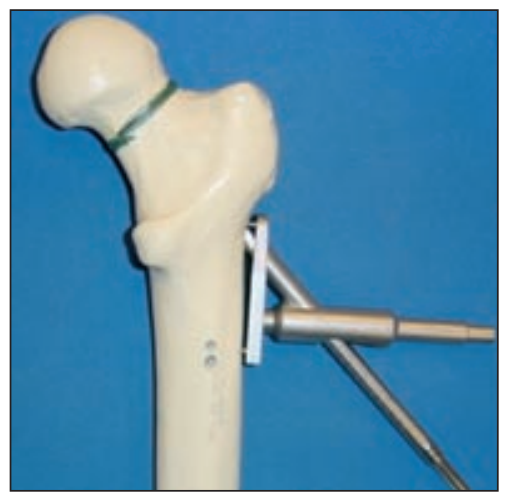

Figure 2

Sawbone with $135^{\circ}$ aiming device and non-cannulated $8 \mathrm{~mm}$ DHS reamer.

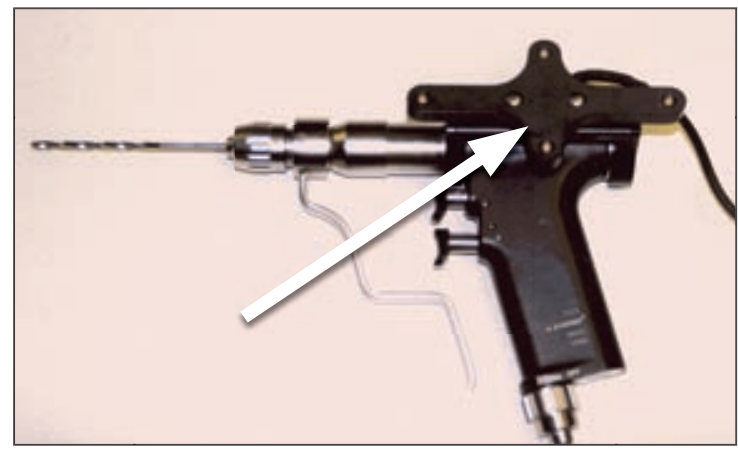

FIGURE 3

Navigated drill with LEDs attached.

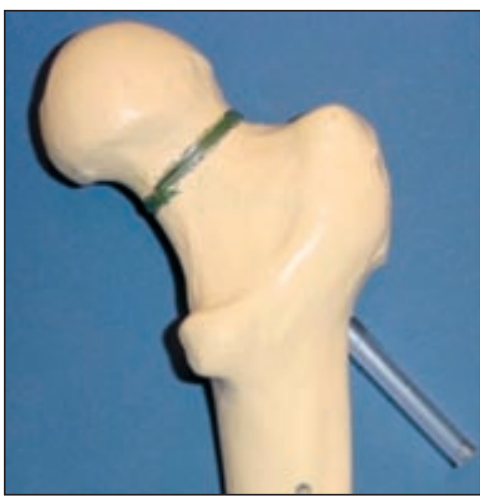

Figure 4

Positioning a Perspex bar in a predefined drill channel. 

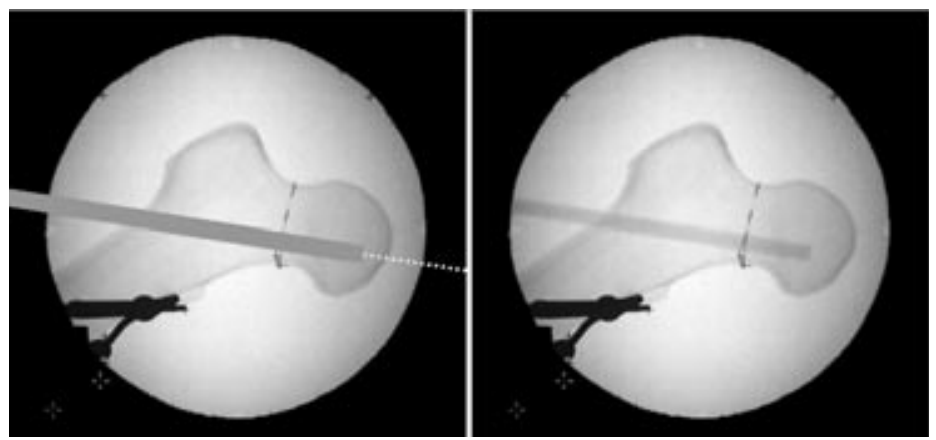

Figure 5

Captured AP images: Right image shows the Perspex bar, left image shows the navigated reamer, superimposed on the fluoroscopic image. Black line on femoral neck is radiographic marker that has been used to determine the cutplane.

in AP en AX images were accomplished after five different length calibrations, resulting in 200 measurements.

Intraoperatively it may be difficult to obtain accurate AP and $A X$ images therefore the influence of the $\mathrm{C}$-arm orientation, during image acquisition, on the accuracy of the virtual reamer position was also evaluated using the same methods. In every sawbone eight additional fluoroscopic images with the Perspex bar were obtained in angles of $90^{\circ}(\mathrm{AX})$, $80^{\circ}, 70^{\circ}, 60^{\circ}, 30^{\circ}, 20^{\circ}, 10^{\circ}$ and $0^{\circ}$ (AP). Again the difference in the centerline position between the Perspex bar and the virtual reamer was assessed for each angle in 160 images.

\section{Statistics}

All results were evaluated with SPSS 7.5 for Windows (SPSS, Inc, Chicago, USA). First the mean values of length measurements of the drill channels obtained with the navigation system and the digital ruler were evaluated. With a Wilcoxon signed- rank test the hypothesis was tested that no difference could be found between these populations.

The mean difference in position between the centerline position of the Perspex bar and virtual reamer was calculated out of a total of 360 measurements. Additionally the mean angle of the centerlines and the mean focal point was computed in all images.

To evaluate the relationship between the $\mathrm{C}$-arm angles and the error of the system, a scatterplot for $\mathrm{X}=\mathrm{C}$-arm angle and $\mathrm{Y}=|\mathrm{D}-\mathrm{P}|$ was drawn to evaluate the relationship between the $\mathrm{C}$-arm angles and the error of the system. Finally, a linear regression test was performed for these variables. 


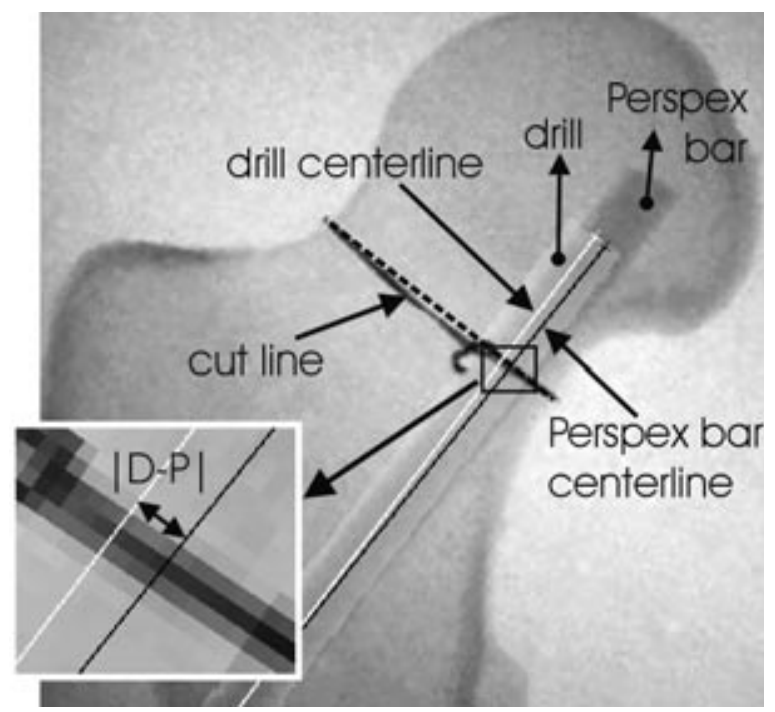

\section{Figure 6}

The centerlines of the Perspex bar and reamer are drawn in the images by the computer program. Difference in position of both center lines is displayed as $|D-P|$.

\section{Results}

The mean difference in length measurements of the drill channels between the Medivision system and the digital ruler was $1.00 \mathrm{~mm}(p=0.01$, std deviation $=1,33)$. In four sawbones the lengths, measured with the system appeared to be longer ( $\max .0,72 \mathrm{~mm}$ ) and in 15 bones the lengths appeared to be shorter (max. $4,48 \mathrm{~mm}$ ) than in reality.

The position of the centerlines showed a mean difference of $0.90 \mathrm{~mm}(0.00-3.21 \mathrm{~mm})$ in a total of 360 measurements at the predefined position in the femoral neck. In nine out of 360 measurements (2.5\%) this difference was more than $2 \mathrm{~mm}$. The mean angle between the centerlines was $0.39^{\circ}$ and the mean intersection of the centerlines point was $6 \mathrm{~cm}$ proximal of the cut line.

Linear regression analysis for the $\mathrm{C}$-arm orientation and $|\mathrm{D}-\mathrm{P}|$ showed a linear causal association with a regression coefficient -0.01 and $p<0.01$. (Figure 7) The mean difference in centerline position in AP images was $1.17 \mathrm{~mm}$ vs. $0.65 \mathrm{~mm}$ in AX images. (Table1) Independent samples T-test comparing the means of $|D-P|$ in the AP and AX images showed a significant difference with $p<0.01$. 


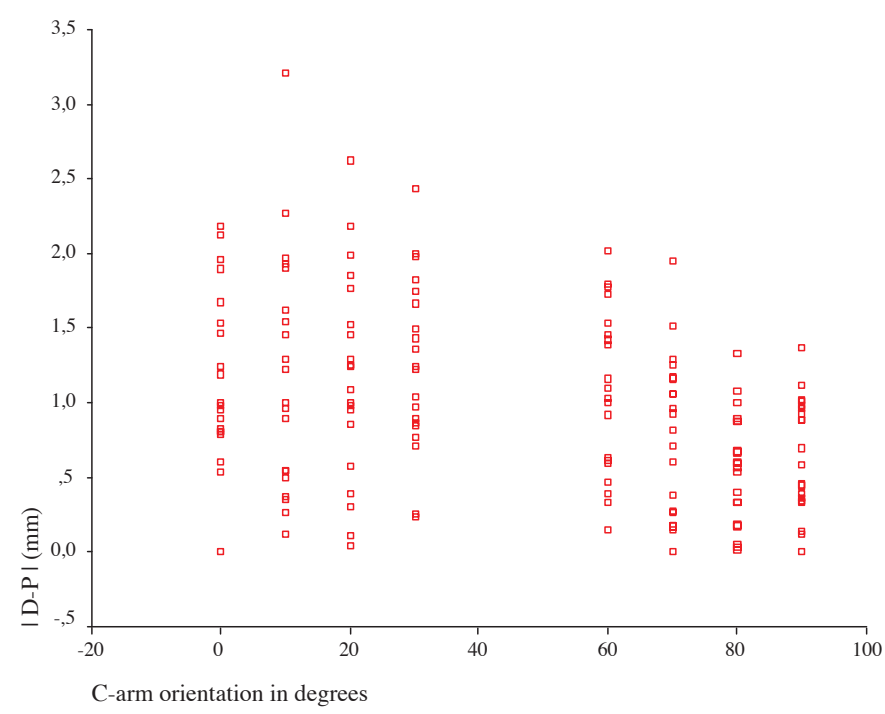

Figure 7

Scatterplot: $X=C$-arm angle and $Y=|D-P|$

TABLE 1

$\begin{array}{lccc}\text { C-arm orientation } & \text { N } & \text { Mean D-P | (mm) } & \text { Std.Deviation } \\ \mathrm{Ap} & 20 & 1,17436641 & 0.58000247 \\ 10^{\circ} & 20 & 1,20137107 & 0.79924296 \\ 20^{\circ} & 20 & 1,17542793 & 0.69496127 \\ 30^{\circ} & 20 & 1,25061356 & 0.58278411 \\ 60^{\circ} & 20 & 1,07772820 & 0.55373318 \\ 70^{\circ} & 20 & 0.79705981 & 0.52999684 \\ 80^{\circ} & 20 & 0.56382671 & 0.37377910 \\ \mathrm{AX} & 20 & 0.65380183 & 0.38322203\end{array}$

\section{Discussion}

The objective of this study was to evaluate the accuracy of the Medivision trauma module for drilling the screw channel for a DHS. First the length measuring tool of the navigation system was evaluated. In $75 \%$ of the cases virtual drill channel lengths measured with the system were shorter (mean $1 \mathrm{~mm}$ ) than the true channel length. In practice this means that in most cases undersized screws will be chosen. However, a mean difference of $1 \mathrm{~mm}$ is of no clinical relevance for this procedure. 
In addition to length measurements, this study focussed on positional errors of the virtual reamer, projected on single shot $A P$ and $A X$ images. In all experiments the difference in position between the virtual reamer and true position was measured in a predefined cutplane in the middle of the femoral neck We chose the clinically most relevant cutplane at the narrowest point of the calcar. The position of the virtual reamer appeared to be reliable in $97 \%$ of cases when considering an inaccuracy of $\leq 2 \mathrm{~mm}$ as clinically irrelevant. In nine out of 360 measurements a difference of more than $2 \mathrm{~mm}$ was found. In these cases it is most likely that the DRF was moved relative to the femur during the experiment, resulting in a loss of the relationship between the sawbone and the fluoroscopic images. This is an important pitfall in surgical navigation. Intra-operatively the surgeon has to monitor the fixation of the DRF. In case loss of rigid fixation is suspected it is obligatory to discontinue the procedure and to acquire new images.

Obviously, the parameter $|D-P|$ is dependent of the position of the cutplane chosen, in case the centerline of the Perspex bar and the centerline of the virtual reamer do not run parallel. However, the mean angle between these centerlines was $0.39^{\circ}$ with the intersection point at a mean distance of $6 \mathrm{~cm}$ ahead of the predefined measurement point. The inaccuracy, due to the deviation of the centerlines from the intersection point at the level of the femoral head will not lead to an unacceptable error.

Surprisingly, the accuracy of the virtual position of the reamer on 2-D fluoroscopy images appeared to be related to the angle of image acquisition. When the $\mathrm{C}$-arm was moved from $\operatorname{AX}\left(90^{\circ}\right)$ to $\operatorname{AP}\left(0^{\circ}\right)$, mean inaccuracy of the position of the virtual reamer increased.. Navigation based on AX fluoroscopic images appeared to be more accurate compared to navigation based on AP images. The $\mathrm{C}$-arm images are calibrated to compensate for the elastic deformation caused by the weight of the components of the $\mathrm{C}$-arm under gravity and the image intensifier distortion. A possible explanation for the difference in error between $\mathrm{AP}$ and $\mathrm{AX}$ images could be a difference in accuracy of $\mathrm{C}$-arm calibration in the extreme positions.

In conclusion, surgeons working with these systems have to realise that system inaccuracy consists of the sum of multiple errors. Sources of these errors are inaccuracy in position tracking by the opto-electric camera, in calibration of the C-arm, image distortion and in calibration of the drilling tool. However, the fluoroscopy based navigation system validated in this study provides a reliable virtual position of the reamer compared with the true situation when drilling the channel for a DHS. 


\section{Reference List}

1. Alberts KA, Jervaeus J. Factors predisposing to healing complications after internal fixation of femoral neck fracture. A stepwise logistic regression analysis. Clin Orthop 1990; 129-33.

2. Asnis SE, Wanek-Sgaglione L. Intracapsular fractures of the femoral neck. Results of cannulated screw fixation. J Bone Joint Surg Am 1994; 76: 1793-803.

3. Brown JT, Abrami G. Transcervical femoral fracture. J Bone Joint Surg 1964; 46B: 648-63.

4. Suhm N. Computer assisted distal locking of intramedullary implants: a controlled clinical study including 84 patients. Computer Assisted Orthopaedic Surgery (CAOS), 1th annual meeting, Davos, Switzerland. 2001.

5. Hofstetter R, Slomczykowski M, Sati M, Nolte LP. Fluoroscopy as an imaging means for computerassisted surgical navigation. Comput Aided Surg 1999; 4: 65-76.

6. Hofstetter R, Slomczykowski M, Krettek C, Koppen G, Sati M, Nolte LP. Computer-assisted fluoroscopybased reduction of femoral fractures and antetorsion correction. Comput Aided Surg 2000; 5: 31125.

7. Slomczykowski MA, Hofstetter R, Sati M, Krettek C, Nolte LP. Novel computer-assisted fluoroscopy system for intraoperative guidance: feasibility study for distal locking of femoral nails. J Orthop Trauma 


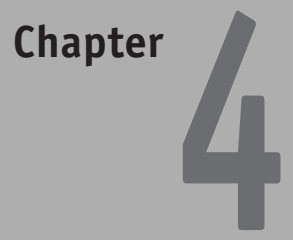

\section{Validation of computer assisted anteversion and length control in closed nailing of femoral shaft fractures}

N.W.L. Schep1, Th. van Walsum 2, M.H.J. Verhofstad1, E.J.M.Verleisdonk1

1 Department of Surgery

2 Image Science institute

University Medical Centre Utrecht, The Netherlands

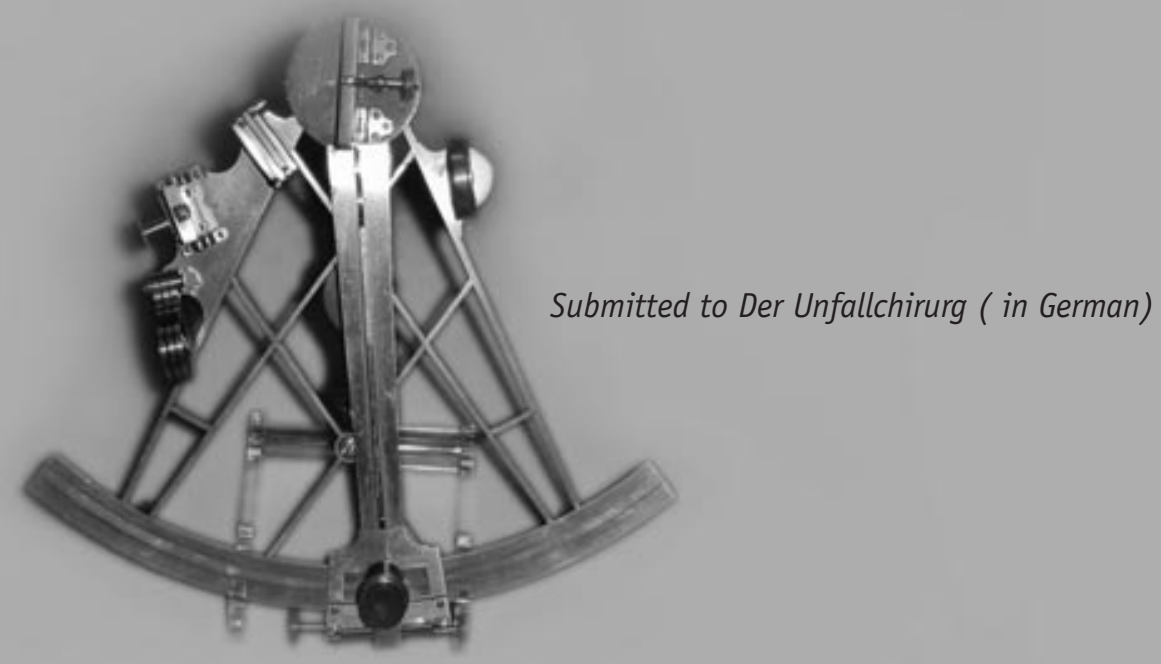




\section{Summary}

Objective: Computer Assisted Surgery (CAS) allows image guided femoral nailing and intraoperative control of rotation and length. The goal of this study was to evaluate the femoral anteversion angles and lengths provided by CAS in a cadaver study.

Material and Methods: Landmarks were manually defined in fluoroscopic images displayed on the CAS system to determine the anteversion and length of the femoral shaft. For evaluation, a golden standard based on CT data was developed. The CAS length and rotation values were compared with the CT-based ones. Inter-observer variability was assessed for both methods.

Results: Differences in length measurement between the CAS and CT based method were < $1 \mathrm{~cm}$. The variation in anteversion angles between the CAS and CT based method showed a mean difference of $13^{\circ}\left(\max .26^{\circ}\right)$. CAS inter-investigator variability was $5.5^{\circ}$ for anteversion and $5.2 \mathrm{~mm}$ for length. For the CT-based method this was $3.1^{\circ}$ for anteversion and $2.5 \mathrm{~mm}$ for length measurement.

Conclusion: Length measurements by the navigation system showed to be reproducible and accurate. The rotation measurements were reproducible with a mean difference of $5.5^{\circ}$ but not accurate enough to prevent malrotation. 


\section{Introduction}

Locked intramedullary nailing is commonly used for the treatment of femoral shaft fractures. For a limited invasive procedure the surgeon uses intraoperative fluoroscopy for nail insertion, fracture reduction and distal locking.

Drawback of this visualisation technique is the limitation to single two-dimensional (2-D) fluoroscopic projections. Repetitive position changes of the $\mathrm{C}$-arm are required to obtain both anteroposterior (AP) and axial (AX) images, resulting in substantial radiation exposure to both patient and surgical team. $\left({ }^{4 ; 5}\right)$ Moreover, this technique makes the procedure time consuming and may jeopardize sterility.

An important complication of the conventional nailing procedure is malrotation of the stabilised femur. Anteversion differences of $15^{\circ}$ or more are found in $19 \%$ and leg length discrepancies of more than $10 \mathrm{~mm}$ in $9 \%$ of the patients after operation. $\left({ }^{1 ; 2}\right)$

Recently, fluoroscopy based surgical navigation was introduced into surgical practice. This technique allows real time visualisation of surgical instruments superimposed into multiple single-shot fluoroscopic images. Hofstetter and others developed a computer-assisted surgery (CAS) module for the surgical treatment of femoral shaft fractures. $\left({ }^{3}\right)$ This concept allows image guided nail insertion, virtual alignment of bone fragments and intraoperative assessment and control of rotation and length. Potential advantages of this technique are reduction of radiation exposure, postoperative torsional deformities and leg length discrepancies.

The goal of this study was to evaluate the femoral anteversion angles and lengths provided by the navigation system (CAS) compared to a CT-based method (golden standard).

\section{Material and Methods}

\section{Operative procedure}

The experiments were performed in ten fresh cadaver legs. To allow fluoroscopy based surgical navigation, light emitting diodes (LED's) were attached to a C-arm (Philips BV 300, Best, The Netherlands) as well as to both femoral fracture fragments, the drilling machine and the nail insertion handle. An optical tracking sensor (Optotrak 3020 ${ }^{\circledR}$, Northern Digital-inc, Waterloo, Canada), overlooking the surgical field, received the infrared light emitted by the LED's for position tracking. The LED's attached to the fracture parts were referred to as dynamic reference frames (DRF's) to allow positional tracking of the fragments. (see figure 1). 

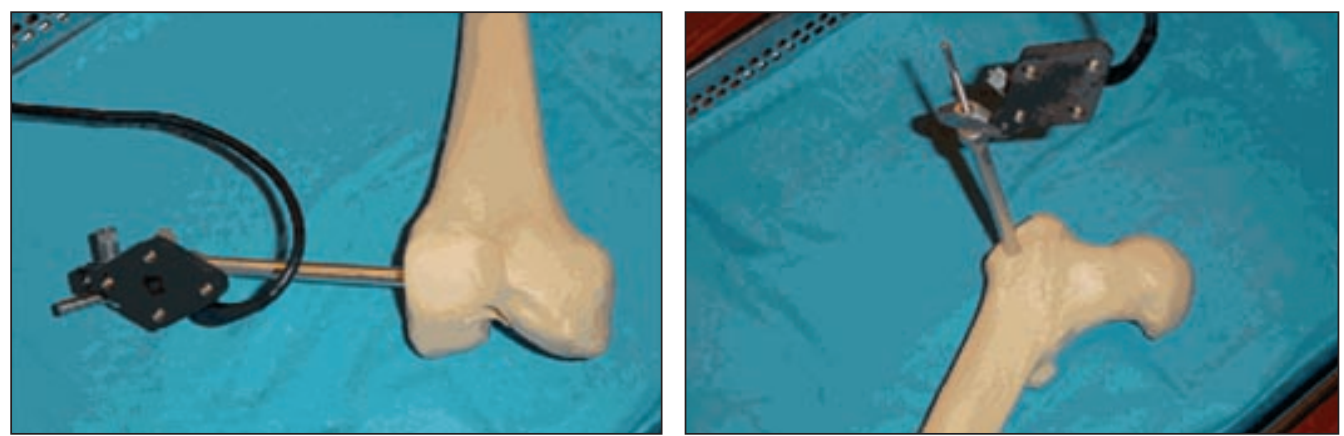

Figure 1

A dynamic reference frame (DRF) was attached to the proximal and distal femoral fragment. This allowed position tracking of both fracture parts.

Six fluoroscopic images of the proximal, middle (fractured) and distal part of the femur in an anteroposterior $(\mathrm{AP})$ and lateral $(\mathrm{AX})$ view were loaded into the navigation workstation (Medivision Surgigate ${ }^{\circledR}$, Oberdorf, Switzerland). To determine the rotation and length of the femoral shaft the following landmarks were manually defined in these images; the centre of the femoral head, the femoral neck axis, the distal and proximal fragment axis and the posterior and distal aspect of the condyles.

Based on these landmarks the anteversion angle (see figure 2) and the femoral length were calculated by the navigation system. Two lines on the fluoroscopic images represented the axis of the proximal and distal fragments. The bone axis was optimally reduced when the two lines were aligned in the AP and AX plane. (see figure 3).

First, the position of a $17 \mathrm{~mm}$ drillbit, equipped with LED's was superimposed on the AP and AX fluoroscopic images of the proximal femur. With help of the navigation system the optimal insertion point for an unreamed femoral nail (UFN, A0-Synthes ${ }^{\circledR}$, Umkirch, Germany) in the piriformis fossa was located and the cortex was opened.

Next, the nail was attached to the insertion handle (with LED's). The tip and proximal part of the nail were calibrated before insertion. During insertion the position of the nail tip and the proximal part of the nail were superimposed on the fluoroscopic images. Once the tip of the nail reached the fracture region, the fracture was reduced with the navigation system by aligning both virtual axes on the screen. Subsequently, the nail was passed into the distal fragment. (see figure 4)

Distal locking was performed by loading an additional AX fluoroscopic image, showing the distal locking holes with a maximum diameter, as a perfect circle. To position the drill in the locking hole a $4 \mathrm{~mm}$ drillbit was calibrated. Its virtual projection was superimposed in the additional fluoroscopic image, which enabled targeting. (see figure 5) 
Validation of computer assisted anteversion and length control in closed nailing of femoral shaft $\mathrm{fr}$

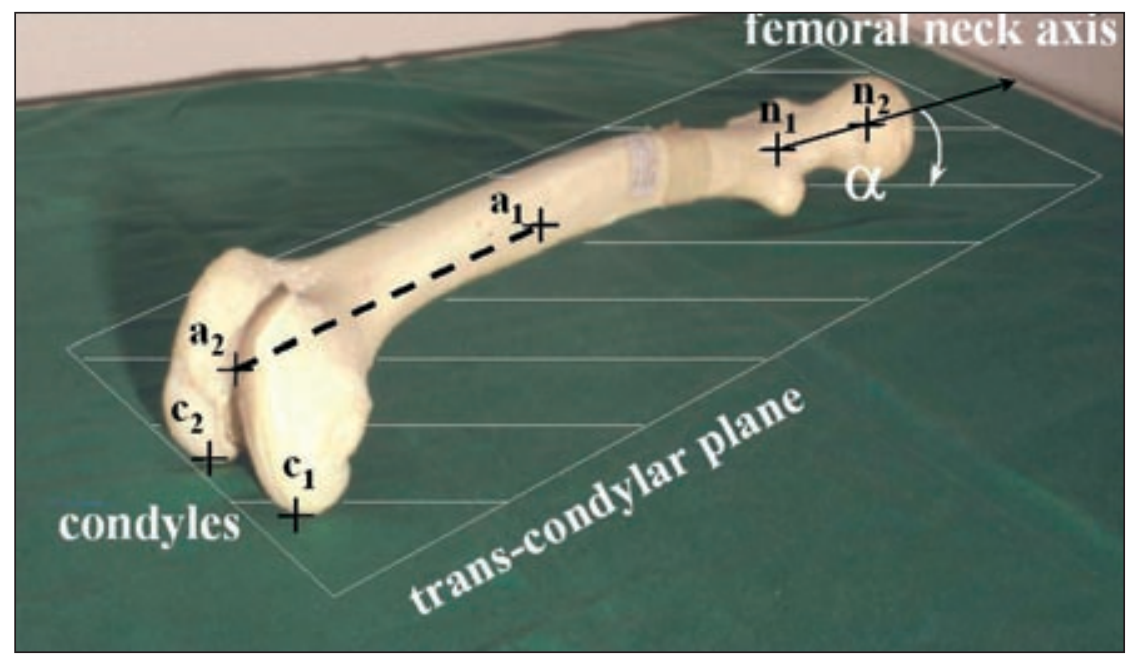

Figure 2

Definition of the femoral anteversion angle $\alpha$. This is the angle between the femoral neck axis and the trans-condylar plane and can be calculated using the landmarks $N_{1}, N_{2}, C_{1}, C_{2}, a_{1}, a_{2}$. Femoral length was defined by the centre of the femoral head and the distal condyles

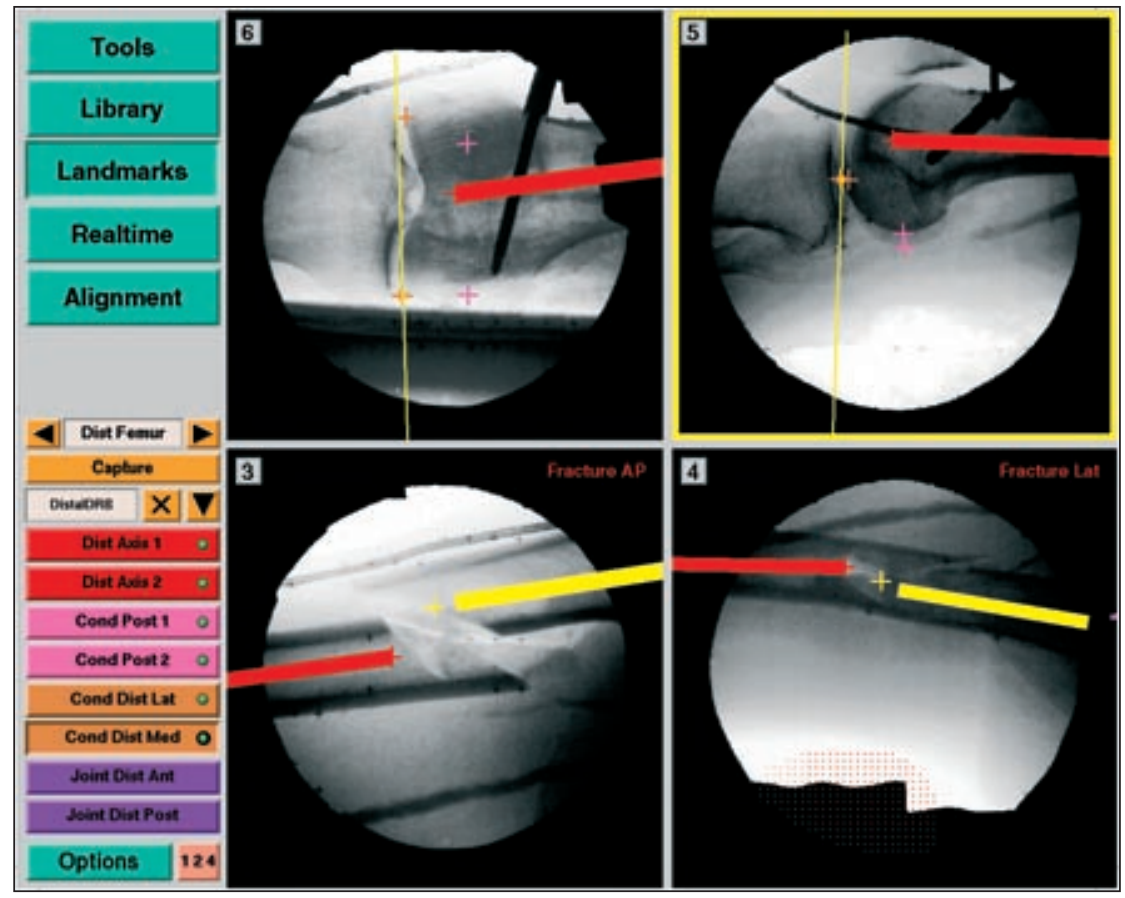

Figure 3

Two virtual axis represent the proximal and distal medullar canal. The bone axis was optimally reduced when the two lines were aligned in the AP and AX plane. 


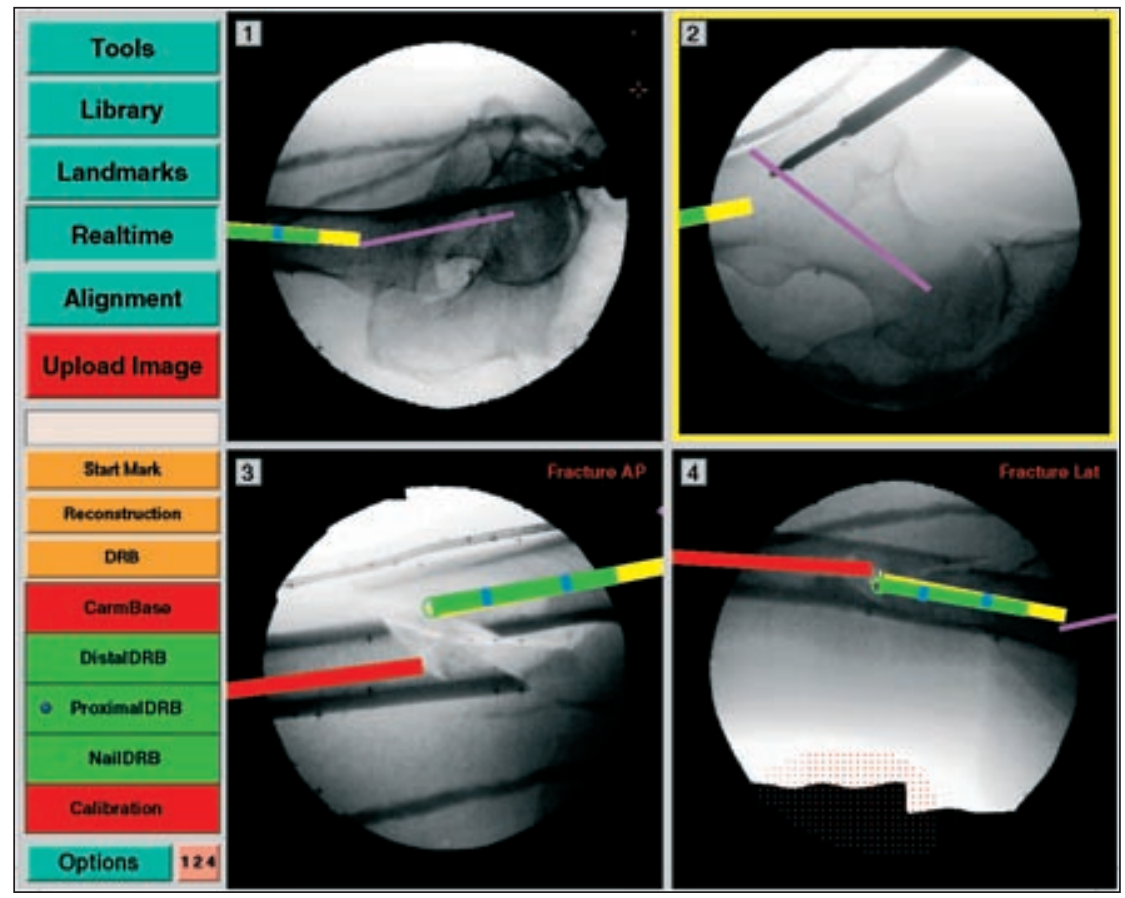

Figure 4

The virtual representation of the nail is advancing in the proximal fragment parallel to the virtual axis. After the two axes are aligned the nail can be inserted in the distal fragment.

\section{Experiments and goals}

To evaluate the anteversion and length values provided by the navigation system a golden standard, based on CT data was developed by the Image Science Institute Utrecht.

For landmarking, a special purpose computer program was developed (www.imagexplorer.nl) that allows navigation through coronal, sagittal and axial planes of CT data. A fourth window showed an additional $3 \mathrm{D}$ reconstruction. In these four windows three investigators defined the same landmarks as in the fluoroscopic images. (see figure 6)

The landmarks defined the anteversion angles and lengths according to their definition by Hofstetter. This made a comparison possible between the anteversion angles and lengths determined by both methods.

Preoperative CT scans of all unfractured legs were acquired and stored in a database. Subsequently, three investigators calculated the femoral length and anteversion for each femur by 3D CT landmark definition. Additionally, the inter-investigator variance was analysed.

Following attachment of both DRF's in the unfractured femur, fluoroscopic images of the proximal and distal femur were obtained in AP and AX direction. The same three investigators 
Validation of computer assisted anteversion and length control in closed nailing of femoral shaft $\mathrm{fr}$

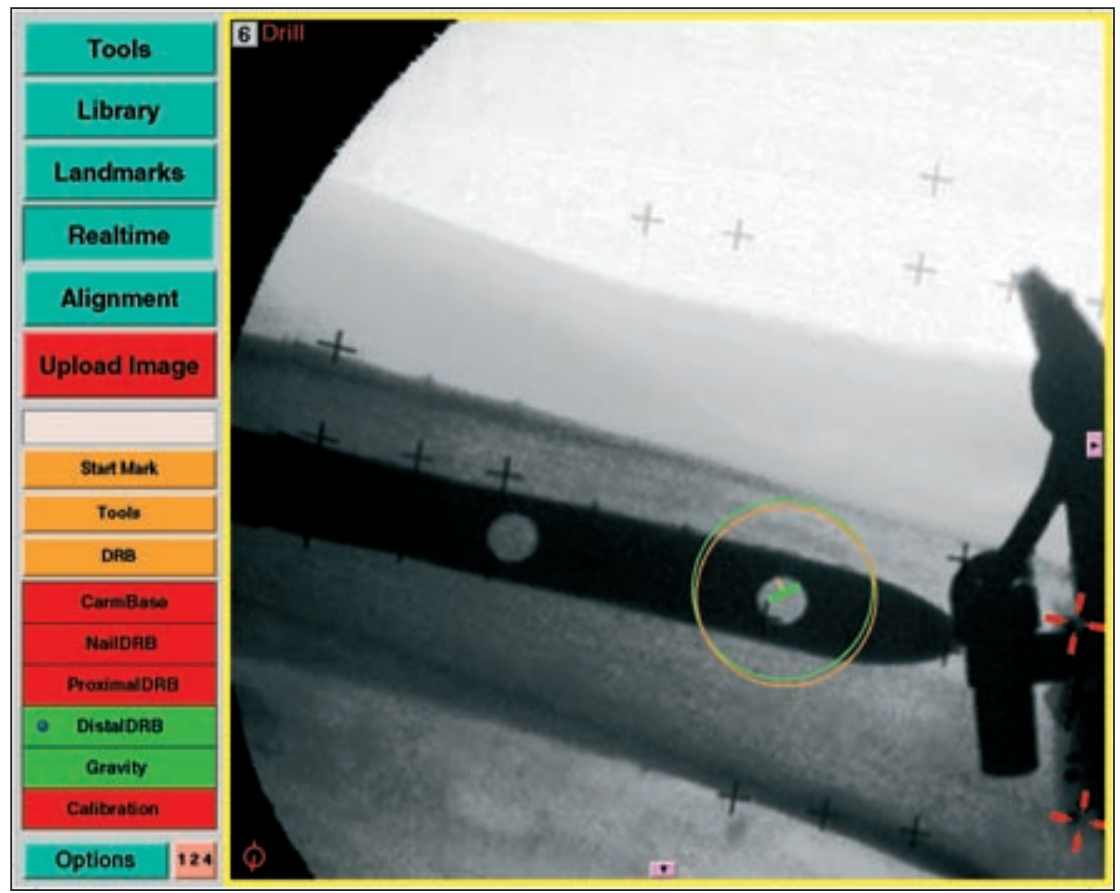

Figure 5

Distal locking was performed by loading an additional AX fluoroscopic image, showing the distal locking holes with a maximum diameter, as a perfect circle. The position of a calibrated $4 \mathrm{~mm}$ drill was projected in this image during the distal locking procedure.

defined the landmarks in these fluoroscopic images. Consequently, three pair of anteversion and length values were obtained for each unfractured femur. These values were compared with the CT-based one's. The inter-investigator variance was calculated for the computerassisted method as well.

Next, midshaft transverse femur fractures were created with an osteotomy. The fractures were deliberately reduced with some rotation mistake to create variety in the postoperative evaluation of rotation measurements. The quality of the CAS distal locking procedure was scored as inadequate or adequate position of the drillbit. In all procedures the nails were locked statically. The anteversion angles and lengths displayed by the navigation system at the end of each procedure were recorded. Finally, CT scans of all stabilised femurs were acquired and the three investigators computed the postoperative anteversion and length using the CT based method. Additionally, these data were compared with the data provided by the navigation system. 


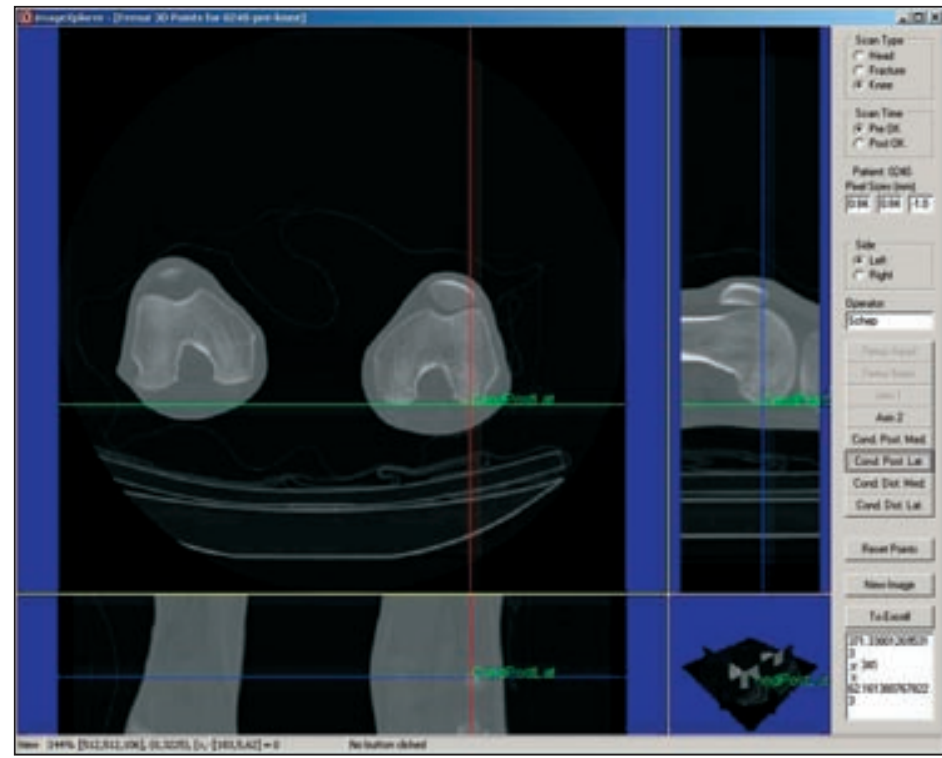

Figure 6

The same landmarks were identified in a coronal, sagittal and axial plane CT image plane. Here the lateral posterior femoral condyle is identified.

\section{Statistical analysis}

The means of the three length and rotation values were calculated for each method in every femur, pre- and postoperatively. Wilcoxon Signed rank tests were used to evaluate differences in length and rotation between the CT based and fluoroscopy based data.

Inter-investigator variance in length and rotation for both methods was evaluated in the pre-operative data. The difference in rotation and length measurement between the three investigators was calculated as the difference between the highest and lowest values. A Wilcoxon Signed rank test was used to test whether there was a difference in interinvestigator variance between the CT- and fluoroscopy based data. $\mathrm{P}<0.05$ was considered a statistically significant difference.

\section{Results}

Table 1 shows the comparison of the CAS based rotation and length values in relation to the CT based values see table 1 .

The mean difference between the investigators using the fluoroscopy-based method was $5.5^{\circ}$ (1-11) for anteversion and $5.2 \mathrm{~mm}(2-10)$ for femoral length. The CT based method showed a mean difference of 3.1 degrees (0.41-7.97) in anteversion and $2.5 \mathrm{~mm}$ (0.78-5.94) in length. A significant difference in inter-investigator variance between both methods was 
found for length $(P=0.04)$. Inter-investigator variance for rotation showed no significant difference $(P=0.14)$.

Computer aided distal locking was successful in nine procedures, in one procedure the drill was positioned dorsally from the locking hole.

\section{TABLE 1}

$\begin{array}{lccc} & \text { Mean difference CT based and CAS method } & \text { S.D. } & \text { p-value } \\ \text { Pre-operative rotation } & 11.7^{\circ} & 6.1 & 0.005 \\ & (3.9-24.8) & & \\ \text { Post-operative rotation } & 15.1^{\circ} & 9.7 & 0.011 \\ & (1.7-26.2) & & \\ \text { Pre-operative length } & 2.8 \mathrm{~mm} & 2.2 & 0.005 \\ & (0.7-7.1) & & \\ \text { Post-operative length } & 5.9 \mathrm{~mm} & 4.3 & 0.005 \\ & (0.4-12.1) & & \end{array}$

\section{Discussion}

The goal of this study was to evaluate the reliability of restoration of anteversion angles and lengths of a fractured femur using a navigation system. The pre- and postoperative length and rotation values obtained with CAS were compared with CT-based data (the gold standard). The differences in length measurement between the CAS and CT based method were less than one centimetre, a difference that is not clinically relevant.

The variation in measured anteversion angles between the CAS and CT based method showed a difference of more than $11^{\circ}$ in the preoperative data and more than $15^{\circ}$ in the postoperative data with a maximum $26^{\circ}$.

The differences between the CT based and CAS method can be explained by difficulties in image acquisition and landmark definition. The anteversion angle is for an important part defined by the femoral neck axis. For adequate identification of this axis it is necessary to obtain pure AP and AX fluoroscopic images of the proximal femur. In clinical practice this may be troublesome due to the patient's position on the operating table. Even when optimal fluoroscopic images are obtained the exact axis through the femoral neck and centre of the femoral head remains difficult to define "manually". The inter- investigator variance for anteversion angles using the CAS method reveals this dilemma with a mean variance of almost $6^{\circ}$ with a maximum of $11^{\circ}$, using one set of fluoroscopic images. Hofstetter found a variance between three investigators with a mean of $3.6^{\circ}$ and a maximum of $9^{\circ}$. The use 
of fresh cadavers and consequently a less fluoroscopic image quality may be responsible for our worse outcome.

Applying the CT-based method the femoral neck axis is defined in three different image planes, which makes identification more straightforward and accurate. This argument supported our theory that the CT-based method is to be accepted as the gold standard. However, a significant difference in inter-investigator anteversion variance between the CT and CAS method could not be determined. This is probably due to the limited number of data. For variance in lengths the difference was significant.

Navigated distal locking was successful in nine out of ten procedures. The inadequate positioning of the drill in one procedure was most probably caused by a non-rigid fixation of the distal DRF.

Up till now this is the only study in which the CAS procedure for the nail insertion is performed in cadavers instead of sawbones. Therefore, we would like to comment on the clinical procedure. In a previous study it was showed that the projection of the drill in the fluoroscopic images is accurate with a mean deviation of $\left.0.9 \mathrm{~mm} .{ }^{6}\right)$ Consequently, in this experiment it was possible to position the drill in the pirifirmis fossa accurately.

Once the calibrated nail was inserted and had reached the fracture region the surgeon had to align the proximal and distal fragment and advance the nail with the help of the navigation system. When the fragments were moved, the axis of the distal fragment was moving out the $X$-ray representation. In practice it appeared to be difficult to target the tip of the nail on the predefined virtual distal axis due to its relative small diameter. To smooth the progress of this procedure it will help the surgeon to see the actual fracture fragments move, instead of the virtual axis.

\section{Conclusions}

the length measurements provided by the navigation system showed to be reproducible and accurate enough for clinical use. The rotation measurements were reproducible with a difference of almost six degrees but not accurate enough to prevent malrotation considering the CT based method as the gold standard. When using the anteversion angle of the contralateral (unbroken) extremity as a template for the reduction the inter investigator variance may be enough to avoid outliers. This will be the subject for further research. 


\section{Reference List}

1. Braten, M., Terjesen, T., and Rossvoll, I.: Torsional deformity after intramedullary nailing of femoral shaft fractures. Measurement of anteversion angles in 110 patients. J. Bone Joint Surg. Br. 75:799803, 1993.

2. Braten, M., Terjesen, T., and Rossvoll, I.: Femoral shaft fractures treated by intramedullary nailing. A follow-up study focusing on problems related to the method. Injury. 26:379-383, 1995.

3. Hofstetter, R., Slomczykowski, M., Krettek, C., Koppen, G., Sati, M., and Nolte, L. P.: Computerassisted fluoroscopy-based reduction of femoral fractures and antetorsion correction. Comput. Aided Surg. 5:311-325, 2000.

4. Madan, S. and Blakeway, C.: Radiation exposure to surgeon and patient in intramedullary nailing of the lower limb. Injury. 33:723, 2002.

5. Mehlman, C. T. and DiPasquale, T. G.: Radiation exposure to the orthopaedic surgical team during fluoroscopy: "how far away is far enough?". J. Orthop Trauma. 11:392-398, 1997.

6. Schep, N. W. L., van Walsum, TH., de Graaf, J. S., Broeders, I. A. M. J., and van der Werken, Chr. Validation of fluoroscopy based navigation in the hip region. HU Lemke et al. CARS 2002. Amsterdam, Elsevier sciences. 26-6-2002. 


\section{Chapter}

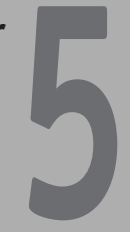

\section{Virtual planning of anterior cruciate ligament insertion.}

\section{"Validation of a new technique"}

N.W.L. Schep1; M.H.J. Stavenuiter2, C.H. Diekerhof2, E.P.Martens3, M.van Haeff2, I.A.M.J.Broeders1, D.B.F. Saris2

1 Department of Surgery, 2 Department of Orthopaedic Surgery

3 Centre for Bio statistics, University Utrecht

University Medical Centre Utrecht, The Netherlands

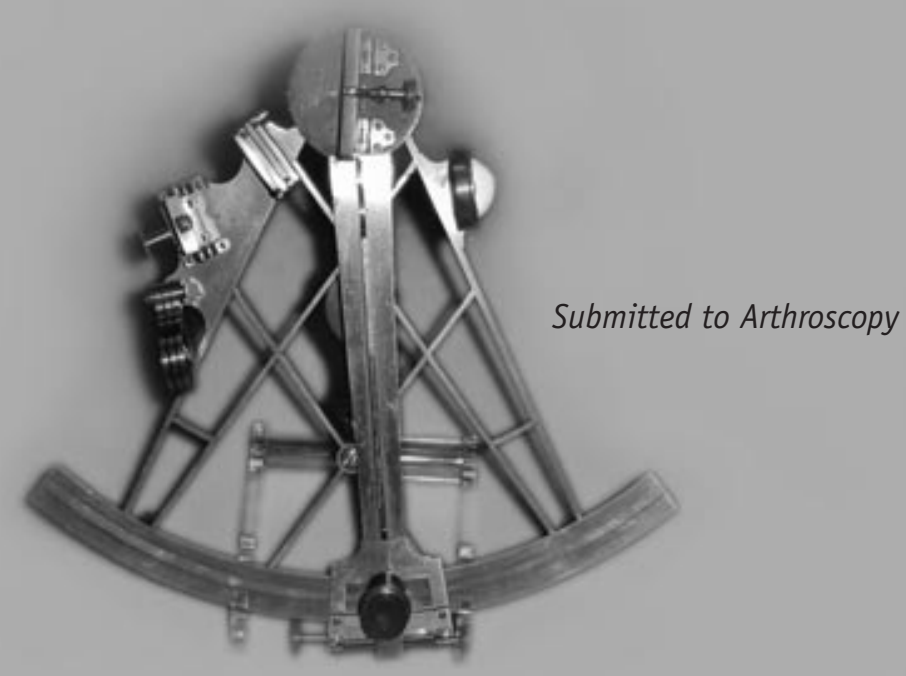




\section{Summary}

Objective: To evaluate surgical variance in positioning an anterior cruciate ligament graft using computer aided technique. Secondary, computer aided planning was compared with a conventional procedure in the same knee.

Materials and Methods: The study was performed in 12 cadaver knees. Three surgeons with a different experience level participated. Computer aided ACL planning was compared between two surgeons in the same cadaver knee. The computer system outlined an impingement area and visualised graft elongation in a virtual manner. Both surgeons positioned the virtual graft in such a way that impingement was avoided and graft elongation was $<4 \mathrm{~mm}$ during flexion and extension. The hypothesis of no difference between both planning procedures was tested. A third surgeon performed a conventional procedure on the same cadaver knee. The position and kinematics of this graft were also analysed with the computer system. Additionally, the hypothesis was tested that the difference between the two planning procedures was dissimilar to the mean difference between the both planning procedures and the conventional procedure.

Results: The difference in planning was $5.02 \mathrm{~mm}$ (Std 2.40, 1.77-9.64) for the tibial and $4.61 \mathrm{~mm}$ (Std 2.13, 2.06-8.42) for the femoral tunnel. The mean difference between the planned and conventional procedures was $6.20 \mathrm{~mm}$ (Std 2.49, 3.00-10.39) in the femur and $6.46 \mathrm{~mm}$ (Std.2.27. 2.65-10.47) in the tibia. No significant differences were observed when the mean distance between the two planning procedures was evaluated in relation to the mean distance between the both planning procedures and the conventional procedure. The two less experienced surgeons were responsible for three impingement cases performing a conventional procedure.

Conclusion: Computer aided planning may reduce inter-surgical variance. Less experienced surgeons and residents can benefit from the system to reduce the number of malpositioned tunnels. 


\section{Introduction}

Endoscopic reconstruction of a torn anterior cruciate ligament $(\mathrm{ACL})$ with a patellar tendon graft is a commonly performed procedure. In the United States more than 50.000 knees are reconstructed each year. $\left.{ }^{6}\right)$ The most critical step in this procedure is placement of the femoral and tibial tunnels, in which the graft is secured. An accurate position of these tunnels can minimise stretching of the graft and decreases the risk of impingement against the roof of the notch during extension of the knee. $\left({ }^{1 ; 4-7}\right)$ The consequences of graft over stretching include graft tightening, graft slackening and graft failure. Whereas, impingement may lead to persistent effusion, failure to regain full extension and eventually graft failure. $\left({ }^{10}\right)$

To improve the accuracy and reproducibility of graft placement, intraoperative virtual reality was added to traditional ACL reconstruction technique. Desenne et al. introduced a computer system to predict notch impingement and graft elongation. $\left.{ }^{3}\right)$ With this technique a virtual knee was reconstructed and displayed on a computer screen. Intra-operatively, the surgeon defined the femoral and tibial attachment sides of the graft. Next, the computer created a virtual ACL between these points. During flexion and extension of the knee the surgeon was able to monitor impingement and elongation of the graft. $\left({ }^{9}\right)$ Theoretically, this way of virtual planning should diminish the variance between surgeons and may lead to a more accurate and reproducible procedure. Sati et al. described an experiment with six surgeons positioning an $\mathrm{ACL}$ in one cadaver knee with this computer aided technique. This study described a tight graphical clustering of the six planned ligament positions, demonstrating a small variance in positioning both tunnels. $\left({ }^{9}\right)$

The aim of our study was to test this hypothesis in a larger study and to illustrate surgical variance in $\mathrm{mm}$. Therefore, the virtual planning for insertion points in the tibia and femur was compared between surgeons. Secondary, the computer aided virtual planning was compared with the insertion points of a conventional procedure in the same knee.

\section{Materials and Methods}

The study was performed in 12 fresh cadaver knees. After introduction of the endoscope (Arthrex, Napels, Florida, USA) the ACL and its footprint were removed with a shaver (Dyonics PS3500EP, Smith \& Nephew Inc, Andover, Ma). Position tracking of the femur, tibia and palpation hook was performed by an opto-electric navigation system. Therefore, both long bones and the palpation hook were equipped with a rigid shield holding light emitting diodes (LED's). The LED's on femur and tibia were called the dynamic reference 
frames (DRF's). An opto-electric camera (Optotrak 3020, Nothern Digital, Waterloo, Canada), overlooking the surgical field, received the signals emitted by the LED's. (Figure 1) This allowed the workstation (Medivision, Oberdorf, Switzerland) to calculate the relative motion between the femur, tibia and palpation hook.

At the start of each procedure the point of the palpation hook was calibrated to define the coordinates of its tip and axis in relation to its LED shield. Next, a set of landmarks was collected with this palpation hook. Therefore, the surgeon placed the tip of the palpation hook on a certain anatomical point and pressed a footswitch. The anterior side of the notch was defined by digitising a collection of surface points under endoscopic control. These points defined the area of impingement with the planned ACL graft. Finally, the preferred attachment points of the ACL in femur and tibia were digitised which enabled the system to draw a virtual knee with its proposed ligament reconstruction.

Impingement was visualised by the graphical intersection of the virtually planned ligament with the digitised anterior notch surface during extension of the knee. In another window the elongation of the graft in $\mathrm{mm}$ was shown during a range of motion of $90^{\circ}$ flexion and complete extension.(Figure 2)

Three surgeons participated in the project. Surgeon A had performed more than $300 \mathrm{ACL}$ reconstruction procedures. Surgeon $B$ just finished his residency and had experience in twenty cases and surgeon $C$ had no surgical experiences in this area.

First, the virtual planning of the tibial and femoral ACL insertion was compared between two surgeons in the same cadaver knee. Both surgeons were blinded for each other's planning. Each surgeon performed eight planning and four conventional procedures in the 12 different knees. During computer aided planning the goal was to define the position of the tibial and femoral tunnel in such a way that impingement with the anterior notch was avoided during extension. Graft elongation had to be less than four mm during the whole range of motion. The diameter of the simulated graft was set to eight $\mathrm{mm}$ in all cases.

The position of both tunnels was defined by the centre of the cylinder representing the virtual $\mathrm{ACL}$ and was provided by the computer system in XYZ coordinates. The femoral tunnel coordinates were calculated using the femoral DRF as a reference, whereas the tibial tunnel coordinates referred to the tibial DRF. The variance in planning between two surgeons was calculated by subtraction of XYZ coordinates to determine point to point discrepancy in $3 \mathrm{D}$ orientation. This distance represented the variance between surgeons in planning the femoral and tibial tunnels. Additionally, the relationship between the difference in planning and the experience level of the surgeons was evaluated. 
Virtual planning of anterior cruciate ligament insertion

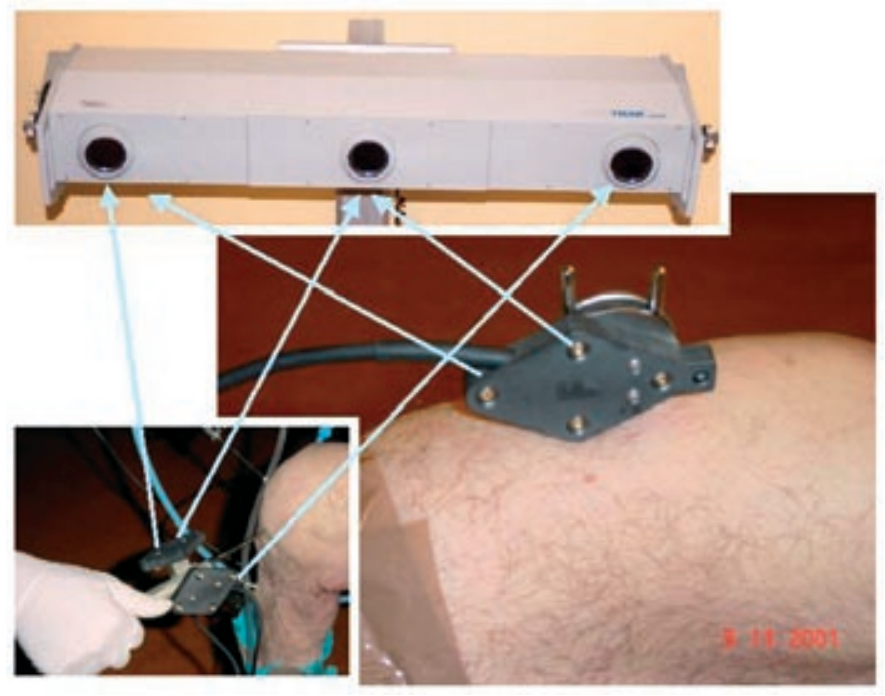

Figure 1

Shields with Light Emitting Diodes (LED's) were attached to the tibia, femur and palpation hook for position tracking. The opto-electric camera received these signals and sent them to the workstation

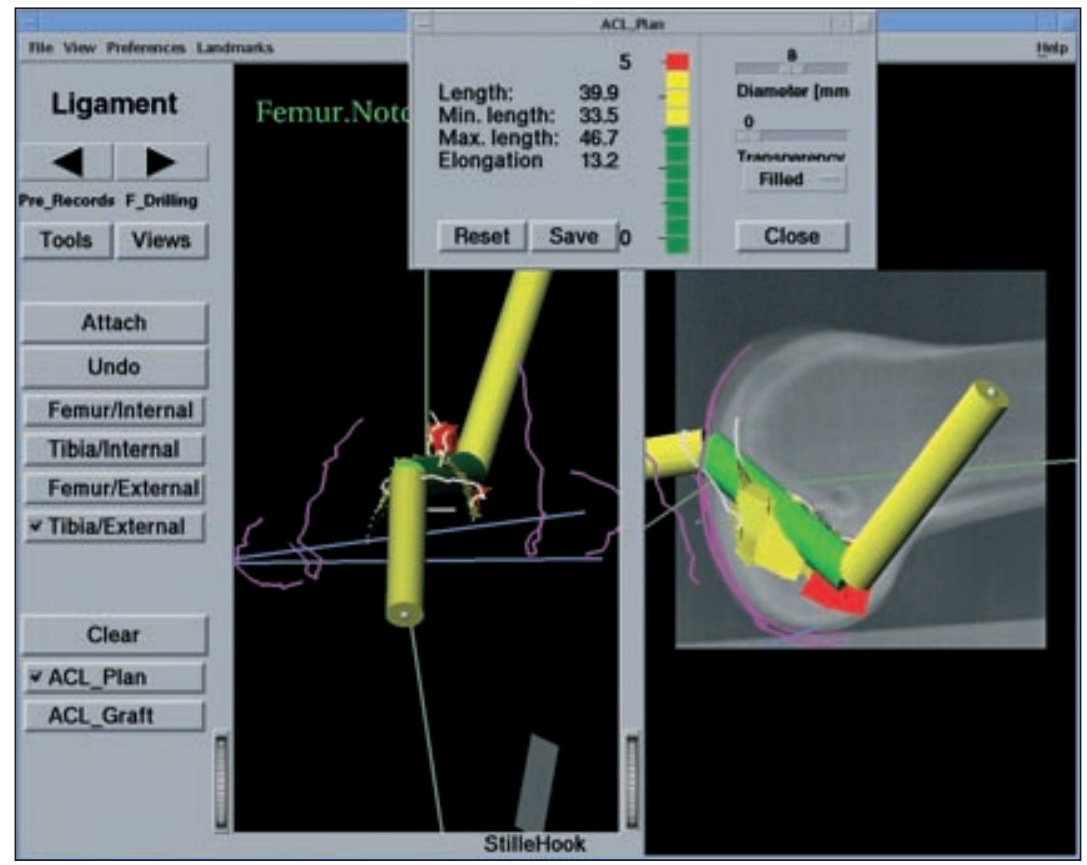

\section{Figure 2}

Impingement was visualised by the graphical intersection of the virtually planned ligament with the digitised anterior notch surface during extension of the knee. In another window the elongation of the graft in $\mathrm{mm}$ was shown during a range of motion of $90^{\circ}$ flexion and complete extension 
A third surgeon performed a conventional procedure on the same cadaver knee. All surgeons performed a total of four conventional procedures. A tibial aiming device (Arthrex, Napels, Florida, USA) was used to drill the tibial tunnel with a guide wire. Drilling was stopped just when the cortex of the tibia plateau was penetrated. The tip of the guide wire resembled the centre of the tibial tunnel and was digitised to obtain its coordinates. Next, a five mm over the top femoral aiming guide (Arthrex, Napels, Florida, USA) was used to drill the femoral guide wire. The point at which the guide wire entered the femoral cortex was subsequently digitised and its coordinates were stored. During the complete procedure an arthroscopy pump (Duo+, Future Medical Systems, Nice, France) was used to remove debris.

Once more a virtual $\mathrm{ACL}$ with an eight millimetre diameter was drawn by the workstation, representing positioning of the $\mathrm{ACL}$ graft using the conventional technique. The incidence of notch impingement and the elongation were scored during flexion and extension of the knee. Finally, the difference in tunnel position between the two virtual planning procedures and the conventional procedure was calculated.

\section{Statistics}

First, the mean difference in $\mathrm{mm}$ between both virtual planning procedures for the femoral and tibial tunnels was calculated. The hypothesis of no difference in distance between both planning procedures was tested with a paired T-test. A Kruskal-Wallis test was used to analyse if the differences in planning were related to the experience level of the surgeons. Next, the mean difference in tunnel position between the conventional procedure and the both planned procedures was calculated. Figure 3 Additionally, the hypothesis was tested that the difference between the two planning procedures ( $\Delta$ plan) was dissimilar to the mean difference between the both planning procedures and the conventional procedure ( $(\Delta$ plan 1-Co $+\Delta$ plan 2-Co) $/ 2$ ). A paired sample T-test was used to test this hypothesis for the femoral and tibial insertion points.

In a total of 12 conventional procedures the median elongation and impingement ratio was scored. An oneway Anova was used to evaluate the relationship between the experience level of the surgeon, performing the conventional procedure and the difference between planning and the conventional procedure. 


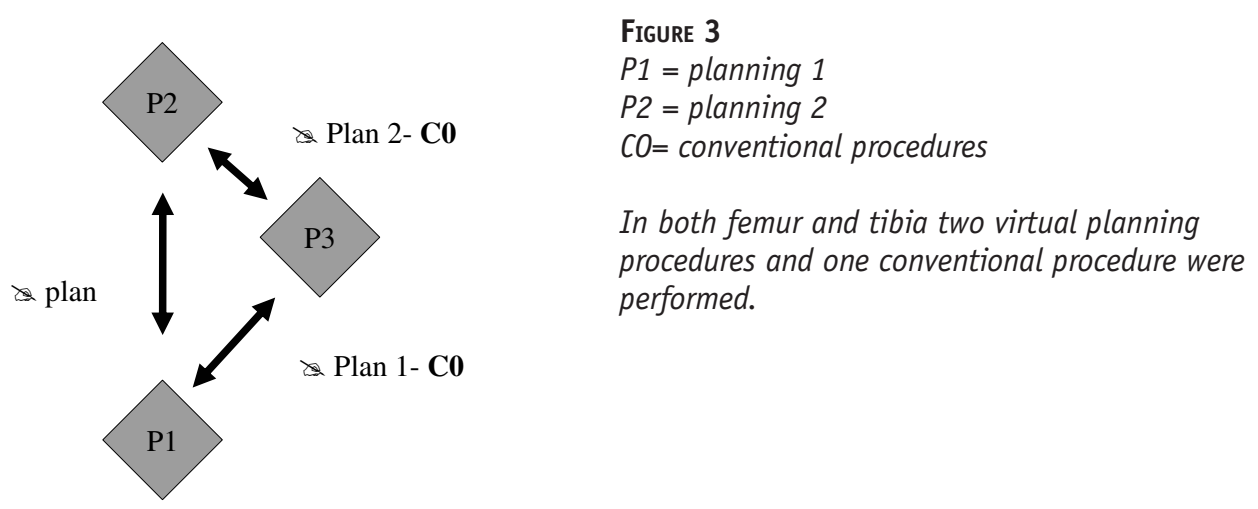

\section{Results}

The positioning of the virtual tibial tunnels showed a mean difference in planning of 5.02 $\mathrm{mm}$ (Std 2.40, 1.77-9.64). The mean difference between the virtual planning for the femoral tunnels was $4.61 \mathrm{~mm}$ (Std 2.13, 2.06-8.42). The difference in distance between the tibial and femoral planning was not significant with $p=0.75$. Additionally, the experience level did not influence the difference in virtual planning between the three surgeons with $p=0.08$ for the femoral and $p=0.52$ for the tibial tunnel.

The mean difference between the planned and conventional procedures in the femur was $6.20 \mathrm{~mm}$ (Std 2.49, 3.00-10.39). In the tibia a mean difference of $6.46 \mathrm{~mm}$ (Std.2.27. 2.6510.47 ) was found. No significant differences were observed when the mean distance between the two planning procedures was evaluated in relation to the mean distance between the both planning procedures and the conventional procedure. Table 1

TABLE 1

\begin{tabular}{lccc}
\hline Paired Sample T-test & Mean & Std. Deviation & Sig. \\
Pair 1 $\Delta$ plan 1-Co $+\Delta$ plan 2-Co (Femur) & 6.20 & 2.49 & 0.33 \\
$\Delta$ plan (Femur) & 4.61 & 2.13 & \\
Pair 2 $\Delta$ plan 1-Co $+\Delta$ plan 2-Co (Tibia) & 6.46 & 2.27 & 0.85 \\
$\Delta$ plan (Tibia) & 5.02 & 2.40 &
\end{tabular}

No significant differences were observed when the mean distance between the two planning procedures was evaluated in relation to the mean distance between the both planning procedures and the conventional procedure. 
The 12 virtual ACL's, drawn after digitising the conventionally defined femoral and tibial insertion points, showed impingement in three cases. Surgeon B performed one of these operations and surgeon $C$ was responsible for two of these cases. One of the impinging knees and two others demonstrated an elongation of more than four mm (median $3.15 \mathrm{~mm} \mathrm{Std}$ $1.84,1.10-7.50)$. All three the surgeons were responsible for one. No relationship between the experience level of the surgeon, performing the conventional procedure and the distance between planning and the conventional procedure could be demonstrated. Table 2

TABLE 2

$\begin{array}{lcccc}\text { Oneway Anova } & \text { Surgeon } & \text { Mean } & \text { Std. Deviation } & \text { Sig. } \\ \Delta \text { plan 1-Co + } \Delta \text { plan 2-Co (Femur) } & \text { A } & 5.60 & 3.04 & 0.67 \\ & \text { B } & 5.84 & 2.07 & \\ \text { pplan 1-Co + } \Delta \text { plan 2-Co (Tibia) } & \text { C } & 7.39 & 2.61 & \\ & \text { A } & 8.44 & 2.09 & 0.06 \\ & \text { B } & 5.91 & 1.20 & \\ & \text { C } & 4.90 & 1.72 & \end{array}$

No relationship between the experience level of the surgeon, performing the conventional procedure and the mean distance between the both planning procedures and the conventional procedure could be demonstrated.

\section{Discussion}

The initial aim of this study was to evaluate the inter-surgical variance in computer aided planning of a virtual ACL graft. The difference between the two planning procedures proved to be approximately five $\mathrm{mm}$ in both tibia and femur. Furthermore, this study showed that the experience level of the surgeon had no effect on the position of these virtual tunnels.

The difference in planning may indicate that there are several appropriate locations for $\mathrm{ACL}$ insertion, which avoid impingement and include an elongation of less than $4 \mathrm{~mm}$ as well. This is in accordance with the study of Zavras et al. This study confirmed the existence of an isometric zone close to the Blumensaat's line. $\left({ }^{10}\right)$

In this study no bone patella bone graft was inserted. This was due to the fact that two planning procedures and one conventional procedure had to be performed in the same 
cadaver knee. Consequently, no validation of graft kinematics could be executed. Therefore, the values of the computer were defined as the standard in all tests.

Secondary, computer aided virtual planning was compared with the tunnel position of a conventional procedure. The mean distance between the planned and the conventional procedures proved to be more than six $\mathrm{mm}$ for both the tibia as the femoral tunnel. No significant difference with the distance between the two planned procedures could be observed. However, there is a trend showing that the positions of both planning procedures are more close related. The mean of $\Delta \mathrm{P}$ shows to be smaller compared with the mean distance to conventional positioning in both femur and tibia, which resembles a decrease in the margin of error.

The virtual graft, drawn after the conventional procedure, showed impingement in three out of twelve knees and an elongation of more than four $\mathrm{mm}$ in two additional knees. The less experienced surgeon was responsible for two of these impingement cases. The three knees with an elongation of more than four $\mathrm{mm}$ were equally distributed among the three surgeons. These data connect with the hypothesis that less experienced surgeons will have a higher impingement rate compared with experienced surgeons.

The meaning of intra-operative isometry measurement is still controversial. Some authors recommend an isometric area for $\mathrm{ACL}$ placement others claim that isometry has little effect on the clinical outcome. $\left({ }^{2 ; 6 ; 10}\right)$ The European Society of Sports traumatology Knee surgery and Arthroscopy recommended in their second workshop "a good choice of graft attachment points will result in minimal changes in their separation distance as the knee flexes and extends". $\left({ }^{1}\right)$ It is important to realise that even if a perfect isometric point could be located and the bone tunnels are positioned around this point a reconstruction with a bone patella bone graft is not isometric due to the acentric insertion of the graft on the bone blocks. Tendon grafts, however, do have a central placement within the tunnels. This may help to improve clinical outcome based on isometric parameters.

No significant relationship between the experience level of the surgeon, performing the conventional procedure and the distance to the planning was observed. However, the most experienced surgeon proved to locate the femoral tunnel the nearest to the planned position. Surprisingly, this same surgeon positioned the tibial tunnel with the largest discrepancy compared to the plan. However, in all these cases no impingement was observed and in one case elongation was $>4 \mathrm{~mm}(7.5 \mathrm{~mm})$. Literature shows that the femoral attachment side has a greater effect on graft length changes than does the tibial attachment. $\left({ }^{1}\right)$ This may be an explanation for the discrepancy in the relation between experience and tibial position. 
In conclusion this study indicates that computer aided planning may reduce the intersurgical variance. Moreover, the experience level of the surgeon did not effect the planning process. Secondary, less experienced surgeons and residents can benefit from the system to reduce the number of malpositioned tunnels. The literature teaches us that the incidence of misplaced tunnels may be as high as $40 \%$. $\left(^{8}\right)$ Randomised trials must be performed in the future to judge whether the computer-aided technique may lower this figure and offers the patients a better clinical outcome. $\left({ }^{9}\right)$ 


\section{Reference List}

1. Amis, A. A. and Jakob, R. P.: Anterior cruciate ligament graft positioning, tensioning and twisting. Knee. Surg. Sports Traumatol. Arthrosc. 6 Suppl 1:S2-12, 1998.

2. Barrett, G. R. and Treacy, S. H.: The effect of intraoperative isometric measurement on the outcome of anterior cruciate ligament reconstruction: a clinical analysis. Arthroscopy. 12:645-651, 1996.

3. Dessenne, V., Lavallee, S., Julliard, R., Orti, R., Martelli, S., and Cinquin, P.: Computer-assisted knee anterior cruciate ligament reconstruction: first clinical tests. J. Image Guid. Surg. 1:59-64, 1995.

4. Fineberg, M. S., Zarins, B., and Sherman, 0. H.: Practical considerations in anterior cruciate ligament replacement surgery. Arthroscopy. 16:715-724, 2000.

5. Fineberg, M. S., Zarins, B., and Sherman, 0. H.: Practical considerations in anterior cruciate ligament replacement surgery. Arthroscopy. 16:715-724, 2000.

6. Frank, C. B. and Jackson, D. W.: The science of reconstruction of the anterior cruciate ligament. J. Bone Joint Surg. Am. 79:1556-1576, 1997.

7. Frank, C. B. and Jackson, D. W.: The science of reconstruction of the anterior cruciate ligament. J. Bone Joint Surg. Am. 79:1556-1576, 1997.

8. Picard, F., DiGioia, A. M., Moody, J., Martinek, V., Fu, F. H., Rytel, M., Nikou, C., LaBarca, R. S., and Jaramaz, B.: Accuracy in tunnel placement for ACL reconstruction. Comparison of traditional arthroscopic and computer-assisted navigation techniques. Comput. Aided Surg. 6:279-289, 2001.

9. sati, M., Staubli, H. U., Bourquin, Y., Kunz, M., and Nolte, L. P.: Real-time computerized in situ guidance system for acl graft placement. Comput. Aided Surg. 7:25-40, 2002.

10. Zavras, T. D., Race, A., Bull, A. M., and Amis, A. A.: A comparative study of 'isometric' points for anterior cruciate ligament graft attachment. Knee. Surg. Sports Traumatol. Arthrosc. 9:28-33, 2001. 
Chapter

\section{Internal fixation of femoral neck fractures}

\section{with computer assisted surgery.}

\section{"A report on first cases"}

N.W.L. Schep, E.J.M. Verleisdonk, I.A.M.J. Broeders, F.M. Kappelhoff and Chr. van der Werken.

Department of Surgery

University Medical Centre Utrecht, The Netherlands

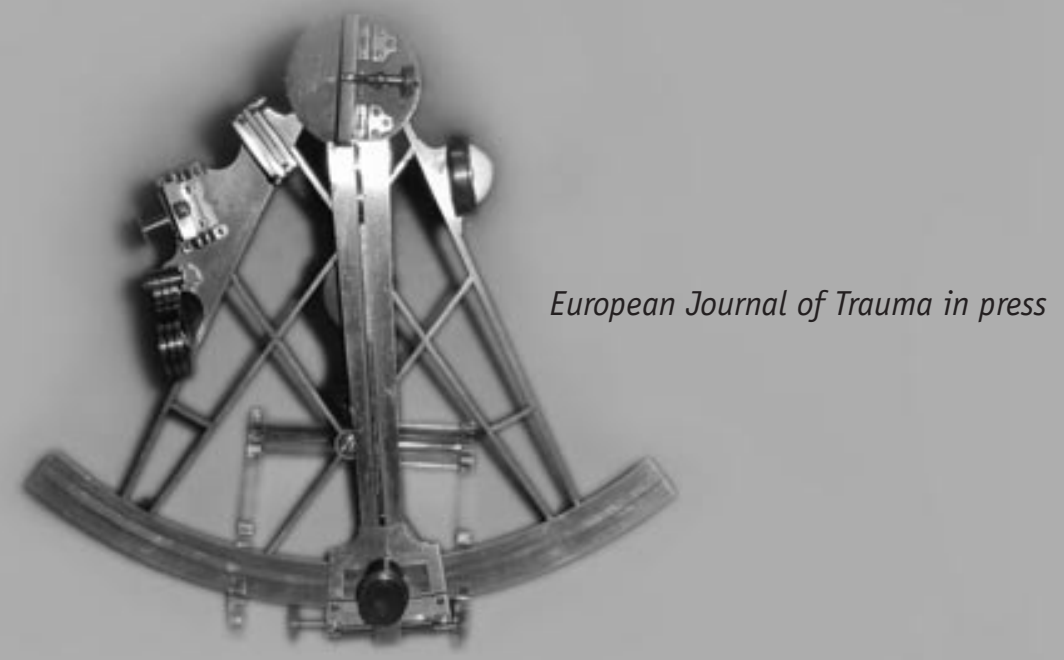




\section{Summary}

Objective: In standard practice, osteosynthesis of femoral fractures is guided interactively by $2 \mathrm{D}$ fluoroscopy providing anteroposterior (AP) or axial (AX) projections. This approach leads to repetitive position changes of the $\mathrm{C}$-arm with concomitant radiation exposure and may result in sub-optimal positioning of implants. Fluoroscopy based navigation may offer a solution for these problems. The goal of this study was to evaluate the feasibility of fluoroscopy based navigation in the treatment of intracapsular femoral neck fractures with a dynamic hip screw (DHS).

Patients and Methods: Seven patients were treated with a $135^{\circ}$ DHS. Fluoroscopy based navigation technique (Medivision, Oberdorf, Switzerland) was used for positioning the correct drill channel for the DHS. Therefore, the virtual position of an 8-mm non-cannulated DHS reamer was superimposed simultaneously on the AP and AX images.

Results: One procedure failed because the position of the virtual drill did not match the true situation. In this case it was most likely that the DRF was moved relative to the proximal femur during the operation. This operation was continued under fluoroscopic guidance. In one patient the DHS was located in the cortex of the femoral head. In another patient the DHS was positioned not exactly in the centre of the femoral neck but slightly posterior. Mean system set-up time was $10 \mathrm{~min}$.

Conclusion: Fluoroscopy based navigation is a feasible technique for the treatment of femoral neck fractures with a DHS. The initial results are encouraging. More intuitive techniques are currently developed to enhance implication of navigation in routine trauma care. 


\section{Introduction}

The dynamic hip screw (DHS, A0-Synthes ${ }^{\circledR}$ ) is a popular implant for the stabilisation of femoral neck fractures. An essential part of the operation is the insertion of a guide wire over the calcar into the femoral head under fluoroscopic guidance.

Drawback of this technique is the intraoperative visualisation, because positional information of the K-wire is limited to single two-dimensional (2-D) fluoroscopic projections. This leads to repetitive position changes of the $\mathrm{C}$-arm because both anteroposterior (AP) and axial (AX) images are required and makes the procedure prone to imperfect positioning of the implant. Moreover, interactive fluoroscopic guidance results in a substantial radiation exposure to both patients and surgical team. $\left({ }^{3 ; 4}\right)$

Fluoroscopy based navigation may offer a solution to these problems. With this technique the virtual position and direction of a drillbit is simultaneously superimposed on standard AP and $\mathrm{AX}$ fluoroscopic images. $\left({ }^{1 ; 2 ; 6}\right)$ Consequently, the channel for the hip screw can be drilled under constant virtual guidance, without the use of a K-wire.

Potential advantages of computer assisted surgery (CAS) in femoral neck fractures are a more accurate and reproducible approach for inserting a DHS-screw and a reduction of fluoroscopy time. These advantages may possibly result in a better patient's outcome and reduction of operation time. In order to test the feasibility and accuracy of drilling and measuring the screw channel of a DHS an experimental study in 20 sawbones was performed. $\left({ }^{5}\right)$ The results of this study were encouraging and led to clinical implementation of this technique.

Consequently, the aim of this clinical study was to evaluate the feasibility and pitfalls of CAS in the treatment of femoral neck fractures with a DHS.

\section{Patients and Methods}

In the operating theatre a tracking sensor was installed (opto-electric camera, Optotrak $3020^{\circledR}$, Northern Digital-inc, Waterloo, Canada) This tracking sensor received signals emitted by infrared emitting diodes (LED's). These LED's were attached to the drill and to the patient. The LED's attached to the patient are called the dynamic reference frame (DRF). (Figure 1) Likewise, the C-arm (Philips BV 300, Best, The Netherlands) was equipped with a shield holding 24 LED's. This allowed position tracking of the C-arm in a wide range of motions relative to the opto-electric camera. C-arm images were calibrated to compensate for the elastic deformation caused by the weight of the components of the $\mathrm{C}$-arm under gravity and for the fluoroscope's image intensifier distortions. $\left({ }^{2}\right)$ 
All patients were operated in supine position on a fracture table. After closed reduction of the fracture the injured leg was brought in traction. In four patients the DRF was attached rigidly with a Steinmann pin in the iliac crest and in three patients in the greater trochanter. Subsequently, AP and AX fluoroscopic images were obtained and loaded into the workstation (Medivision Surgigate ${ }^{\circledR}$, Oberdorf, Switzerland). The AX plane was defined as the projection where the neck axis was exactly in line with the axis of the shaft. Next, the C-arm was rotated exactly $90^{\circ}$. This projection defined the AP plane.

The proximal femur was exposed by means of a $4 \mathrm{~cm}$ straight lateral incision on the thigh. A temporary fixation of the reduced fragments was obtained with a K-wire proximal of the implant site of the hip screw. After merging the positional information of the patient, drillbit and $\mathrm{C}$-arm, the virtual position and direction of the drillbit was superimposed on the AP and AX fluoroscopic images and displayed on the workstation. (Figure 2)

The surgeon instantaneously drilled the hole for the hip screw under constant virtual guidance. The virtual drill was targeted straight over the calcar in AP projection and in the center of the femoral neck in AX projection. Defining the depth of the drill channel was based on the surgeon's judgement on bone quality.

Two adjustments were made to standard instruments. First, a procedure dedicated aiming device was designed, based on the standard $135^{\circ}$ aiming device, with

an $8 \mathrm{~mm}$ channel for the DHS drill.( Figure 3) This enabled the surgeon to drill the channel for the DHS directly in the correct position. Secondly, the standard cannulated $8 \mathrm{~mm}$ DHS reamer was made non-cannulated by fixating a $\mathrm{K}$-wire in the central hole, which exceeded the tip of the drillbit by two $\mathrm{mm}$. The tip of this K-wire was pressed in the lateral femoral cortex just before drilling, establishing better grip on the lateral femoral cortex.

During drilling the starting point at the lateral femoral cortex and the end point at the preferred position just below the joint space were marked by pressing a footswitch. The drill channel depth was computed by the system and displayed on the monitor. Subsequently, the plate reamer was attached to the $8 \mathrm{~mm}$ DHS reamer at the appropriate depth and the plate hole was drilled. Next, the hip screw, a $135^{\circ}$ plate and one $4.5 \mathrm{~mm}$ cortical screw were inserted by standard technique. (Figure 4) 


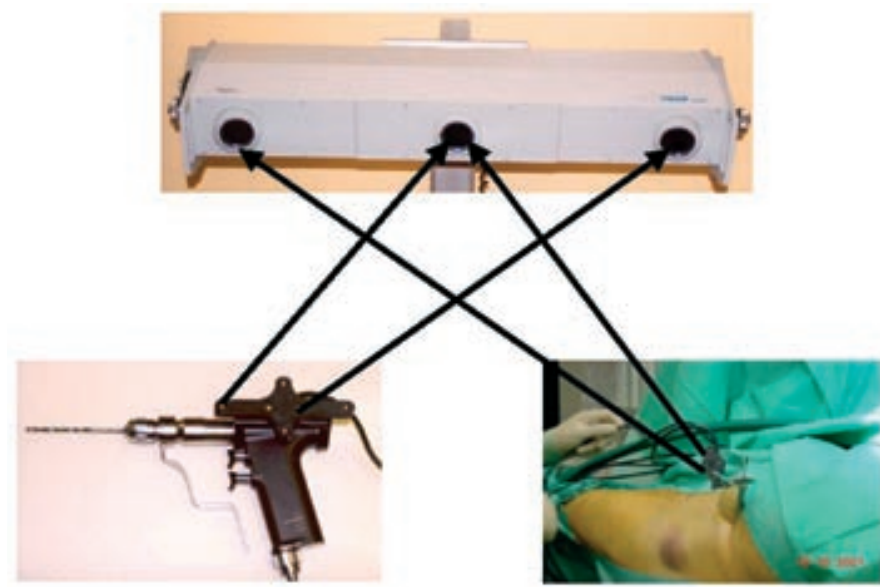

\section{Figure 1}

The opto-electric camera

(Optotrak $3020^{\circledR}$, Northern Digital-inc.) overlooking the surgical field, received signals emitted by infrared emitting diodes (LED's). These LED's were attached to the drill and to the patient, the latter being called the dynamic reference frame (DRF)

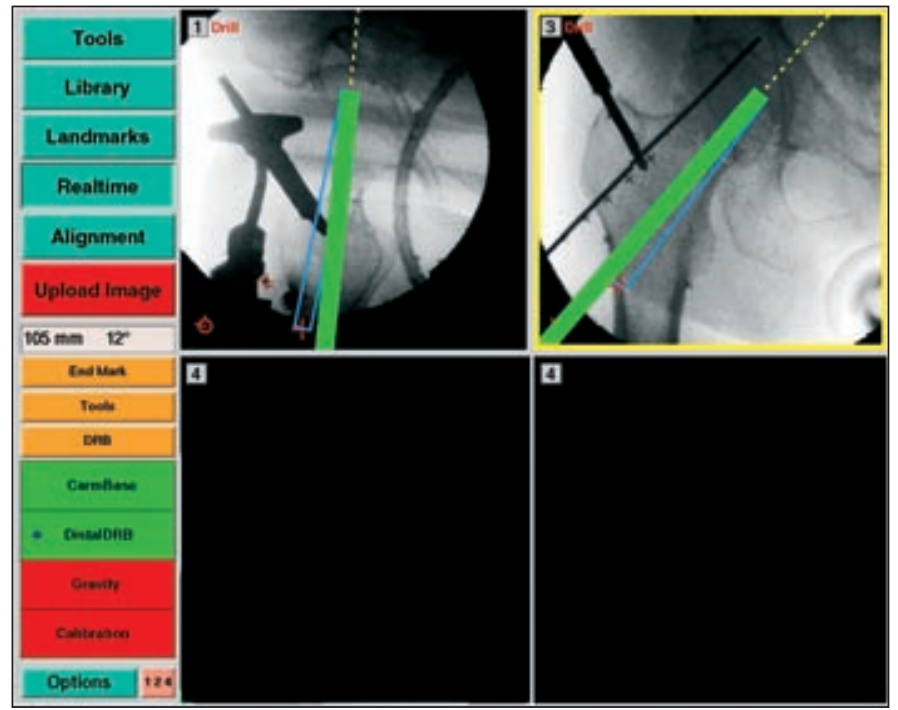

FIGURE 2

The virtual position of the $8 \mathrm{~mm}$ $D H S$ reamer is superimposed on the $A P$ and $A X$ images. Additionally the drill channel depth is also computed by the system and displayed on the monitor.

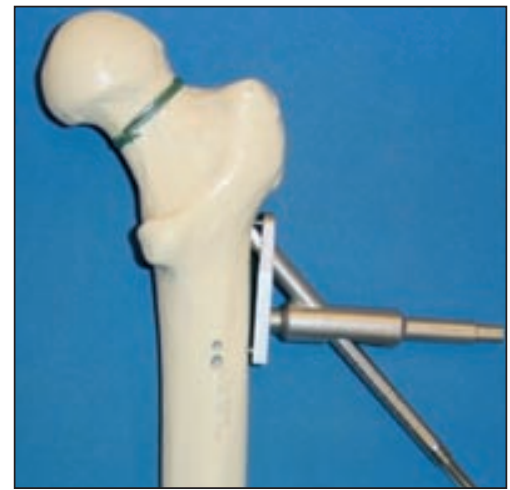

FIGURE 3

$135^{\circ} 8 \mathrm{~mm}$ aiming device with inserted non-cannulated drill 


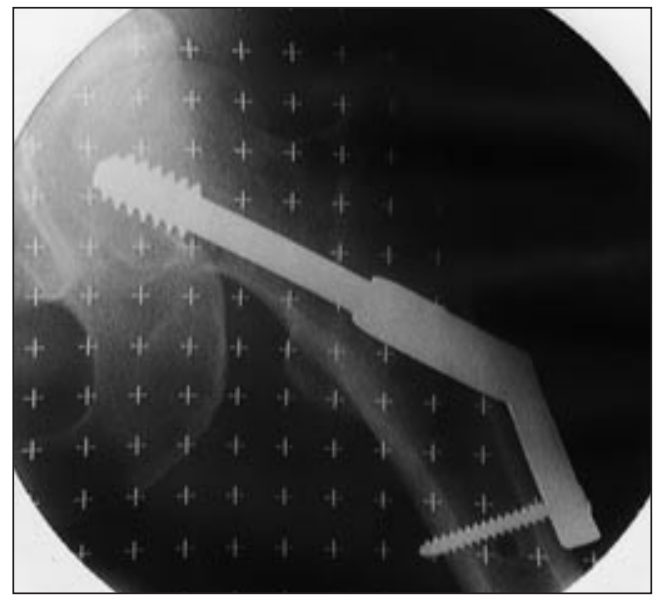

Figure 4

One hole $135^{\circ}$ Dynamic hip screw in situ.

Preoperatively, basic demographic data, including Garden fracture classification were recorded. Intraoperatively, procedure time, operating time and radiation exposure were scored. The $\mathrm{C}$-arm provided the total radiation dose and fluoroscopy time after each procedure. These values were considered representative for the radiation exposure. Postoperatively, the position of the DHS was evaluated on control X-rays.

\section{Results}

Seven consecutive patients ( 6 females, one male) with a femoral neck fracture underwent osteosynthesis with a DHS. Their ages ranged from 53 to 85 years (median, 76 years). Fracture classification according to Garden showed two grade one, one grade two, two grade three, and two grade four fractures.

The median operation time, measured from skin incision to closure, was 44 minutes (range 30-75). The median procedure time, including system set-up time, closed reduction, uploading images in the workstation and extubation of the patient was 120 minutes (range 110-145). For comparison the median procedure time in a series of 42 patients treated with a DHS in our hospital was retrospectively subtracted from patients files. The median procedure time in this conventionally treated group was 108 minutes (range 60-210). An experienced MD performed the set-up of the system in all cases with a median of 10 minutes (range 815). Fluoroscopy time showed a median of 130 seconds (range 85-349) and a median dose of $2.6 \mathrm{~Gy} / \mathrm{cm}^{2}$ (range $2.28-4.39$ )

Six procedures were completed with use of the navigation system. One CAS procedure failed because the position and direction of the virtual drill undoubtedly did not correspond with 
the true anatomic position of the drillbit. This operation was continued conventionally under fluoroscopic guidance.

The postoperative X-rays of the CAS operated patients showed an optimal position of the implant in four cases. In one patient the screw tip was located to far subchondral in the cortex of the femoral head without clinical consequences so far in a six moths follow up. In another patient the DHS was positioned not exactly in the center of the femoral neck but slightly posterior. Postoperatively, one patient developed pneumonia during hospital stay, which was successfully treated with antibiotics.

\section{Discussion.}

The aim of this study was to evaluate the feasibility and to understand the pitfalls of fluoroscopy based navigation in the treatment of femoral neck fractures with a DHS in clinical practice.

In one case the navigation procedure was brought to an end because the position of the virtual drill clearly did not corresponded with the true position. This interrupts the relationship between the proximal femur and the uploaded fluoroscopic images resulting in unreliable virtual feedback of the navigation system.

Intraoperative movement of the DRF or fracture parts is an important pitfall in surgical navigation. It is mandatory to check the accuracy of the system before and during procedures. This can be accomplished by placing the point of the drill on an anatomic or artificial point, which can easily be identified. In that way the surgeon performs a visual control.

In the first four patients we tested the hypothesis that traction of the affected limb could establish a rigid relation between the pelvis and proximal femur. Therefore, the DRF was attached in the iliac crest. This made it simple to obtain a straight line of sight between the opto-electric camera and the LED's of the DRF during image acquisition and drilling. However, non-correspondence between the virtual drill and the clinical situation in the patient, described above, made it clear that during manipulation this fixed relationship could not be guaranteed in all situations. This example emphasizes once more that it is obligatory to fixate the patient's DRF in the operated bone! In the next patients the DRF was fixed in the greater trochanter to rule out movement of the proximal femur relative to the pelvis.

For the same reason, a temporary fixation between both fracture parts was accomplished by a K-wire. (Figure 2) Nevertheless, a rotational instability, as in conventional treatment, 
may still occur. For this reason postoperative fluoroscopic control images were obtained in every patient.

In one patient, with a suboptimal result, the tip of the hip screw was positioned to deeply in the femoral head. In retrospect, it was not possible to clearly identify the contours of the femoral head on the uploaded fluoroscopic images. The quality of the images displayed on the workstation was affected in a negative way by a grid with crossmarks, which is fixated in front of the image intensifier. The system uses these crossmarks to correct image distortions. $\left({ }^{2}\right)$ Especially in patients with poor bone quality and/or adipositas it was difficult to obtain good quality images. Recently, the quality of uploaded images was improved by software adjustments. In the near future more radiolucent grids should be available to solve this problem.

In another case the DHS was positioned slightly posteriorly in the head fragment. However, in retrospect the virtual drill was targeted to posterior as well, which was evident on the intraoperative screenshots of the navigation system.

In the CAS group we found a median procedure time of 120 minutes. In spite the small patient group of only seven patients we want to make a remark about the time loss compared with conventional surgery. The set-up of the system was performed during assigning anesthetics and therefore, can not be held responsible for this time loss. The loss of time can be explained by difficulties in positioning the C-arm and the patient's DRF in sight of the opto-electric camera during image acquisition and drilling. Moreover, in this set up the surgeon had to drill instantaneously through an $8 \mathrm{~mm}$ aiming device. In clinical practice it seemed to be complex to hold the aiming device and the drilling machine while at the same time maintaining enough pressure on the lateral femoral cortex. Repeatedly, the drill slid from the lateral femoral cortex. The absence of a K-wire can be held responsible for this dilemma.

Our limited experience showed that fluoroscopy based navigation in the treatment of femoral neck fractures with a DHS is feasible. The authors wanted to evaluate fluoroscopy based navigation in a routine procedure to gain experience with this new technique. Subsequently, this technique will be applied in more complicated operations e.g. insertion of iliosacral screws and insertion/distal locking of intramedullary nails. The potential of this technique is the possibility to target a drill virtually, which should lead to optimal positioning of implants. CAS can also play an important role in the education of residents and less experienced surgeons in the near future because of this virtual targeting. Consequently, performing a part of the operation in a virtual way will result in a reduction of fluoroscopy time. In the future virtual fracture reduction may contribute to optimise treatment. 
We are currently performing studies on insertion of a DHS, proximal femoral nail (PFN) and iliosacral screws based on guide wire navigation. Therefore, LED's are attached to a drillsleeve. The possibility to navigate guide wires makes procedures more intuitive and closer to the conventional operation. This may enhance safety of the procedure and implication of navigation in routine trauma care. 


\section{Reference List}

1. Hofstetter, R., Slomczykowski, M., Krettek, C., Koppen, G., Sati, M., and Nolte, L. P.: Computerassisted fluoroscopy-based reduction of femoral fractures and antetorsion correction. Comput. Aided Surg. 5:311-325, 2000.

2. Hofstetter, R., Slomczykowski, M., Sati, M., and Nolte, L. P.: Fluoroscopy as an imaging means for computer-assisted surgical navigation. Comput. Aided Surg. 4:65-76, 1999.

3. Mehlman, C. T. and DiPasquale, T. G.: Radiation exposure to the orthopaedic surgical team during fluoroscopy: "how far away is far enough?". J. Orthop Trauma. 11:392-398, 1997.

4. Rampersaud, Y. R., Foley, K. T., Shen, A. C., Williams, S., and Solomito, M.: Radiation exposure to the spine surgeon during fluoroscopically assisted pedicle screw insertion. Spine. 25:2637-2645, 2000.

5. Schep, N. W. L., van Walsum, TH., de Graaf, J. S., Broeders, I. A. M. J., and van der Werken, Chr. Validation of fluoroscopy based navigation in the hip region. HU Lemke et al. CARS 2002. Amsterdam, Elsevier sciences. 26-6-2002.

6. Slomczykowski, M. A., Hofstetter, R., Sati, M., Krettek, C., and Nolte, L. P.: Novel computer-assisted fluoroscopy system for intraoperative guidance: feasibility study for distal locking of femoral nails. J Orthop. Trauma. 15:122-131, 2001. 
Chapter

\section{Computer assisted versus conventional surgery for insertion of 96 cannulated iliosacral screws}

N.W.L.Schep1, R. Haverlag2, A.B. van Vugt2

1Department of Surgery University Medical Centre Utrecht, The Netherlands

2Department of Surgery Erasmus Medical Centre Rotterdam, The Netherlands

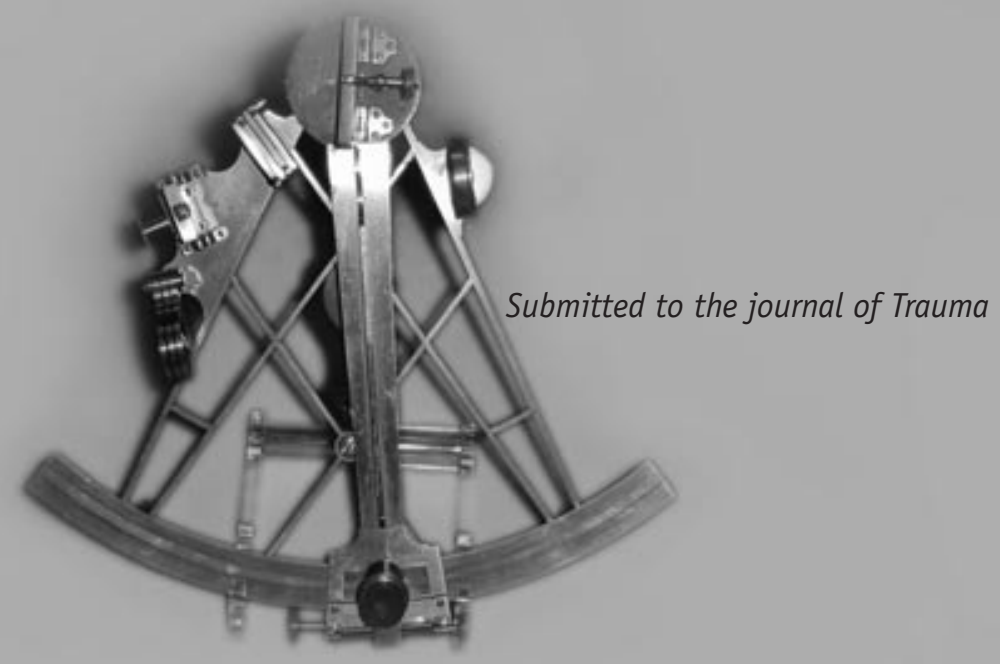




\section{Summary}

Objective: The purpose of this study was to assess the value of fluoroscopy based Computer Assisted Surgery (CAS) for the insertion of iliosacral screws. The results of CAS were compared with the results of a conventionally operated prospective control group. Endpoints of this study were fluoroscopy time, guidewire insertion time operation time and complication rate.

Patients and Methods: The study group consisted of 24 patients with post partum pelvic pain syndrome. All patients were treated with a stabilisation of the pelvic ring by means of an anterior plate fixation and autologous tricortical bone graft as well as two iliosacral screws bilaterally. Consequently, the results of 48 versus 48 iliosacral screw fixations could be evaluated. Conventionally operated patients were turned from the supine to the prone position intraoperatively, whereas CAS operated patients were operated in the supine position. One surgeon performed all operations.

Results: The fluoroscopy time in the CAS group was $0.7 \mathrm{~min}$. versus $1.8 \mathrm{~min}$. in the conventional treated group $(P<0.01)$. The mean insertion time for four guidewires was 20.2 $\mathrm{min}$ in the CAS versus $19.4 \mathrm{~min}$ in the conventional operated group $(P=0.6)$. The mean operation time in the CAS group was $97 \mathrm{~min}$. and $116 \mathrm{~min}$. in the conventional group $(P=0.03)$. In the CAS group one patient had pain and a sensory deficit of $\mathrm{S} 2$ postoperatively. The Fisher's exact test showed no difference in complication rate between the two groups $(\mathrm{P}=0.26)$.

Conclusions: This study shows that CAS is a save technique for insertion of iliosacral screws. The fluoroscopy time is decreased with a factor 2.5. The loss in operation time using CAS was due to fact that patients were operated in the supine position during the whole procedure. Guide wire insertion time was similar in both groups, however, in the future CAS may accelerate the procedure. 


\section{Introduction}

Percutaneous internal fixation of the posterior pelvic ring with iliosacral screws was originally described by Matta et al. $\left({ }^{1}\right)$ The percutaneous technique has become popular with the advent of cannulated screws and improved fluoroscopic imaging. $\left.{ }^{2,3}\right)$ Advantages of percutaneous screw fixation include minimal invasion of soft tissue, limited blood loss and decreased infection rates. $\left({ }^{3,4}\right)$ During the operation, a guidewire for the cannulated screw is drilled across the ilium and targeted in the first or second sacral vertebral body, using intraoperative fluoroscopic control.

When using intraoperative fluoroscopy, only a one single two-dimensional (2D) image plane is visualised on a specific moment. Whereas, at least three image planes, inlet, outlet and lateral are required to allow accurate insertion of the guidewires. This leads to repetitive position changes of the $\mathrm{C}$-arm intraoperatively, resulting in an important radiation exposure for both patient and surgical team. $\left({ }^{5-7}\right)$ Moreover, this technique requires a high degree of "three-dimensional thinking (3D)" and an expert knowledge of the anatomy of the pelvis. These arguments make percutaneous iliosacral screw placement a demanding operation with risk of injury of the lumbosacral nerve roots, perforation of the iliac vessels, and the peritoneal cavity. $(3,4,8-10)$

The disadvantages of the conventional technique may be solved by fluoroscopy based computer assisted surgery (CAS). With this technique the virtual position of surgical instruments is superimposed on multiple single shot radiographic images in real time. Consequently, the position and direction of a guidewire can be visualised in different fluoroscopic images simultaneously. $\left({ }^{11,12}\right)$ Hypothetically, this way of operating may result in accurate screw placement, reduction of radiation exposure and loss of operation time. Fluoroscopy based CAS for the insertion of iliosacral screws in 35 pelvic models was described by Hinsche et al. This study showed a reduction in fluoroscopy time and an accuracy equivalent with the conventional technique. $\left({ }^{12}\right)$

The purpose of this study was to assess the value of fluoroscopy based CAS for the insertion of iliosacral screws in the clinical situation. The results of CAS were compared with the results of a conventionally operated prospective control group. Endpoints of this study were fluoroscopy time, guidewire insertion time operation time and complication rate. 


\section{Patients and Methods}

To allow fluoroscopy based CAS, light emitting diodes (LED's) were attached to the C-arm (Philips BV29, Best the Netherlands), pelvis and a $3 \mathrm{~mm}$ drill sleeve. An optical tracking sensor (Polaris, Nothern Digital inc., Waterloo, Canada), overlooking the surgical field, received infrared light emitted by the LED's for position tracking. (Figure 1) After merging the positional information of the pelvis, drill sleeve and C-arm, the virtual position of the drill sleeve could be superimposed on fluoroscopic images displayed on the workstation (Stealthstation iON, Medtronic SNT, Louisville, USA).

The study group consisted of 24 patients with post partum pelvic pain syndrome. All patients were treated with a stabilisation of the pelvic ring by means of an anterior plate fixation and autologous tricortical bone graft as well as two iliosacral screws bilaterally. The long-term results of this type of operation await publication and will not be discussed in this paper (van Zwienen et al., submitted). After obtaining informed consent twelve consecutive patients were operated with fluoroscopy based CAS. The control group consisted of twelve prospective conventionally operated patients. Both patients groups were identical for age and preoperative morbidity. Consequently, the results of 48 versus 48 iliosacral screw fixations could be evaluated and compared. One surgeon performed all operations.

All conventional operated patients were turned to the prone position after the anterior approach for the plate fixation, whereas, all CAS patients were operated in the supine position. In this study the senior author ( $V$ VAB) performed all operations. During the conventional procedure guidewire insertion was performed under fluoroscopic control. For the CAS procedure single inlet, outlet and lateral pelvic images were loaded into the workstation. After length calibration of the drill sleeve, its virtual counterpart was enlarged to $200 \mathrm{~mm}$ with a diameter of $3 \mathrm{~mm}$. to visualise the position and direction of the guidewire in all three fluoroscopic images. This made it possible to determine the correct position for the stab incision.

After incision the drill sleeve was advanced to the cortex of the os ilium. When the drill sleeve touched the bone the appropriate position and length of the virtual guidewire was chosen. (Figure 2) The penetrating part of a $3 \mathrm{~mm}$ guidewire was measured the same length as the virtual guidewire and was attached to a drilling machine. Subsequently, it was inserted through the drill sleeve. After $45 \mathrm{~mm}$ insertion of the first guidewire, just before reaching the transforaminal "danger zone" fluoroscopic inlet, outlet and lateral control images were obtained. When the position of the virtual guidewire matched the position 
of the guidewire in the fluoroscopic images the procedure was continued using CAS. Every time a guidewire was positioned its virtual position was drawn in the fluoroscopic images. (Figure 3) When, all four guidewires were positioned, $6.5 \mathrm{~mm}$ cannulated screws (Biomet, Warsaw, USA) were inserted and correct positioning of the screws was confirmed with fluoroscopy. Only a small number of patients were treated with screws positioned in the second sacral vertebral body, two screws in the CAS and eight screws in the conventional group.

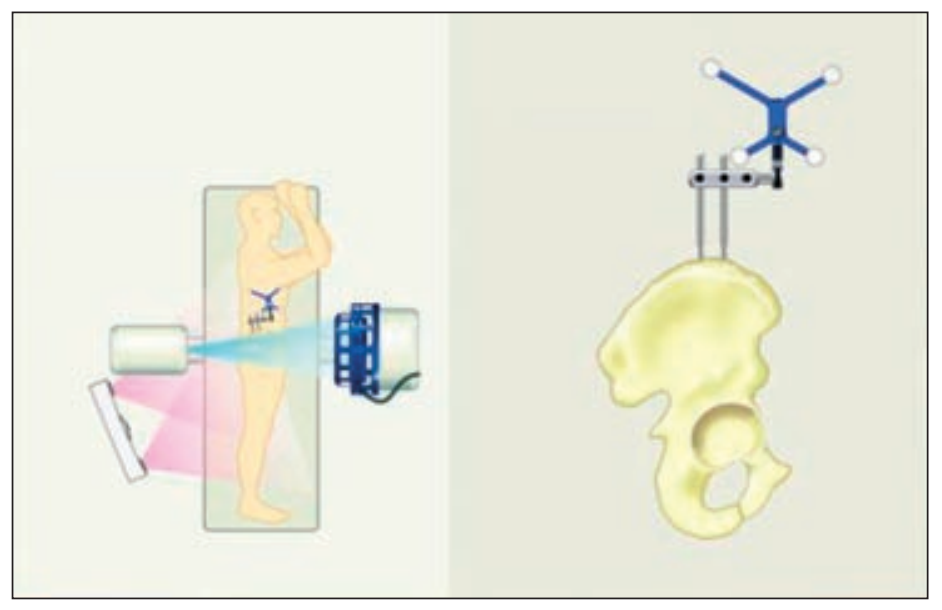

Figure 1A

An optical tracking sensor

(Polaris, Nothern Digital

inc., Waterloo, Canada),

overlooking the surgical field,

received infrared light emitted

by the LED's for position

tracking. LED's were fixated

on the pelvis, C-arm and drill sleeve.

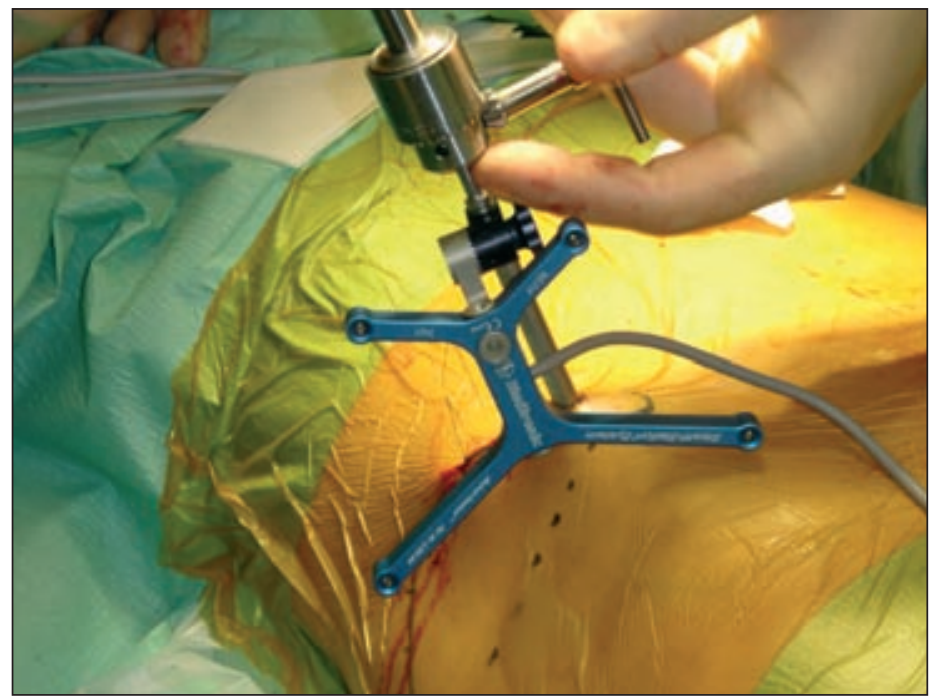

Figure 1B

The patients reference frame is firmly attached in the pelvis. 


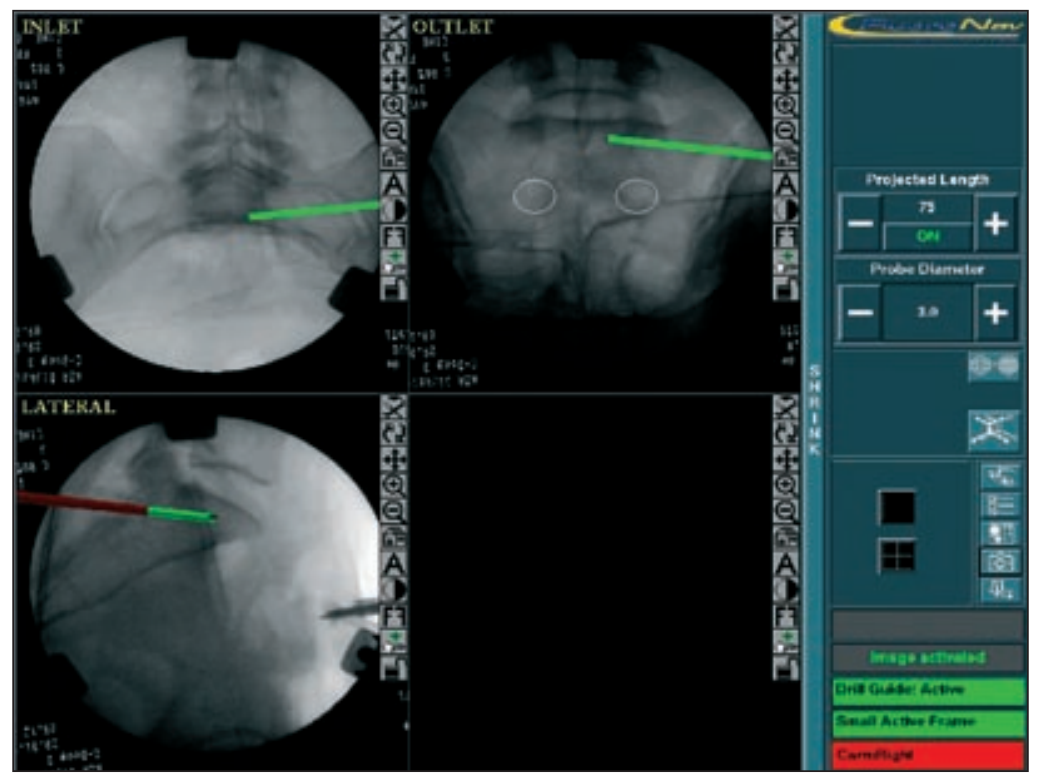

Figure 2

When the drill sleeve touched the bone the appropriate position and length of the virtual guidewire was chosen. The penetrating part of a $3 \mathrm{~mm}$ guidewire was measured the same length as the virtual guidewire in this example $75 \mathrm{~mm}$. The white circles indicate the position of both foramina.

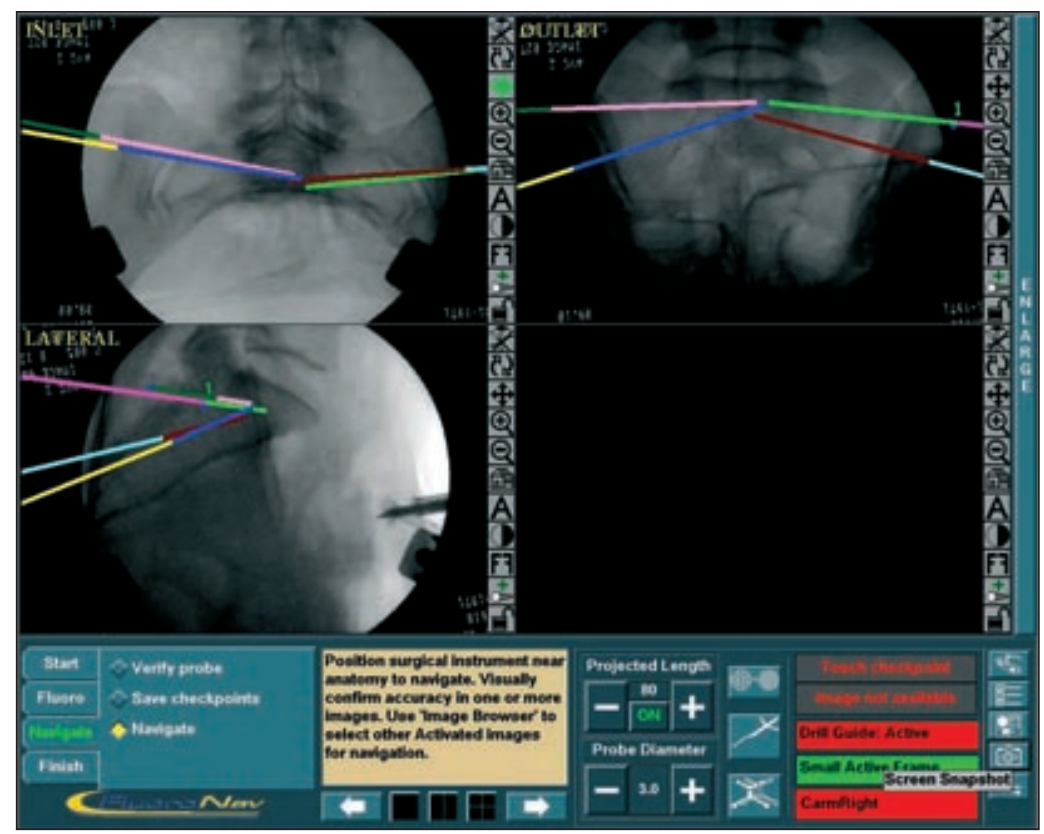

Figure 3

Every time a guidewire was positioned its virtual counterpart was drawn in the fluoroscopic images. 
Intraoperatively, system set up time, fluoroscopy time, guidewire insertion time and total operation time were scored. The operation time was defined from the skin incision for the anterior internal fixation until suturing was completed. Postoperatively the patients were followed up for operation related complications. The time period for these complications to occur was defined within 30 days after surgery.

All results were evaluated with SPSS 10.1 for Windows (SPSS, Inc, Chicago). A Mann Whitney test was performed to test the hypothesis of no difference in fluoroscopy time, guidewire insertion time and total operation time. $\mathrm{P}<0.05$ was considered significant. Differences in complication ratio were evaluated with the Fisher's exact test.

\section{Results}

In the conventional and in the CAS group the average age was 36 years (range 26-47 years). The mean system setup time was $7.8 \mathrm{~min}$. (range 5-17 min.). The fluoroscopy time in the CAS group showed to be $0.7 \mathrm{~min}$. versus $1.8 \mathrm{~min}$. in the conventional treated group $(P<0.01)$. The mean insertion time for four guidewires was $20.2 \mathrm{~min}$ in the CAS versus $19.4 \mathrm{~min}$ in the conventional operated group $(\mathrm{P}=0.6)$. The mean operation time in the CAS group was $97 \mathrm{~min}$. and 116 min. in the conventional group ( $\mathrm{P}=0.03)$.

In the CAS group one patient had pain and a sensory deficit of S2 postoperatively. The control CT scan showed a marginal protrusion of the screw treads into the sacral canal of S2. After the screw was extracted the complaints resolved completely. A total of three patients developed a complication in the conventional group. Two patients had a posterior hematoma. In one of these cases a reoperation was indicated. The other patient had a postoperative sensory deficit, which resolved completely without intervention. The Fisher's exact test showed no difference in complication rate between the two groups $(P=0.26)$.

\section{Discussion}

Fluoroscopy based navigation is an upcoming technology in orthopaedic and trauma surgery since 1999. The purpose of this study was to assess the value of fluoroscopy based CAS for the insertion of iliosacral screws in the clinical situation. The results of the CAS procedure were compared with the results of a conventionally operated prospective control group. 
The learning curve for system set-up was short and after three procedures the set-up time ranged between five and eight minutes. System set-up was performed during intubation of the patient and therefore did not influence the total operation time.

When using fluoroscopy based CAS a limited number of fluoroscopic images is acquired. This resulted in a reduction of fluoroscopy time with a factor of almost 2.5. In this study the position of the guidewires and additionally the position of the screws was verified with the $\mathrm{C}$-arm during the operation. This was done as an accuracy check. However, in none of the cases there was a discrepancy between the virtual position and the actual position of the guidewire. When surgeons learn to rely on the navigation system and the accuracy check is omitted, fluoroscopy time will become even less than the average of $0.7 \mathrm{~min}$. as revealed in this study.

The mean insertion time for four guidewires was similar in both groups. The surgeon who performed all operations was very experienced in iliosacral screw fixation, which may have moderated the influence of CAS on the targeting process. Secondary, the CAS procedure was slightly prolonged due to the additional fluoroscopic safety control before reaching the transforaminal zone.

The mean operating time was almost 20 minutes less in the CAS group compared with the conventional operated patients. All conventional operated patients were turned to the prone position after the anterior approach, whereas all CAS patients were operated in the supine position during the whole procedure. This intraoperative rotation and consequently additional draping is the explanation for the 20 minutes extra operating time in the conventional treated group.

One screw in the CAS group, positioned in the second sacral vertebral body, was malpositioned causing a sensory deficit of S2 postoperatively. The control CT scan showed marginal protrusion of the screw treads into the sacral canal of S2. All surgical navigation systems are known to have a certain inaccuracy. Most systems recommend a safety margin of $2 \mathrm{~mm}$, which is sufficient in the majority of cases. ${ }^{13}$ In this particular case the bony bridge between S1 and S2 was very small which led to abandonment of the $2 \mathrm{~mm}$ safety margin. An earlier study already showed that screws positioned in the first sacral body have a significantly lower incidence of neurological deficit compared with screws positioned in the second sacral body. ${ }^{14}$ However, no difference in complication rate between the two operation techniques could be objectified.

This study shows that fluoroscopy based CAS is a save and intuitive technique for performing posterior pelvic screw fixation. The fluoroscopy time is decreased with a factor 2.5 using the navigation system. Using a navigation system does not lead to an increase of procedure time and may in the future even accelerate the procedure 


\section{Reference List}

1. Matta, J. M. and Saucedo, T.: Internal fixation of pelvic ring fractures. Clin. Orthop.83-97, 1989.

2. Routt, M. L., Meier M., and Kregor, P. J.: Percutaneous iliosacral screws with the patient supine technique. Oper Tech Orthop.35-45, 1993.

3. Routt, M. L., Jr., Kregor, P. J., Simonian, P. T., and Mayo, K. A.: Early results of percutaneous iliosacral screws placed with the patient in the supine position. J. Orthop. Trauma. 9:207-214, 1995.

4. Shuler, T. E., Boone, D. C., Gruen, G. S., and Peitzman, A. B.: Percutaneous iliosacral screw fixation: early treatment for unstable posterior pelvic ring disruptions. J. Trauma. 38:453-458, 1995.

5. Mehlman, C. T. and DiPasquale, T. G.: Radiation exposure to the orthopaedic surgical team during fluoroscopy: “how far away is far enough?". J. Orthop Trauma. 11:392-398, 1997.

6. Sanders, R., Koval, K. J., DiPasquale, T., Schmelling, G., Stenzler, S., and Ross, E.: Exposure of the orthopaedic surgeon to radiation. J. Bone Joint Surg. Am. 75:326-330, 1993.

7. Rampersaud, Y. R., Foley, K. T., Shen, A. C., Williams, S., and Solomito, M.: Radiation exposure to the spine surgeon during fluoroscopically assisted pedicle screw insertion. Spine. 25:2637-2645, 2000.

8. Ebraheim, N. A., Coombs, R. J., Hoeflinger, M. J., and Jackson, W. T.: A pitfall of radiologic evaluation of sacroiliac joint screw positioning. Orthopedics. 16:616-618, 1993.

9. Pattee, G. A., Bohlman, H. H., and McAfee, P. C.: Compression of a sacral nerve as a complication of screw fixation of the sacro-iliac joint. A case report. J. Bone Joint Surg. Am. 68:769-771, 1986.

10. Templeman, D., Schmidt, A., Freese, J., and Weisman, I.: Proximity of iliosacral screws to neurovascular structures after internal fixation. Clin. Orthop.194-198, 1996.

11. Hofstetter, R., Slomczykowski, M., Sati, M., and Nolte, L. P.: Fluoroscopy as an imaging means for computer-assisted surgical navigation. Comput. Aided Surg. 4:65-76, 1999.

12. Hinsche, A. F., Giannoudis, P. V., and Smith, R. M.: Fluoroscopy-based multiplanar image guidence for insertion of sacroiliac screws. Clin. Orthop. 395:135-144, 2001.

13. Schep, N. W. L., van Walsum, TH., de Graaf, J. S., Broeders, I. A. M. J., and van der Werken, Chr. Validation of fluoroscopy based navigation in the hip region. HU Lemke et al. CARS 2002, Springer Berlin, 247-251

14. van den Bosch, E. W., van Zwienen, C. M., and van Vugt, A. B.: Fluoroscopic positioning of sacroiliac screws in 88 patients. J. Trauma. 53:44-48, 2002. 
Chapter

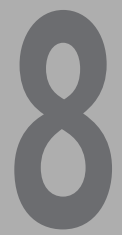

\section{General discussion and conclusions}

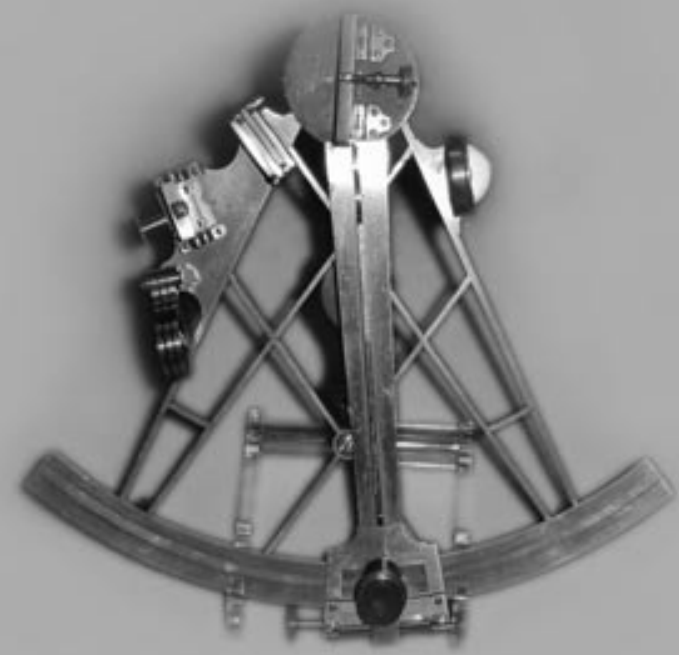




\section{Discussion}

Computer Assisted Surgery (CAS) is currently considered a standard of care in neurosurgery. Neurosurgeons use this technique to facilitate intracranial needle biopsies, isotope implantation and tumour resection. $\left(^{2 ; 3 ; 9 ; 20 ; 21}\right)$ Theoretically, Orthopaedic and Trauma surgery are also well suited for this technique. Brain tissue may deform during manipulation by the surgeon. This intra-operative change of anatomy caused by manipulation is an important problem during CAS in neurosurgery. Bone tissue, however, is almost not deformable and therefore is very appropriate for CAS, based on pre- or intra-operatively obtained images.

In CAS improved visualisation is combined with computer tracking of surgical instruments. This feature promises enhanced accuracy and consequently less morbidity combined with a reduction in radiation exposure.

The goal of this thesis was to evaluate the hypothesis of high accuracy and reproducibility of CAS. This was achieved by performing a series of tests. All tests were performed within an experimental and clinical setting. To test the hypothesis the following questions were answered.

1. How exact represents the displayed position of an instrument in fluoroscopic images the real situation?

2. Does CAS reduce surgical variance and therewith improve the reproducibility of (minimal invasive) orthopaedic and trauma surgery ?

3. Are there clinical benefits using CAS during positioning of implants?

\section{How exact represents the displayed position of an instrument in fluoroscopic images the real situation?}

Fluoroscopic images are frequently used for navigation within bone tissue. During CAS the position of tracked instruments is superimposed on these fluoroscopic images after image acquisition $\left({ }^{11}\right)$

Surgeons using this technique have to rely on the accuracy of the navigation system, since the only intraoperative feedback on the "true" position of the instrument is the position of its virtual counterpart superimposed on the fluoroscopic images. Lack of correspondence between this virtual position and the true position may lead to severe complications. 
In Chapter 3 the accuracy of the fluoroscopy based navigation system used in our hospital (Medivision, Oberdorf, $\mathrm{CH}$.) was evaluated in a laboratory study performed in 20 sawbones of a proximal femur. The displayed virtual position of a reamer within the fluoroscopic images was compared with its true position in a predefined cutplane in the middle of the femoral neck. The virtual position of the reamer appeared to be reliable in $97 \%$ of cases when considering an inaccuracy of $\leq 2 \mathrm{~mm}$ as clinically irrelevant. In nine out of 360 measurements a difference of more than $2 \mathrm{~mm}$ was found. In these cases it seemed most likely that the Dynamic Reference Frame (DRF) was moved relative to the sawbone during the experiment. In conclusion, the fluoroscopy based navigation system that was validated in this study provided a reliable virtual position of the reamer in the femoral neck compared with its true position. When a firm connection between the DRF and the target bone is assured the system can be safely used.

\section{Does CAS reduce surgical variance and therewith improve the reproducibility of (minimal invasive) orthopaedic and trauma surgery ?}

An important objective of CAS is to improve the reproducibility of a procedure. To achieve this goal it will be necessary to reduce surgical variance between surgeons, performing identical operations. In the experimental part of our study we tested the hypothesis that CAS enhances reproducibility in the treatment of femoral shaft fractures and ACL graft placement.

\section{Computer assisted anteversion and length control in closed nailing of femoral shaft fractures}

Locked intramedullary nailing is commonly used for the treatment of femoral shaft fractures. An important complication of the conventional limited invasive nailing procedure is malrotation of the stabilised femur. Rotation differences of $15^{\circ}$ or more were found in $19 \%$ and leg length discrepancies of more than $10 \mathrm{~mm}$ in $9 \%$ of patients. $(4 ; 5)$ Hofstetter and others developed a CAS module for the surgical treatment of femoral shaft fractures. $\left({ }^{10}\right)$ This concept allows intraoperative assessment and control of rotation and length. Potential advantages of this technique are reduction of postoperative torsion deformities and leg length discrepancies. Chapter 4 presents the results of a cadaver study investigating the reliability and reproducibility of femoral anteversion angles and lengths provided by the navigation system (Medivision, Oberdorf, $\mathrm{CH}$.). 
To determine the rotation and length of the femoral shaft different landmarks were manually defined in six fluoroscopic images displayed on the CAS system. This was performed for each femur by three investigators. To evaluate the anteversion angels and femoral lengths provided by the navigation system, a golden standard based on CT data was developed. The golden standard allowed navigation through coronal, sagittal and axial planes. The three investigators defined the same landmarks as in the fluoroscopic images. Inter observer variability was assessed for the fluoroscopy (CAS) and CT based method.

The mean inter investigator variance using the CAS method was $5.5^{\circ}$ (1-11) for anteversion and $5.2 \mathrm{~mm} \mathrm{(2-10)}$ for femoral length. The CT based method showed a mean inter investigator variance of $3.1^{\circ}(0.41-7.97)$ for anteversion and $2.5 \mathrm{~mm}(0.78-5.94)$ for length. The mean difference in length measurements between the CAS and CT based method was $<1 \mathrm{~cm}$. The variation in measured anteversion angles between the CAS and CT based method showed a mean difference of $13^{\circ}$ degrees with a maximum $26^{\circ}$.

In summary the length measurements provided by the navigation system showed to be reproducible and accurate enough for clinical use. The rotation measurements were reproducible with a difference of almost six degrees but not accurate enough to prevent malrotation considering the CT based method as the gold standard. When using the anteversion angle of the contralateral (unbroken) extremity as a template for the reduction the inter investigator variance may be enough to avoid outliers. This will be the subject for further research.

\section{Computer assisted anterior cruciate ligament graft positioning}

The most critical step in arthroscopic reconstruction of a torn anterior cruciate ligament $(A C L)$ with a (patellar tendon) graft is placement of the femoral and tibial tunnels, in which the graft is secured. An accurate position of these tunnels can minimise stretching of the graft and decrease the risk of impingement against the roof of the femoral notch during extension of the knee. $\left({ }^{1}\right)$ Graft over stretching and impingement may lead to graft failure. $(22)$

Desenne et al. introduced a computer system to predict notch impingement and graft elongation. $\left({ }^{6}\right)$ Intraoperatively, the surgeon defined the femoral and tibial attachment sides of the graft. Subsequently, the computer created a virtual model of the knee. Notch impingement and elongation for selected graft positioning could be predicted by displaying the kinematics of a virtual ACL on a monitor, before the actual drilling of the tunnels. $\left({ }^{18}\right)$ Theoretically, this way of virtual planning should reduce the variance between surgeons and leads to a more accurate and reproducible procedure. In Chapter 5 this hypothesis was 
tested and inter- surgical variance was assigned in mm. Next, computer assisted virtual planning was compared with a conventional procedure in the same knee.

Three surgeons with a different experience level participated. Computer assisted ACL planning was compared between two surgeons in the same cadaver knee. The computer system outlined an impingement area and visualised graft elongation in a virtual manner. Both surgeons positioned the virtual graft in such a way that impingement was avoided and graft elongation was $<4 \mathrm{~mm}$ during flexion and extension. A third surgeon performed a conventional procedure on the same cadaver knee. The position and kinematics of this graft were also analysed with the computer system.

The difference between the two planning procedures proved to be approximately $5 \mathrm{~mm}$ in both tibia and femur. The experience level of the surgeon had no effect on the position of these virtual tunnels. The mean distance between the planned and the conventional procedures proved to be more than six $\mathrm{mm}$ for both the tibia as the femoral tunnel. The conventional procedure showed impingement in three out of twelve knees and an elongation of more than four $\mathrm{mm}$ in two additional knees. The less experienced surgeon was responsible for two impingement cases. The three knees with an elongation of more than four mm were equally distributed among the three surgeons.

This study indicates that computer assisted planning may reduce the inter-surgical variance to $5 \mathrm{~mm}$ for positioning both tunnels. Moreover, the experience level of the surgeon did not effect the planning process. Less experienced surgeons and residents may benefit from virtual graft planning to reduce the number of malpositioned tunnels.

\section{Are there clinical benefits using CAS during positioning of implants?}

The results of the accuracy study described in Chapter 3 led to the clinical implementation of fluoroscopy based navigation for internal fixation of femoral neck fractures with a Dynamic Hip Screw (DHS). This type of operation was selected because it is a relative simple and frequently performed procedure and therefore well suited to gain clinical experience.

Additionally, the clinical value of fluoroscopy based CAS for the insertion of iliosacral screws was evaluated. The results of CAS iliosacral screw fixation were compared with the results of a conventionally operated prospective control group. 
General discussion and conclusions

Internal fixation of femoral neck fractures with computer assisted surgery

Chapter 6 describes the feasibility and pitfalls of CAS in the treatment of femoral neck fractures with a DHS in a small patients group. After the accuracy study we treated seven patients to evaluate the feasibility of this new technique.

All seven patients were operated in supine position on a fracture table. After closed reduction of the fracture the injured leg was brought in slight traction. In four patients the DRF was attached rigidly with a Steinmann pin in the iliac crest and in three patients in the greater trochanter. Subsequently, AP and AX fluoroscopic images were obtained and loaded into the workstation (Medivision, Oberdorf, Switzerland).

To achieve CAS in the hip region two standard instruments were modified. First, a procedure dedicated aiming arm was designed, based on the standard $135^{\circ}$ aiming device, holding an $8 \mathrm{~mm}$ channel for the DHS reamer. This enabled the surgeon to drill directly in the correct angle. Secondly, the standard cannulated $8 \mathrm{~mm}$ DHS reamer was made non-cannulated by fixating a K-wire in the central hole, which exceeded the tip of the drillbit by two $\mathrm{mm}$. The tip of this K-wire was pressed in the lateral femoral cortex just before drilling, establishing better grip on the lateral femoral cortex. After drilling the insertion hole, the hip screw and a one hole $135^{\circ}$ side plate were inserted by standard technique.

One CAS procedure failed because the position and direction of the virtual drill undoubtedly did not correspond with the true anatomic position of the drillbit. In the first four patients we tested the hypothesis that traction of the affected limb could establish a rigid relation between the pelvis and proximal femur. Therefore, the DRF was attached in the iliac crest. This made it simple to obtain a straight line of sight between the opto-electric camera and the DRF's of the DRF during image acquisition and drilling. However, non-correspondence between the virtual drill and the clinical situation in the patient, described above, made it clear that during manipulation this fixed relationship could not be guaranteed in all situations. This example emphasizes once more that it is obligatory to fix the patient's DRF in the operated bone.

In one patient the tip of the hip screw was positioned to deeply in the femoral head. In retrospect, it was not possible to clearly identify the contours of the femoral head on the uploaded fluoroscopic images. Moreover, in this set up the surgeon had to drill instantaneously through an $8 \mathrm{~mm}$ aiming device. In clinical practice it seemed to be complex to hold the aiming device and the drilling machine while at the same time maintaining enough pressure on the lateral femoral cortex. Repeatedly, the drill slid from the lateral femoral cortex. The absence of a K-wire can be held responsible for this dilemma. 
Our limited experience showed that fluoroscopy based navigation in the treatment of femoral neck fractures with a DHS is feasible. However, the technique used in this study was to complicated to use in daily practice. The possibility to navigate guidewires will probably make the procedure more intuitive and closer to the conventional operation.

Computer assisted surgery for insertion of cannulated iliosacral screws

In Chapter 7 fluoroscopy based CAS for the insertion of iliosacral screws was evaluated. Working with CAS may offer additional benefits as reduction in operation time and radiation exposure. To test this hypothesis the results of CAS were compared with the results of a conventionally operated prospective control group. Endpoints of this study were fluoroscopy time, guidewire insertion time and complication rate.

The operative results of 48 versus 48 identical patients with post partum pelvic pain syndrome were evaluated. All patients were treated with a stabilisation of the pelvic ring by means of symphysal plating combined with an autologous tricortical bone graft as well as two iliosacral screws bilaterally.

With the CAS technique used in this study (Stealthstation iON, Medtronic SNT, Louisville, USA) it was possible to visualise the position and direction of a guidewire in three fluoroscopic images (inlet, outlet, lateral).

Fluoroscopy time was decreased with a factor of 2.5 in the CAS group (mean 0.7 min.). The mean insertion time for four guidewires was similar in both groups. However, during the CAS procedure an additional fluoroscopic safety control was performed before reaching the transforaminal zone. During these safety checks no discrepancy between the virtual position and the actual position of the guidewire was confirmed. No difference in complication rate between the two operation techniques could be objectified.

This study showed that fluoroscopy based CAS is a save and intuitive technique for performing posterior pelvic screw fixation. The fluoroscopy time was decreased with a factor 2.5. The use of the navigation system did not lead to a longer procedure time and may in the future even accelerate the procedure when the intraoperative safety check is omitted.

\section{Conclusions}

The potential advantages of Computer Assisted Surgery (CAS) are obvious, increasing the accuracy, safety and reproducibility of surgical interventions. Moreover, CAS technologies 
offer additional benefits as lower radiation exposure through navigation in one shot fluoroscopic images.

This thesis showed that fluoroscopy based surgical navigation is accurate enough to use in experimental and clinical situations. The position of a surgical instrument can be displayed virtually within fluoroscopic images of bone tissue with less than $2 \mathrm{~mm}$ inaccuracy in $97 \%$ of the cases.

However, when CAS was used to treat simple femoral neck fractures with a DHS the surgeons encountered several technical hitches. They had to operate with different and modified instruments to create an environment, which allowed surgical navigation in the proximal femur. The result was a feasible procedure that was, however, inadequate for daily clinical practice. This study clearly showed that CAS has to be intuitive and easy to use before it is embedded in standard surgical practice.

In fracture care the positioning of guidewires is a frequently performed procedure when performing osteosynthesis. Navigation of guidewire insertion led to an intuitive and straightforward procedure in iliosacral screw fixation. This was shown when the results of CAS iliosacral screw fixation were compared with those in a conventionally operated control group. Important benefits of the computer-assisted procedure were revealed in this study: fluoroscopy time was shortened with a factor 2.5, CAS facilitated the targeting process in diverse image planes while it is reasonable to expect that CAS will accelerate this procedure in the future.

The results of the experimental studies described in this thesis show an opportunity to influence surgical variance in a positive way. CAS for intramedullary fixation of femoral shaft fractures offers the opportunity to exactly locate the insertion point for the nail on the proximal femur and to perform distal locking effectively. However, computer assisted anteversion control as described in our study is not yet evolved to the stage of save clinical implementation.

Considering, computer-assisted planning of an $\mathrm{ACL}$ graft, it was shown that surgical variance is about five $\mathrm{mm}$ for the tunnels both in the femur and tibia. Whether this accuracy is enough to reduce the outliers and to reach a better clinical outcome in ACL reconstruction is uncertain.

Image guided surgical navigation will become standard in various fields of orthopaedic and trauma surgery in the future. These fields will be most likely pedicle screw placement in spine surgery, sacroiliacal fixation, reduction of long bone fractures and knee and hip prosthetic replacement. Navigation based on 3D fluoroscopic images is the latest technology and will lead to new clinical applications. 
In summary fluoroscopy based CAS is accurate enough to rely on in experimental and clinical situations. This thesis proved several clinical benefits for CAS when used for navigated guidewire insertion in iliosacral screw fixation compared with the conventional technique. The CAS femoral anteversion control module must be improved before clinical use. Computer-assisted ACL grafting has to be evaluated in a controlled study. However, it is to be expected that CAS will soon evaluate into a clinically accepted and mandatory technique in some fields of orthopaedic and trauma surgery. 


\section{Reference List}

1. Amis, A. A. and Jakob, R. P.: Anterior cruciate ligament graft positioning, tensioning and twisting. Knee. Surg. Sports Traumatol. Arthrosc. 6 Suppl 1:S2-12, 1998.

2. Apuzzo, M. L. and Sabshin, J. K.: Computed tomographic guidance stereotaxis in the management of intracranial mass lesions. Neurosurgery. 12:277-285, 1983.

3. Barnett, G. H., Kormos, D. W., Steiner, C. P., and Weisenberger, J.: Use of a frameless, armless stereotactic wand for brain tumor localization with two-dimensional and three-dimensional neuroimaging. Neurosurgery. 33:674-678, 1993.

4. Braten, M., Terjesen, T., and Rossvoll, I.: Torsional deformity after intramedullary nailing of femoral shaft fractures. Measurement of anteversion angles in 110 patients. J. Bone Joint Surg. Br. 75:799-803, 1993.

5. Braten, M., Terjesen, T., and Rossvoll, I.: Femoral shaft fractures treated by intramedullary nailing. A follow-up study focusing on problems related to the method. Injury. 26:379-383, 1995.

6. Dessenne, V., Lavallee, S., Julliard, R., Orti, R., Martelli, S., and Cinquin, P.: Computer-assisted knee anterior cruciate ligament reconstruction: first clinical tests. J. Image Guid. Surg. 1:59-64, 1995.

7. Fineberg, M. S., Zarins, B., and Sherman, 0. H.: Practical considerations in anterior cruciate ligament replacement surgery. Arthroscopy. 16:715-724, 2000.

8. Frank, C. B. and Jackson, D. W.: The science of reconstruction of the anterior cruciate ligament. J. Bone Joint Surg. Am. 79:1556-1576, 1997.

9. Gildenberg, P. L., Kaufman, H. H., and Murthy, K. S.: Calculation of stereotactic coordinates from the computed tomographic scan. Neurosurgery. 10:580-586, 1982.

10. Hofstetter, R., Slomczykowski, M., Krettek, C., Koppen, G., Sati, M., and Nolte, L. P.: Computerassisted fluoroscopy-based reduction of femoral fractures and antetorsion correction. Comput. Aided Surg. 5:311-325, 2000.

11. Hofstetter, R., Slomczykowski, M., Sati, M., and Nolte, L. P.: Fluoroscopy as an imaging means for computer-assisted surgical navigation. Comput. Aided Surg. 4:65-76, 1999.

12. Kamimura, M., Ebara, S., Itoh, H., Tateiwa, Y., Kinoshita, T., and Takaoka, K.: Accurate pedicle screw insertion under the control of a computer-assisted image guiding system: laboratory test and clinical study. J. Orthop. Sci. 4:197-206, 1999.

13. Laine, T., Lund, T., and Ylikoski, M. Pedicle screw insertion with and without Computer AssistenceTwo year clinical results of a randomised controlled study in 100 patients. 2002.

14. Laine, T., Schlenzka, D., Makitalo, K., Tallroth, K., Nolte, L. P., and Visarius, H.: Improved accuracy of pedicle screw insertion with computer-assisted surgery. A prospective clinical trial of 30 patients. Spine. 22:1254-1258, 1997.

15. Ludwig, S. C., Kramer, D. L., Balderston, R. A., Vaccaro, A. R., Foley, K. F., and Albert, T. J.: Placement of pedicle screws in the human cadaveric cervical spine: comparative accuracy of three techniques. Spine. 25:1655-1667, 2000.

16. Merloz, P., Tonetti, J., Eid, A., Faure, C., Lavallee, S., Troccaz, J., Sautot, P., Hamadeh, A., and Cinquin, P.: Computer-assisted spine surgery. Clin. Orthop.86-96, 1997.

17. Merloz, P., Tonetti, J., Pittet, L., Coulomb, M., Lavallee, S., and Sautot, P.: Pedicle screw placement using image guided techniques. Clin. Orthop.39-48, 1998.

18. sati, M., Staubli, H. U., Bourquin, Y., Kunz, M., Kasermann, S., and Nolte, L. P.: Clinical integration of computer-assisted technology for arthroscopic anterior cruciate ligament reconstruction. Operat Tech Orthopaed.40-49, 2000. 
19. Schwarzenbach, 0., Berlemann, U., Jost, B., Visarius, H., Arm, E., Langlotz, F., Nolte, L. P., and Ozdoba, C.: Accuracy of computer-assisted pedicle screw placement. An in vivo computed tomography analysis. Spine. 22:452-458, 1997.

20. Tan, K. K., Grzeszczuk, R., Levin, D. N., Pelizzari, C. A., Chen, G. T., Erickson, R. K., Johnson, D., and Dohrmann, G. J.: A frameless stereotactic approach to neurosurgical planning based on retrospective patient-image registration. Technical note. J. Neurosurg. 79:296-303, 1993.

21. Watanabe, E., Watanabe, T., Manaka, S., Mayanagi, Y., and Takakura, K.: Three-dimensional digitizer (neuronavigator): new equipment for computed tomography-guided stereotaxic surgery. Surg. Neurol. 27:543-547, 1987.

22. Zavras, T. D., Race, A., Bull, A. M., and Amis, A. A.: A comparative study of 'isometric' points for anterior cruciate ligament graft attachment. Knee. Surg. Sports Traumatol. Arthrosc. 9:28-33, 2001. 


\section{Samenvatting en conclusies}


Piloten vertrouwen voor een belangrijk deel op hun visuele waarneming tijdens het landen van een vliegtuig. Wanneer slechte weersomstandigheden het zicht beperken vertrouwen ze op hun navigatie-instrumenten voor oriëntatie en een veilige landing. Minimaal invasieve orthopedische en traumatologische ingrepen kunnen worden vergeleken met het vliegen door dikke mist omdat de chirurg werkt door kleine openingen in het menselijk lichaam. Hierdoor gaat het directe zicht op het operatiegebied en dus op de positie van de instrumenten verloren. In deze situaties vertrouwd de chirurg op radiologische hulpmiddelen zoals computer tomography (CT), magnetic resonance imaging (MRI) en röntgendoorlichting.

Nadeel van deze technieken is dat positie van de instrumenten alleen wordt getoond op het moment van beeldvorming. Dit wil zeggen dat de chirurg een momentopname te zien krijgt. Continue beeldvorming is technisch complex en gaat gepaard met een hoge stralingsbelasting voor zowel patiënt als chirurgisch team. Tussen de momenten van beeldvorming in moet de chirurg vertrouwen op zijn of haar kennis van de anatomie en driedimensionale oriëntatie. Deze situatie kan leiden tot onnauwkeurigheid en gerelateerde morbiditeit. Het gebrek aan constante feedback over de instrumentpositie kan tevens leiden tot een verminderde reproduceerbaarheid van identieke chirurgische ingrepen.

Om een omgeving te creëren waarin chirurgen constant geïnformeerd zijn over de positie van hun instrumenten in relatie tot de anatomie werden computers geïntroduceerd in de operatiekamer. Deze manier van opereren wordt computer geassisteerde chirurgie (CAS) ofwel navigatiechirurgie genoemd. CAS informeert de chirurg op ieder moment van de operatie over de exacte positie van het instrumentarium ten opzichte van de anatomie. $0 p$ deze manier weet de chirurg ten allen tijde waar hij of zij zich bevindt. $0 \mathrm{~m}$ dit mogelijk te maken wordt de positie van het instrumentarium virtueel weergeven in radiologische beelden. Het concept is te vergelijken met een global positioning system (GPS) wat gebruikt wordt in de auto-industrie. De radiologische beelden dienen hier als de landkaart waarin de positie van een instrument virtueel wordt weergegeven. Het potentiële voordeel van deze manier van werken is een toegenomen nauwkeurigheid en een toegenomen reproduceerbaarheid van chirurgische ingrepen.

Het doel van dit proefschrift was het evalueren van de hypothese dat CAS nauwkeuriger is en leidt tot een toegenomen reproduceerbaarheid in combinatie met een lagere stralingsbelasting voor patiënt en chirurgisch team. Dit werd bereikt door het beantwoorden van de volgende vragen gedurende experimenteel en klinisch onderzoek. 
1. Hoe exact komt de virtueel afgebeelde positie van een instrument in röntgen doorlichtingbeelden overeen met de werkelijke situatie?

2. Reduceert CAS de chirurgische variatie en verbeterd daarmee de reproduceerbaarheid van (minimaal invasieve) orthopedische en traumatologische ingrepen?

3. Zijn er klinische voordelen wanneer CAS gebruikt wordt voor het positioneren van implantaten?

\section{Hoe exact komt de virtueel afgebeelde positie van een instrument in röntgen doorlichtingbeelden overeen met de werkelijke situatie?}

In hoofdstuk 3 wordt de nauwkeurigheid van het navigatiesysteem wat gebruikt wordt in ons ziekenhuis (Medivision, Oberdorf, Zwitserland) geëvalueerd. Dit werd bereikt door middel van een laboratoriumstudie in 20 plastic modellen van het proximale femur. De virtueel afgebeelde positie van een boor werd vergeleken met de werkelijke positie. Deze positie bleek betrouwbaar in $97 \%$ van de gevallen wanneer er vanuit werd gegaan dat een afwijking kleiner dan 2 mm klinisch niet relevant was. In 9 van 360 metingen was het verschil tussen de afgebeelde en werkelijke positie van de boor meer dan 2 $\mathrm{mm}$. Deze onnauwkeurigheid werd veroorzaakt doordat het dynamische referentieframe was bewogen. Dit frame wordt aan het bot gefixeerd en staat in contact met de navigatiecomputer. $0 p$ deze manier peilt de navigatiecomputer de positie van het bot. Wanneer er sprake is van een niet rigide fixatie wordt deze positiebepaling en dus de gehele procedure inaccuraat.

Deze studie laat zien dat CAS op basis van röntgen doorlichtingbeelden betrouwbaar is. Wanneer een rigide positie van het referentieframe gegarandeerd is kan dit systeem veilig in de kliniek gebruikt worden. 


\section{Reduceert CAS de chirurgische variatie en verbeterd daarmee de reproduceerbaarheid van (minimaal invasieve) orthopedische en traumatologische ingrepen?}

In het experimentele gedeelte van dit proefschrift werd de hypothese getest dat CAS leidt tot een grotere reproduceerbaarheid in de behandeling van femurschacht fracturen en plaatsing van een voorste kruisband plastiek.

Computer geassisteerde rotatie en lengte controle bij de behandeling van femurschacht fracturen.

CAS maakt het mogelijk de lengte en rotatie van het femur te bepalen tijdens het inbrengen van een intramedullaire pen. In hoofdstuk 4 worden deze rotatie en lengte metingen geëvalueerd.

Het betrof een studie in een tiental verse kadavers. $0 \mathrm{~m}$ de lengte en rotatie van het femur te bepalen moesten eerst een aantal landmarks in doorlichtingplaatjes van het proximale en distale fragment worden aangegeven. $0 \mathrm{~m}$ de waarden van het CAS systeem te evalueren werd gebruik gemaakt van een gouden standaard gebaseerd op een CT scan. De CAS rotatie en lengte werd vergeleken met de gouden standaard. De Inter-observer variabiliteit werd bepaald voor beide methoden.

Het verschil in lengtemeting tussen de CAS methode en de gouden standaard was $<1$ $\mathrm{cm}$. Het gemiddeld verschil in rotatie was $13^{\circ}\left(\max .26^{\circ}\right)$. CAS inter-observer variabiliteit bleek $5.5^{\circ}$ voor de rotatie en $5.2 \mathrm{~mm}$ voor lengte bepaling. Voor de gouden standaard was dit $3.1^{\circ}$ voor rotatie en $2.5 \mathrm{~mm}$ voor lengte meting.

Lengtemeting door het CAS systeem bleek accuraat en reproduceerbaar genoeg voor klinische toepassing. De CAS rotatiemetingen waren reproduceerbaar met een gemiddeld verschil van $5.5^{\circ}$ maar niet accuraat genoeg om malrotatie te voorkomen. Wellicht als het ongefractureerde been als voorbeeld wordt gebruikt voor de mate van rotatie kan het aantal postoperatieve malrotaties verkleind worden. Dit is het onderwerp van verdere studie.

Computer geassisteerde voorstekruisband positionering.

De meest kritische stap in arthroscopische reconstructie van een voorstekruisband (VKB) met een implantaat is positionering van de femur- en tibiatunnel, waar het implantaat in gefixeerd wordt. Een accurate positie van deze tunnels minimaliseert het uitrekken 
van het implantaat en vermindert de kans op inklemmen tussen het femur en de tibia. Wanneer aan deze voorwaarden is voldaan komt dat de levensduur en functie van het implantaat ten goede.

Met CAS is het mogelijk om tijdens de operatie de locatie van de femur- en tibia tunnel te definiëren. Hierna creëert het navigatiesysteem een model van de knie waarin de geplande positie van de "nieuwe" VKB virtueel is aangegeven. Tijdens het strekken en buigen van de knie wordt op een monitor het gedrag van deze geplande VKB gesimuleerd. 0p deze manier wordt de chirurg geïnformeerd over de mate van uitrekken en inklemmen van het implantaat. Nu wordt het mogelijk de ideale positie van de tunnels te bepalen.

Theoretisch zou virtuele planning de variatie tussen chirurgen moeten verkleinen wat weer zou leiden tot een grotere reproduceerbaarheid van deze procedure. In hoofdstuk 5 wordt deze hypothese getest in een kadaverstudie. Het verschil in planning tussen chirurgen werd berekend in $\mathrm{mm}$. Tevens werd de computer geassisteerde positie van de tunnels vergeleken met de positie van conventioneel geplande tunnels in dezelfde knie. Het gemiddeld verschil tussen de planningprocedures van verschillende chirurgen bleek 5 $\mathrm{mm}$ voor zowel de femur - als tibiatunnel. Het ervaringsniveau had hierop geen invloed. Het gemiddeld verschil tussen virtuele planning en conventionele planning bleek meer dan $6 \mathrm{~mm}$. Tijdens de conventionele planningprocedure trad er in 3 van de 12 knieën inklemmen op. In drie knieën werd een te grote uitrekking van het implantaat gezien. De minst ervaren chirurg bleek twee keer verantwoordelijk voor het inklemmen.

Deze studie laat zien dat computer geassisteerde planning het verschil in positionering van de tunnels reduceert tot $5 \mathrm{~mm}$. Het ervaringsniveau had hier geen invloed op. Onervaren chirurgen en chirurgen in opleiding zouden van dit systeem kunnen profiteren om het aantal adequaat gepositioneerde tunnels te optimaliseren.

\section{Zijn er klinische voordelen wanneer CAS gebruikt wordt voor het positioneren van implantaten?}

De resultaten gepresenteerd in hoofdstuk 3 mondden uit in de klinische implementatie van chirurgische navigatie bij het inbrengen van een Dynamic Hip Screw (DHS) bij mediale collum fracturen. Tevens werd in de kliniek de insertie van sacroiliacale (SI) schroeven met CAS vergeleken met de conventionele methode. 
Interne fixatie van mediale collum fracturen met CAS

Hoofdstuk 6 beschrijft onze ervaringen met CAS bij het inbrengen van een DHS in een kleine patiëntengroep. Zeven patiënten ondergingen een operatie. Allereerst werd het dynamische referentieframe gefixeerd met een Steinmanse pen. Bij vier patiënten werd de pen op de bekkenrand gefixeerd bij drie patiënten in het trochantor major.

Eerst werden een anterioposterior en lateraal röntgenbeeld van de heup in het navigatiesysteem (MediVision, Oberdorf, Zwitserland) geladen. Voor positionering van het DHS kanaal werd de virtuele positie van een $8 \mathrm{~mm}$ ongecannuleerde DHS boor geprojecteerd over deze beelden. Bij deze procedure werd er direct, zonder hulp van een K-draad geboord met een voor dit doel ontwikkeld $135^{\circ}$ richtapparaat. Na het genavigeerd boren van het kanaal werden de schroef en de plaat ingebracht volgens standaard techniek.

Eén CAS procedure werd voortijdig gestaakt omdat de virtuele positie van de boor duidelijk niet overeenkwam met de werkelijkheid. Dit was bij een patiënt waarbij het referentieframe in het bekken was gefixeerd. Het bleek dat ondanks het been in tractie was gebracht er geen rigide situatie bestond tussen het bekken en de te opereren heup. $\mathrm{Bij}$ de volgende procedures werd het referentieframe in het trochantor major gefixeerd.

Bij één patiënt bleek de schroef te diep te zijn ingebracht. In retrospectie bleek het door de matige kwaliteit van de röntgenbeelden, zichtbaar op het navigatiesysteem, niet goed mogelijk de contouren van de heupkop te zien. Tijdens de procedure bleek het lastig met één hand het $135^{\circ}$ richtapparaat vast te houden en tegelijkertijd te boren. Herhaaldelijk gleed de boor van het bot af. De afwezigheid van een K-draad werd hiervoor verantwoordelijk gehouden.

Onze beperkte ervaring liet zien dat het mogelijk is met CAS een DHS in te brengen, echter de beschreven techniek is te gecompliceerd voor de dagelijkse praktijk. Het navigeren van $\mathrm{K}$-draden kan de procedure meer intuïtief en daardoor eenvoudiger maken.

Insertie van sacroiliacale schroeven met CAS

In hoofdstuk 7 werd CAS vergeleken met conventionele chirurgie voor het positioneren van SI schroeven. In deze studie werd gebruik gemaakt van een navigatiesysteem wat navigatie van K-draden mogelijk maakt (Stealthstation iON, Medtronic SNT, Louisville,VS) De resultaten van de CAS groep werden vergeleken met die van een conventioneel geopereerde controlegroep. Eindpunten waren doorlichtingtijd, gemiddelde insertietijd voor de geleidedraden, operatietijd en het aantal complicaties. 
De studiegroep bestond uit 24 patiënten met post partum bekkeninstabiliteit. Alle patiënten werden gestabiliseerd door een anterieure plaatfixatie en een viertal SI schroeven. Uiteindelijk konden de resultaten van 48 versus 48 schroeffixaties met elkaar vergeleken worden. De conventioneel geopereerde patiënten werden intraoperatief van rug naar buikligging gedraaid. Alle CAS patiënten werden in rugligging geopereerd. Eén chirurg verrichtte alle operaties.

De doorlichtingtijd in de CAS groep was 0.7 minuten versus 1.8 minuten in de conventioneel geopereerde groep. De gemiddelde insertietijd voor vier K-draden was 20.2 minuten in the CAS versus 19.4 minuten in the conventioneel geopereerde groep. De gemiddelde operatietijd in de CAS groep was 97 minuten en 116 minuten in de conventioneel geopereerde groep. In de CAS groep had één patiënt pijn in het innervatie gebied van S2. Er bleek geen significant verschil in complicaties.

Deze studie liet zien dat CAS een veilige techniek is voor de insertie van SI- schroeven. De doorlichtingtijd werd verminderd met een factor 2.5. De langere operatietijd in de conventionele groep was te wijten aan het intraoperatief draaien van de patiënt. De insertietijd van de K-draden was gelijk in beide groepen maar het is te verwachten dat CAS in de toekomst de procedure zal versnellen.

\section{Conclusie}

De potentiële voordelen van CAS zijn duidelijk, een toegenomen nauwkeurigheid, veiligheid en reproduceerbaarheid bij chirurgische interventies. Dit proefschrift toont aan dat CAS op basis van röntgenbeelden accuraat genoeg is voor experimentele en klinische toepassingen. De positie van een chirurgisch instrument kan in $97 \%$ van de gevallen worden weergegeven met een foutmarge kleiner dan $2 \mathrm{~mm}$.

Echter wanneer deze techniek werd gebruikt voor een relatief simpele procedure als insertie van een DHS bleek dit toch technisch moeilijk uitvoerbaar met CAS. Verschillende technische aanpassingen waren nodig om navigatie in de heup mogelijk te maken. Het resultaat was een procedure die mogelijk was, maar niet rijp voor klinische implementatie. De onmogelijkheid om K-draden te navigeren leek hier debet aan te zijn.

Navigatie van K-draden resulteerde in een intuïtieve en gemakkelijk uit te voeren procedure, zoals bleek bij het genavigeerd inbrengen van SI-schroeven. Deze studie liet belangrijke voordelen van CAS zien. De doorlichtingtijd bleek een factor 2.5 kleiner vergeleken met de conventionele procedure. Verder is het is zeer aannemelijk dat CAS de procedure in de toekomst zal versnellen. 
De resultaten van onze experimentele studies laten zien dat het mogelijk is chirurgische variatie op een positieve manier te beïnvloeden. CAS kan worden gebruikt voor lengtecontrole bij de behandeling van femurschacht fracturen, echter de rotatiecontrole is nog niet volwassen genoeg voor de praktijk.

Het plannen van de insertieplaats van een VKB bleek een variatie van $5 \mathrm{~mm}$ te vertonen tussen chirurgen onderling. Of dit genoeg is om de operatieve resultaten te verbeteren is onderwerp van verdere studie.

Navigatiechirurgie zal in de toekomst standaard worden binnen bepaalde gebieden van de orthopedie en traumatologie. Deze gebieden zijn pedikelschroef plaatsing, SI-fixatie, reductie van pijpbeenfracturen en het plaatsen van knie- en heupprothesen. Navigatie binnen driedimensionale röntgenbeelden is onlangs geïntroduceerd en zal tot nieuwe implementaties leiden. 


\section{Dankwoord}


Vele mensen hebben de afgelopen tijd hun bijdrage geleverd aan de totstandkoming van dit proefschrift. Ik wil een ieder daarvoor hartelijk bedanken, maar een aantal mensen wil ik in het bijzonder noemen.

Lieve ouders,

Bedankt voor het vertrouwen dat jullie al op jonge leeftijd aan mij hebben gegeven. Ongelofelijk zoals jullie altijd interesse hebben in mijn dagelijks doen en laten. Ik weet dat ik altijd bij jullie terecht kan.

Prof. Dr. Chr. van der Werken,

Ik kon altijd stipt op uw analytisch vermogen en uw snelle correcties rekenen. Hartelijk dank voor de vrijheid, die u me hebt gegeven tijdens het onderzoek. Ik ben blij dat uw mijn promotor hebt willen zijn.

Dr. I.A.M.J. Broeders, beste Ivo,

Jij was het die me de gelegenheid bood me te gaan verdiepen in chirurgische navigatie. Tevens begeleidde je me tijdens mijn eerste stappen op het wetenschappelijke pad. Vele hoogtepunten zijn te noemen, het was een fantastische ervaring. Dank je.

Prof. Dr. A.B. van Vugt,

$U$ was het die me de beginselen van het vak bijbracht op negen midden. Later deelden we dezelfde interesse in chirurgische navigatietechnologie en werkten we samen voor het laatste artikel van mijn proefschrift.

Drs. J. Ruurda, beste Jelle,

We deelden een riante kamer in de catacomben van het Ziekenhuis. Het samen organiseren van de Skitrip, de lunches, Bu Cats waren hoogtepunten. Bedankt voor een geweldige tijd.

Dr. Van Walsum, beste Theo,

Dit boekje was er niet gekomen zonder jouw ondersteuning. Jij hebt me keer op keer verbaasd doen staan over je snelle en technische oplossingen voor problemen. Aan onze urenlange sessies in het skillslab en op de anatomie bewaar ik goede herinneringen. 
Alle overige medeauteurs,

M.H.J. Stavenuiter, C.H. Diekerhof, E.P.Martens, M.van Haeff, J.S. de Graaf, F.M. Kappelhoff.

Eelco de Graaf en Jasper Staring,

De allerbeste paranimfen, bedankt voor jullie hulp en inhoudelijke expertise tijdens deze periode. We kennen elkaar al zo lang en ik vind het geweldig dat ik jullie op zo'n dag aan mijn zijde heb staan.

Dr. E.J.M. Verleisdonk, beste Egbert,

Bedankt voor je hulp tijdens de klinische en experimentele studies. Zonder jou zou het niet mogelijk zijn geweest het experimentele in praktijk te brengen. Ons gezamenlijke TV optreden zal ik niet snel vergeten.

Drs. M.J.M. Seegers, beste Michiel,

Dank voor je hulp en expertise. Ik vond het altijd weer geweldig om samen met jou een procedure uit te voeren. Ik wens je alle geluk toe.

Drs. Haverlag, beste Robert,

Onze navigatie sessies zijn denk ik onnavolgbaar. Ik hoop dat we in de toekomst nog vele van dat soort sessies kunnen uitvoeren. Danke.

Hr. Swart, beste Jacob,

Gedurende de afgelopen jaren heb je me fantastisch geholpen met je technische ondersteuning, maar ook in de privesfeer doet het me altijd goed je te zien.

Mederwerkers van de 0KT,

Wiro, Shirley, Marloes, Tanja en Monique.

Medewerkers van de MTM,

E.J. Bakker, H.J. te Biesbeek, E. Duiveman, J.H. van Ewijk, C.D. van der Linden, C.J.S. Magielse

Bedankt voor jullie technische ondersteuning en originele oplossingen

Drs. Kazemier, beste Geert,

Bedankt voor je vertrouwen en de volgende keer in een echt restaurant. 
Mevr. Gellings, beste Carla,

Bedankt voor je hulp bij het tot stand brengen van dit boekje.

Dr. D.B.F. Saris, beste Daan,

Dank voor je hulp en betrokkenheid bij het artikel over de voorste kruisband module.

Dr. M.H.J. Verhofstad, Beste Michiel,

Onze tijd in het skillslab was geweldig leerzaam en gezellig. Bedankt voor je hulp.

Beste Karin en Edwin van de röntgen,

Jullie flexibiliteit heeft me altijd verbaasd doen staan. Zelfs het CT-scannen van varkens was voor jullie geen probleem.

Beste Willem en Simon van het anatomisch lab, wat een fantastisch team zijn jullie. Niets was teveel of te gek. Zonder de anatomie zou dit boekje er niet gekomen zijn.

Tot slot, lieve Anoukje,

Jij hebt een zeer grote bijdrage aan dit boekje geleverd door je grote hulp bij het printen, inbinden en drukken van dit proefschrift. Het leven met jou is mooi. Wat ben ik blij dat ik jou ben tegengekomen en samen met jou een nieuwe start heb gemaakt in Rotterdam. 


\section{Curriculum Vitae}

Niels Willem Luitzen Schep was born on January $22^{\text {th }}, 1972$ in IJsselstein, The Netherlands. After graduating from the Erasmiaans Gymnasium in Rotterdam in 1991, he attended medical school at the Faculty of Medicine of the University in Utrecht, The Netherlands. The degree of medicine was obtained in the spring of 1999. In 1999 and 2000 he worked as a surgical intern at the Department of General Surgery ( Prof. dr. H.J.Bonjer and Prof. dr. J. Jeekel) at the Erasmus Medical Centre in Rotterdam,The Netherlands. In December 2000 he was offered a research position at the Department of General Surgery of the University Medical Centre Utrecht by Prof. dr. Chr. van der Werken and dr. I.A.M.J. Broeders. In 2003 he started his training in Surgery at the Department of General Surgery at the Reinier de Graaf Gasthuis, Delft, The Netherlands (dr. L.P.S. Stassen). 
